Faculdade de Direito da Universidade de São Paulo.

Ísis Aparecida Conceição.

Os Limites dos Direitos Humanos Acríticos em face do Racismo Estrutural Brasileiro: O programa de Penas e Medidas Alternativas do Estado de São Paulo.

São Paulo

2009 


\title{
Faculdade de Direito da Universidade de São Paulo
}

\author{
Ísis Aparecida Conceição.
}

\section{Os Limites dos Direitos Humanos Acríticos em face do Racismo Estrutural Brasileiro: O programa de Penas e Medidas Alternativas do Estado de São Paulo.}

Dissertação apresentada à Faculdade de Direito da Universidade de São Paulo - USP, como requisito, parcial, exigido para a obtenção do título de mestre em Direito do Estado.

Professora Orientadora: $\operatorname{Prof}^{\mathrm{a}} \operatorname{Dr}^{\mathrm{a}}$. Eunice Aparecida de Jesus Prudente. 


\title{
Folha de Aprovação
}

\author{
Ísis Aparecida Conceição.
}

\section{Os Limites dos Direitos Humanos Acríticos em face do Racismo Estrutural Brasileiro: O programa de Penas e Medidas Alternativas do Estado de São Paulo.}

Dissertação apresentada à Faculdade de Direito da Universidade de São Paulo - USP como requisito parcial exigido para a obtenção do título de mestre em Direito do Estado.

Professora Orientadora: Prof Dr. Eunice Aparecida de Jesus Prudente.

Data de Aprovação:

Banca Examinadora:

Orientadora:

Membro :

Membro:

São Paulo

2009 


\section{Agradecimentos}

À minha orientadora, Eunice Aparecida de Jesus Prudente pela aposta e apoio.

À Minha Família, Cleusa, Inocêncio e Carlos, pelo apoio, amplo, irrestrito e incondicional, mas não cego.

Aos meus amigos/orientadores, isso não sairia sem vocês: Jean Manuel, Camila Kondilo, Ana Paula Andrade, Gabriel Swahili, Carlos Frederico, Carla, Andriana Lisboa, Bas'lele Malo Malo, Sandro, Miriam Diniz, Julio Xavier Galharte e Uvanderson, obrigada pelas críticas, pelas dicas, por colocarem ponto final nos meus parágrafos e tudo mais.

Aos colegas e irmãos de identidade, na USP, na UNESP, no NEINB, no NUPE, no IDDAB, na EDUCAFRO, e por ai vai... Obrigada.

Aos Funcionários do Departamento de Direito do Estado, da Pós Graduação e das Bibliotecas, em especial. E a todos da Faculdade de Direito e da Universidade de São Paulo. 


\section{Dedicatória}

Dedico à Minha avó, Geralda de Assis, que ensinou minha mãe que me ensinou a levantar, sacudir a poeira e dar a volta por cima. E dedico ao meu avô Benedito Conceição, que ensinou meu pai que me ensinou, ser bom e ser simples é garantia de Felicidade ! 
"Até que os leões tenham suas histórias, os contos de caça glorificarão sempre o caçador."

"A união do rebanho obriga o leão a ir dormir com fome."

(Proverbios Africanos) 


\section{RESUMO}

Esse trabalho teve como ponto de partida as raízes históricas dos Direitos Humanos com análise das vertentes ignoradas nos dias atuais. Apesar da moderna concepção e função entendida dos Direitos Humanos, ao observamos os efeitos das implementações de determinadas políticas públicas de Direitos Humanos em uma realidade Estruturalmente racializada, a exemplo da Brasileira, podemos constatar que os resultados dessas intervenções não interferem na segregação racial histórica que foi construída e ainda experimentamos no país, mas os perpetuam e até acentuam. A pergunta que se pretende responder é como se situam os Direitos Humanos na correlação de forças entre uma idéia de criação elitista, de origem burguesa para proteção de determinados grupos, e a necessidade atual, de utilização desses direitos como instrumento de uso efetivo das classes oprimidas.A análise dessa correlação de forças será feita sobre a observação da realidade brasileira através da análise crítica da literatura disponível sobre o assunto. Buscaremos uniformizar os conceitos sobre raça, racismo, preconceito, discriminação e outros mecanismos que explicam as dinâmicas das relações raciais no Brasil e no mundo. Apresenta-se a raiz da idéia de Direitos Humanos como eles foram inicialmente concebidos e como o são hoje em dia. Identifica-se essa raiz no conceito de Dignidade da Pessoa Humana e apresentamos como o racismo em suas diversas formas de manifestação nega esse direito, tornando-se, assim, uma ameaça para o Estado democrático de Direito, que tem como elemento fundador e legitimador a dignidade humana. E feito um levantamento histórico de formação da idéia de controle social no Brasil, as origens teóricas da idéia que estruturou o nosso sistema criminal, as suas bases racistas e como esses elementos de origem refletem-se nos dados de desigual acesso ao sistema de justiça criminal até os dias atuais. A seletividade é tratada como um elemento constituinte e pouco considerado do sistema de controle social moderno. A Dissertação é finalizada com uma análise dos dados referentes à política penitenciária do Estado de São Paulo e os reflexos que uma estrutural racializada, do sistema de controle social brasileiro, implica na implementação desigual, racialmente falando, do programa de penas alternativas.

Palavras Chaves: Racismo Estrutural, Racismo Institucional, Direitos Humanos, Teoria Crítica, Penas Alternativas, Direitos Humanos. 


\begin{abstract}
This paper had as point of departure the historical roots of Human Rights, with the analysis of aspects still ignored at present days. Despite the understanding of the modern conception and function of Human Rights, when one observes the effects of the implementation of certain public policies in a society racially structured, as the Brazilian society, it is possible to note that the results of these public policies do not intervene in the historical racial segregation that was developed and still experimented in the country. The question to be answered is how Human Rights, having its roots based on the elites and conceived to protect certain groups, can really be effective as an instrument to serve the oppressed groups. The analysis of this correlation of forces on Human Rights will be made over the observation of the Brazilian reality and through the critical analysis of the available literature on the subject. We will seek to standardize the concepts about race, racism, prejudice, discrimination and other mechanisms that explain the dynamics of the racial relations in Brazil and in the World. The root of the Human Rights idea is presented, as it was initially conceived and as it is now. Within the concept of Human Dignity we present how racism in its various forms denies this right, becoming then, a menace to the Democratic State of Rights, which has as founding element the human dignity. A historical research is made, about the formation of social control in Brazil, and the theoretical origins of the ideas that structured our criminal system and its racist bases and how these elements of origin reflect on the unequal access to the criminal justice system, nowadays. The selectivity is treated as a constitutive element and less regarded in the modern social control system. The paper is finished with an analysis of the data concerning the penitentiary policy of the State of São Paulo and the reflexes that a racially structured society can have on the Brazilian system of social control, precisely on the program of alternative penalties.
\end{abstract}

Keywords: Structural Racism, Institutional Racism, Human Rights, Critical Theory. Alternative Penalties. 


\section{SUMÁRIO}

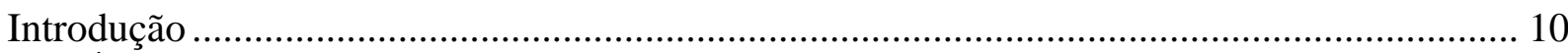

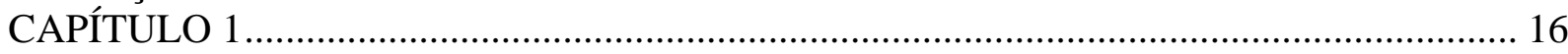

1.- Definição dos conceitos de raça, racismo, preconceito, branquidade e discriminação

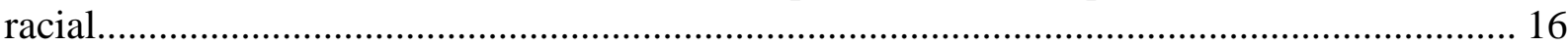

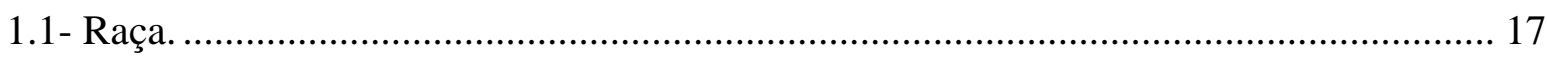

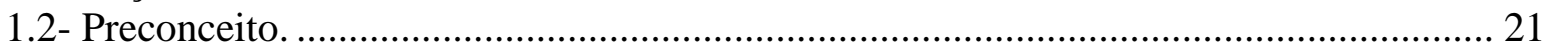

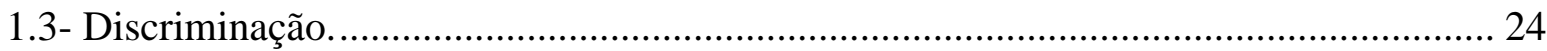

1.4 - branquidade, privilégio branco e cumplicidade branca. .............................................. 24

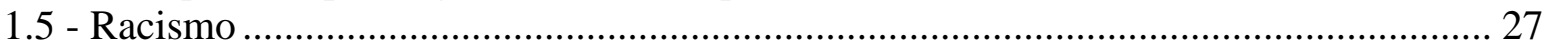

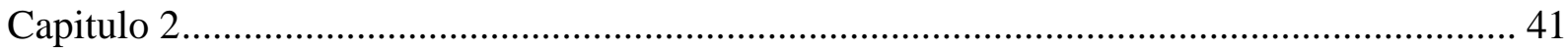

2.0 - Dignidade da pessoa humana e racismo no Estado Democrático brasileiro. .................... 41

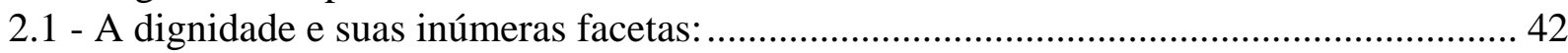

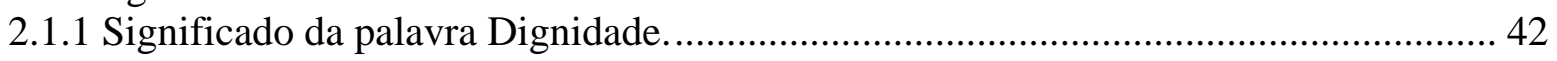

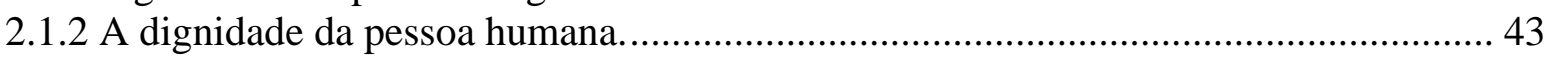

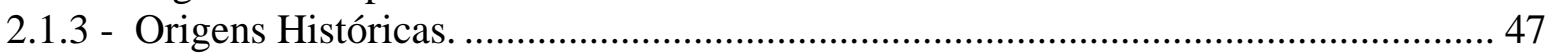

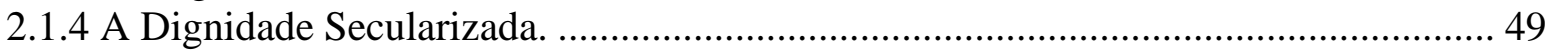

2.1.5 A dignidade em toda sua amplitude Comtemporânea. ............................................... 53

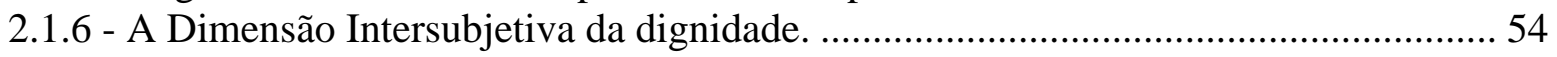

2.1.7 Uma aproximação de um conceito normativo de Dignidade...................................... 56

2.1.8- A proteção da dignidade como dever e fundamento do Estado ................................. 58

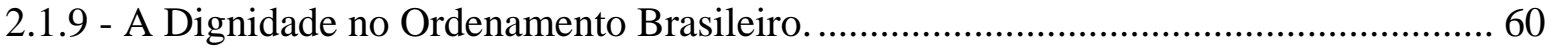

2.1.10 - A Dignidade como fundamento do Estado Democrático...................................... 61

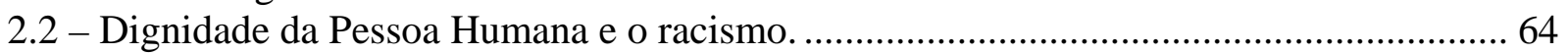

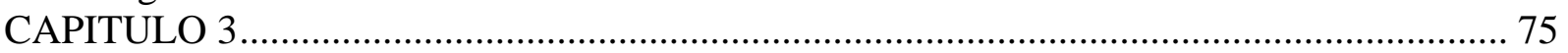

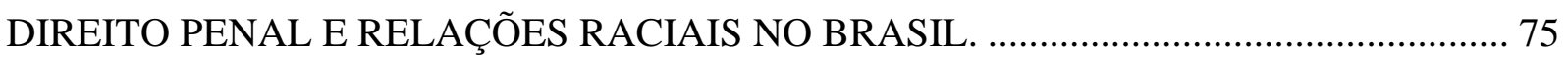

3.1. Realidade racial brasileira e a recepção e incorporação das teorias criminológicas

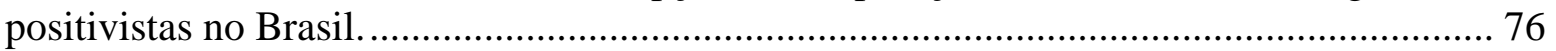

3.1.1- Contexto de recepção das teorias criminológicas no Brasil.................76

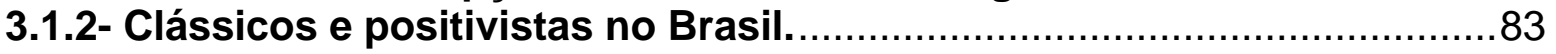

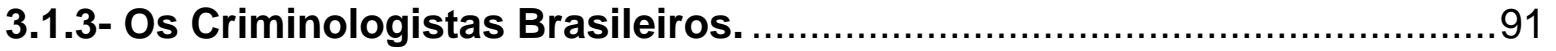

3.2. Efeitos da "retomada" destas teorias no Brasil. Tendência Político Criminal

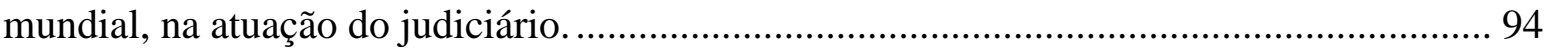

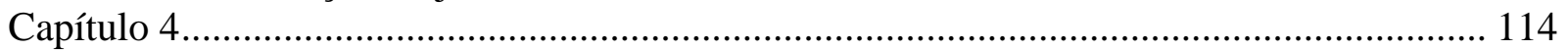

Direitos Humanos Acríticos e Racismo Estrutural no Brasil os dados sobre o programa de

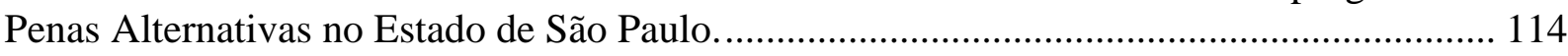

4.1 Teoria Crítica dos Direitos Humanos. ............................................................................. 115

4.2 Panorama do Sistema Carcerário do Estado de São Paulo. .......................................... 122

4.3 O Programa de Penas Alternativas e suas incongruências Raciais................................ 125

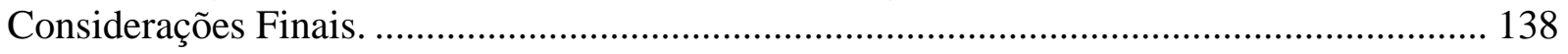

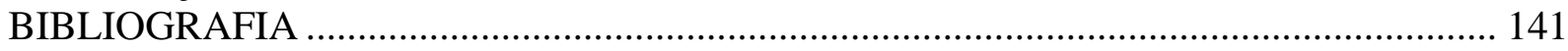




\section{Introdução}

Direitos Humanos para Humanos Direitos. A máxima popular dos contrários aos assim chamados pejorativamente de "Direitos dos bandidos", não é tão original, moderna e brasileira como os programas policialescos de televisão, que passam à tarde, faz com que acreditemos.

Em verdade, a natureza desta máxima, de que nem todos fazem jus ao gozo dos Direitos inerentes a condição humana, fundados na dignidade, é seminal na construção destes Direitos e reflete-se nas sua aplicação até os dias atuais.

Em sua obra "A afirmação histórica dos direitos humanos", o Professor Comparato pontua que, no embrião dos Direitos Humanos, A Magna Carta de 1215 despontou o valor da liberdade. Liberdade essa específica, em favor, principalmente, dos estamentos superiores da sociedade (COMPARATO, 2005, p.45). As liberdades pessoais declaradas pelo Hábeas Corpus e pelo Bill of Rights não beneficiavam indistintamente todos os súditos, mas preferencialmente os dois primeiros estamentos, o clero e a nobreza. (COMPARATO, 2005, p.48).

Assim como outros autores, o professor aponta que os Direitos Humanos não provêm do objetivo de tornarem-se instrumentos de proteção da maioria pobre contra as condições indignas de vida a que eram submetidas, mas sim, têm sua origem nos instrumentos de proteção das elites em face dos desmandos do rei. A burguesia aproveitou-se desses instrumentos, apesar de não ser neste momento o grupo beneficiário previsto.

Populações alijadas do direito de cidadania desde as origens da idéia de cidadão, ainda não possuem os requisitos que fundamentaram a construção 
inicial desse valor, a propriedade, afinal, nas origens desses discursos de direitos iguais à participação nas decisões do Estado e de autodeterminação da existência humana, existia a separação entre direitos econômicos sociais e direitos políticos de uma forma muito mais intensa e não questionada.

Então, historicamente, podemos dizer que os primeiros documentos de Direitos Humanos foram cartas declaradas por grupos, que não eram exatamente os menos privilegiados das ordens sociais onde estas foram declaradas. No caso, os burgueses buscavam apenas garantir o regular exercício de Direitos que lhes eram negados pelos nobres e pelo rei, fundamentando-os na propriedade.

Em tese, a submissão do Rei/Estado às normas de conduta que respeita a dignidade humana foi uma revolução, mas uma revolução proposta por um grupo para si e não para todos indistintamente.

Temos, assim, como pressuposto, que os Direitos Humanos não apresentam uma origem universalizante, de direito de dignidade igual para todos, mas sim de garantia do exercício de alguns direitos relacionados à condição de classe emergente, da burguesia, em face do despotismo de um rei que não possuía limites em suas arbitrariedades cerceadoras do exercício regular dos direitos deste grupo oprimido.

Partindo dessas raízes históricas dos Direitos Humanos, quase sempre ignoradas, e das suas funções e dos objetivos declarados nos dias atuais, de direitos compreendidos como de necessário alcance a todos e que têm por função resguardar uma base mínima de garantias a uma vida digna, perguntamos: como se situam os Direitos Humanos na correlação de forças entre uma idéia de criação elitista e origem burguesa para proteção desses grupos, e a necessidade atual de utilização desses direitos como instrumento de uso efetivo das classes oprimidas para sua defesa e luta na conquista dos direitos garantidores de suas dignidades? Como essa correlação pode ser observada no Brasil?

Como essa aparente contradição entre os objetivos de origem e as atuais funções desses Direitos, somada à realidade prática dos países do Sul Global, podem implicar em uma contradição entre a proposta destes Estados em tornarem-se Estados Democráticos de Direito, e o não comprometimento com a eficaz aplicação dos compromissos internacionais assumidos para proteção igual da dignidade humana de todos os membros da Sociedade. 
Com a normatização e maior teorização sobre os Direitos Humanos, encaramos inúmeros impasses entre a sua origem prática e a sua idealização teórica moderna. Em tese, tais instrumentos hoje são legitimados como mecanismos de proteção dos oprimidos socialmente, em face de uma organização social global desumana e excludente, bem como das arbitrariedades estatais e negadoras do exercício de direitos garantidores de uma vida digna.

Como pensar que determinadas populações índios, negros, agricultores, analfabetos hoje organizados em movimentos sociais, alijados da cidadania desde a sua origem, grega ou moderna, poderão alcançá-la? Se esse valor está pautado, em suas origens, mais na propriedade privada do que na dignidade humana?

Apesar da moderna concepção e função entendida dos direitos humanos, ao observamos os efeitos das implementações de determinadas políticas públicas de Direitos humanos em uma realidade estruturalmente racializada, a exemplo da brasileira, podemos constatar que os resultados dessas intervenções não interferem na segregação racial histórica, que ainda experimentamos no país, mas os perpetuam e até acentuam.

Podemos perceber, a exemplo dos efeitos das políticas Estatais na área de educação conforme os dados apresentados pelo IPEA, que políticas universalistas em realidades estruturalmente multiculturais e excludentes mantêm essa exclusão quando não as acentuam.

Num exemplo: apesar da ampliação do acesso ao ensino superior, o número de jovens brasileiros que acessam o ensino superior nos últimos anos mais que triplicou, o vale que distancia negros e brancos desse acesso permanece inalterado. Em 1995, 9,2\% dos universitários eram brancos e 2\% eram negros; em 2005 esses números alteraram-se sendo que 19\% dos universitários eram brancos e 6,6\% desses eram negros. (Fonte:IPEA)

É possível perceber até um maior distanciamento entre brancos e negros, o que pode indicar que políticas universalistas na Educação beneficiaram muito mais intensamente jovens brancos no acesso ao ensino superior do que jovens negros.

Outros espaços de intervenção Estatal com políticas públicas de inclusão ou de redução de exclusão sem a devida atenção para a nossa constituição multicultural nacional parecem manter essas desigualdades, a exemplo do 
Sistema da Saúde, conforme os dados disponibilizados pelo Programa das Nações Unidas para o Desenvolvimento (PNUD) em sua pesquisa sobre Racismo Institucional na Saúde.

A partir dessas ponderações, indagamos por que o sistema criminal seria diferente? Por que as intervenções pautadas em recomendações de Direitos Humanos, internacionais, aplicadas, ignorando a constituição nacional multicultural, em espaços estruturalmente racializados, como a Educação, a Saúde e o Sistema Prisional, teriam um resultado de alteração do vale racial entre brancos e negros?

Durante a formação do projeto de Estado Brasileiro, a exclusão negra foi um elemento explicitamente presente. A fundação da nova sociedade teve, declaradamente, em alguns momentos, e não declaradamente, em outros, um projeto de eliminação dos traços inoportunos resultantes da presença da ex-mão de obra que não mais podia ser utilizada como escrava e, por isso, apresentavase como um inconveniente não mais útil ou necessário para a sociedade que se projetava.

O Estado brasileiro, através do Instituto de Pesquisa Econômica Aplicada (IPEA), dentre outros órgãos, assume frontalmente a existência de um grave problema social, afirma que esse problema estabelece desvantagens material e social às suas vítimas; e que tem raízes no passado e incide, também, no presente. Esse problema é a discriminação contra o negro, naturalizada no período da escravidão, estruturada durante a formação do Estado brasileiro e mantida nas interações sociais cotidianas em inúmeros espaços até os dias atuais.

O professor Joaquim Herrera observa, em suas obras, que os Direitos Humanos não podem ser teorizados e aplicados sem considerar uma teoria do impuro, pautada nos seguintes elementos: espaço, contexto, posição, vínculos, pluralidade, diferença, disposição, conteúdos, relatos, história, narração, temporalidade e mobilidade. (HERRERA, 2000, p.33).

Dessa forma, seria, o programa de penas alternativas uma proposta de Direitos Humanos que não conseguiu passar ileso pela estrutura nacional? Estaria correndo também esse programa o risco de ser aplicado de forma viciada, a partir dos valores constituintes nacionais, o que implicaria em um 
desvirtuamento do programa, fazendo dele mais um espaço de reprodução das viciadas relações sociais brasileiras?

A desconstrução crítica da idéia de criminalidade, apresentou o conceito de criminalidade do colarinho branco, ou seja, o crime como regra e não como exceção. Haveria a necessidade legitimadora de que o sistema penal alcançasse os grupos que antes não eram alcançados; a função de seletividade explicitada precisou ser desconstruída. O aumento do número de indivíduos alcançados pelas penas colocou em evidência a realidade carcerária, espaços onde antes somente os selecionados socialmente conheciam.

A possibilidade de que grupos antes não alcançados pelo sistema penal tivessem que ser submetidos à estrutura carcerária desumana de um país que a construiu para indivíduos encarados como não humanos e, conseqüentemente, não dignos encontrou na aplicação de medidas alternativas à pena de reclusão uma possibilidade de legitimação do sistema, reduzindo a sua explícita função seletiva que se apresentava durante e persecução penal e empurrando essa função seletiva agora para outro espaço: a aplicação da pena.

Seria, assim, o programa de medidas alternativas à pena de prisão uma política de redução da superpopulação carcerária, que terminou por ser manipulada dentro da lógica histórica, social e econômica local do Brasil?

Nessa dissertação, buscaremos, a princípio, uniformizar conceitos sobre raça, racismo, preconceito, discriminação e outros mecanismos que explicam as dinâmicas das relações raciais no Brasil e no mundo. Esses são os objetivos do capítulo primeiro.

No segundo capítulo, apresentaremos a raiz da idéia de Direitos Humanos como são concebidos hoje em dia. Identificamos essa raiz no conceito de dignidade da pessoa humana. Também apontaremos como o racismo em suas diversas formas de manifestação nega esse Direito, tornando-se, assim, uma ameaça para o Estado Democrático de Direito, que tem como elemento fundador e legitimador a dignidade humana.

No terceiro capítulo, trazemos um histórico de formação da idéia de controle social no Brasil, as origens teóricas da idéia que estruturou o nosso sistema criminal, as suas bases racistas e como esses elementos de origem refletem-se nos dados de desigual acesso ao sistema de justiça criminal até os 
dias atuais. Nesse capítulo, também, traremos a seletividade como um elemento constituinte e pouco considerado do sistema de controle social moderno.

O quarto e último capítulo analisa os dados referentes à política penitenciária nacional e os reflexos que a construção estrutural racializada do sistema de controle social brasileiro tem na implementação desigual, racialmente falando, do programa de penas alternativas que tem por objeto reduzir os índices de encarceramento, conforme recomendação da Organização das Nações Unidas (ONU).

Nesse contexto, ignorar os elementos de uma teoria crítica de Direitos Humanos para aplicação dessas recomendações termina por torná-los material manipulado que apresenta resultados aparentemente positivos, mas não consegue atingir estruturalmente a lógica da instituição de controle social e torna se mais um instrumento de pseudo inclusão e manutenção dos privilégios historicamente construídos na sociedade brasileira. 


\section{CAPÍTULO 1}

\section{1.- Definição dos conceitos de raça, racismo, preconceito, branquidade e discriminação racial.}

Nas inúmeras propostas de debate sobre o racismo, um dos problemas com que se deparam seus pesquisadores é a confusão conceitual que envolve o tema. Essa confusão é resultante, dentre outros motivos, da ampliação do número de publicações não especializadas sobre a questão, tão em voga no momento, que utilizam, de forma aleatória, alguns conceitos. No entanto, há grande quantidade de publicações existentes com definições precisas e similares, não só no Brasil como no mundo todo.

Poderíamos, no desenvolvimento desta dissertação, partir do pressuposto de que é do conhecimento de todos a existência, no Brasil, do racismo e da natureza deste. Contudo, o que aponta o discurso do senso comum e até mesmo científico formal/oficial é que o brasileiro não apresenta preconceitos, sendo o Brasil uma ilha de democracia racial. Em razão desse constatado discurso, optamos por fazer primeiramente algumas reflexões em torno da natureza do racismo e das relações raciais no Brasil, bem como das características que os tornam tão peculiares, únicos e de tão difícil combate nos vários palcos de desenvolvimento das relações sociais dos brasileiros.

A proposta deste trabalho não é a de discutir se existe ou não discriminação racial no Brasil. Acreditamos ser este um fato já dado ${ }^{1}$. Interessa nos, aqui, apreendermos uma outra esfera dos estudos das relações raciais no

${ }^{1}$ Conforme SANTOS, (2001, p.37) "não legisla-se sobre o abstrato ou intangível, a nossa Constituição federal prevê a não discriminação e o repúdio ao racismo além da imprescritibilidade deste crime". O Estado brasileiro assumiu o compromisso de implementação de políticas de combate ao Racismo Institucional na Saúde e Educação, reconhecendo que os dados estatísticos que denunciaram, durante pelo menos as últimas três décadas, a desigual realidade brasileira é amplamente conhecida e, portanto, de necessária intervenção por intermédio de políticas públicas específicas. 
país, qual seja, a de dar visibilidade ao fenômeno sistematizando informações de forma a viabilizar essa visibilidade.

Justificaremos as opções terminológicas aqui empregadas propiciando um rigor na definição de determinados conceitos a fim de que o debate seja travado de forma precisa. Sem tal elucidação não se pode determinar o que se está analisando ou valorando, já que a forma como definimos um problema social influencia no modo como concebemos possíveis intervenções com o fim de eliminá-lo.

\section{1- Raça.}

Em 1684, o francês François Bernier em sua obra, Nouvelle division de la terre par les différentes espèces ou races qui l'habitent, emprega o termo no sentido moderno da palavra, para classificar a diversidade humana em grupos fisicamente contrastados. (KABENGUELE, 2004, p.15).

Em 1758, o botânico sueco Carl Von Linné ou Carolus Linnaeus - criador do atual sistema de classificação dos seres vivos - deu à humanidade o nome científico de Homo sapiens e a dividiu em quatro subespécies: os vermelhos americanos, "geniosos, despreocupados e livres"; os amarelos asiáticos, "severos e ambiciosos"; os negros africanos, "ardilosos e irrefletidos", e os brancos europeus, "ativos, inteligentes e engenhosos". Assim, diante dessa noção de que dentro da espécie humana existiriam raças, surge também a idéia do valor de cada uma em relação a outra. Etimologicamente, a palavra raça é um termo de origem italiana, "razza", a sua raiz latina já trazia a idéia de espécies, tipos.

O conceito de raça tem evoluído com a história da humanidade. Se como se viu em 1758, Lineu considerou todos os homens pertencentes a uma única espécie, o Homo sapiens,. Charles Darwin criou a teoria da "evolução" das espécies e indicou três fases da evolução do homem, originada nos símios: 
"Homem Primitivo", "Homem Selvagem" e "Homem Civilizado" (nesta última encontrar-se-ia somente os europeus). ${ }^{2}$

Inicialmente, identificamos raça como um conceito das ciências biológicas, utilizado para designar um conjunto de aspectos que diferenciam elementos de uma mesma espécie. No século XIX, as teorias raciais sustentaram diversas ideologias nacionais e nacionalistas, uma vez que tais teorias correlacionavam, rigidamente, patrimônio genético a aptidões intelectuais e inclinações morais. Essa transferência do termo do reino da biologia/zoologia para o âmbito das relações sociais serviu para legitimar dominações e, já nas décadas de 20 e 30 do século $X X$, o conceito de raça, largamente utilizado, resultou em experiências degradantes historicamente notórias. Como conseqüência desse nocivo uso, a reação dos cientistas passou a ser a de renegar o conceito aplicado entre humanos.

Um estudo realizado nos anos 50 pela Organização das Nações UnidasONU, desenvolvido por geneticistas, antropólogos, cientistas sociais, biólogos e biofisiologistas, apontou a inaplicabilidade do termo raça, cientificamente falando, entre os seres humanos ${ }^{3}$. Esse estudo concluiu que a espécie humana apresenta variações de aparência (decorrentes de necessidades orgânicas, como a proteção dos raios solares e dos inúmeros cruzamentos entre grupos) que em nada afetam a possibilidade de convivência e reprodução entre os membros desta espécie.

Apontado como um dos conceitos mais contraditórios em antropologia biológica, a definição de raça, segundo Adelino Brandão (2002, p.19), peca fundamentalmente contra a lógica, uma vez que de acordo com a Biologia, o conceito não tem valor operacional. Para d'Adesky (citado por BRANDÃO, 2002), no atual estágio da ciência, nada autoriza a exata delimitação das raças, sendo que até hoje os critérios raciais não puderam ser definidos, pois eles não são invariáveis.

\footnotetext{
${ }^{2}$ MARINHO, 1999, passim

${ }^{3}$ Essa afirmação foi feita pelo bioquímico geneticista francês François Jacob, ganhador do Prêmio Nobel de Fisiologia de 1965 pela descoberta, juntamente com outros colegas, do RNA mensageiro.
} 
Nesse estágio, a dimensão de raça ultrapassou a pigmentação da pele e só pôde ser compreendida num plano cultural, um contexto tenso no qual um ideário anti-racista - que negava a existência biológica de raças - e uma ideologia - que negava a existência do racismo e da discriminação racial, insuportável para todos e insustentável pelos fatos - fizeram surgir a necessidade de teorizar "raça" como o que ela é, ou seja, uma construção baseada em concepções cientificamente errôneas, mas socialmente eficientes: "Se as raças não existem num sentido estritamente realista de ciência, ou seja, se não são um fato no mundo físico, são, contudo, plenamente existentes no mundo social" (GUIMARÃES, 1999, p.153). De acordo com este sociólogo, "os brasileiros acreditam em raças e agem de acordo com elas. Então, elas existem". antropólogo Kabengele Munanga (KENSKI, 2004, p.45) vê raça como "uma categoria de exclusão e dominação que traz problemas na realidade". "Mesmo que não existam biologicamente, elas criam vítimas", afirma ele. Podemos então deduzir que, ao menos na cabeça das pessoas, as raças são bem reais.

Ainda nesse debate, o professor Carlos Moore complementa:

"Raça é um conceito, uma construção, que tem sido às vezes definida segundo critérios biológicos. Os avanços da ciência nos últimos cinqüenta anos do século $X X$ clarificaram um grave equívoco oriundo do século XIX, que fundamenta 0 conceito de "raça" na biologia. Porém, raça existe: ela é uma construção sociopolítica, o que não é o caso do racismo. Racismo é um fenômeno eminentemente não conceitual; ele deriva de fatos históricos concretos ligados a conflitos reais ocorridos na História dos povos".(2007, p.23).

De forma bem eloqüente, o professor Antonio Sergio Alfredo Guimarães exemplifica como esse conceito pode fazer parte das nossas relações cotidianas encarado como verdade absoluta, apesar da desconstrução científica de sua aplicação biológica à espécie humana: 
"Assim como aceitamos, há séculos, a teoria copernicana sem que deixássemos de organizar as nossas experiências diárias em torno da crença de que o sol se põe e se levanta, assim também acontece com a crença em "raças". Continuamos a nos classificar em raças, independente do que nos diga a genética. Pragmaticamente, portanto, as pessoas que adotam tal postura anti-racista, também não acreditam em raças biológicas, mas aceitam que as raças sociais são construções permanentes, sobre as quais deve-se organizar a luta anti-racista". (GUIMARÃES, 2002, p.52).

Em termos biológicos, é consensual hoje afirmar que as raças humanas realmente inexistem e que algumas doenças, que teoricamente são comuns a um grupo racial, seriam mais corretamente apontadas como enfermidades próprias a um mesmo grupo ancestral, uma vez que a diferença genética entre dois europeus pode ser maior do que a diferença genética entre esse mesmo europeu e um africano ${ }^{4}$. Contemporaneamente, o conceito de raça não possui mais utilidade biológica.

Esta realidade constatada trouxe a presença de um ideário, segundo Antônio Sérgio Guimarães, "anti-racialista", de negação total e incondicional da idéia de existência de "raças", que se fundiu rapidamente com uma política de negação do racismo como fenômeno social. Entre nós brasileiros existiria apenas o "preconceito", ou seja, percepções individuais equivocadas, que tenderiam a ser corrigidas na continuidade das relações sociais. (GUIMARÃES, 1999, p.148-49).

No entanto permanece relevante em âmbitos como o da Antropologia, Sociologia e mesmo do Direito, com a função de identificar as diferenças fundadas na valoração das pessoas em função da cor da pele e dos traços fenotípicos (racialismo); valoração esta que gera conseqüências de relevância concreta nas interações cotidianas do dia-a-dia.

Raça, assim, apresenta-se como única categoria para pessoas cujas identidades têm que ser construídas sobre identidades socialmente forjadas,

\footnotetext{
${ }^{4}$ Mesmo que a raça seja um recurso útil para prever o risco de doenças, muitos médicos acreditam que seria melhor abandoná-la em prol de uma análise mais rigorosa da ascendência: "Não se sabe ao certo se usar raças na medicina é melhor do que não usar nenhuma informação sobre ancestralidade. A única semelhança, por exemplo, entre os negros do Sri Lanka, da Nigéria e do norte da Austrália é a cor da pele. (Kenski, 2004, p.45).
} 
única categoria possível de auto-identificação, categoria imposta pelos opressores, enquanto existirem grupos identificados por marcadores ligados à idéia de raça esse conceito sociologicamente presente tem que ser encarado como realidade a fim de viabilizar uma intervenção anti-racista.

\section{2- Preconceito.}

A palavra preconceito vem de pré-conceito, julgamento antecipado, isto é, a formação de uma opinião sem avaliação prévia dos dados e fatos. Não há uma compreensão responsável sobre os efeitos e resultados deste julgamento préconcebido. Categoria pertencente à Psicologia, invariavelmente é dirigida contra alguém. Um elemento de contribuição para a difusão do preconceito são os chamados "estereótipos" ou clichês, chavões que são continuamente repetidos sem questionamentos ou reflexão.

O estereótipo provém de uma generalização de conceitos sem avaliações pormenorizadas, atribuindo a todo um grupo comportamentos observados em uma só pessoa ("todo judeu é sovina. Túlio é judeu, logo Túlio é sovina"). Assim, há uma tendencia a desconsiderar a individualidade das pessoas, atribuindo a priori aos membros de determinado grupo características estigmatizantes com as quais o grupo, e não o indivíduo, é caracterizado.

Essa falsa idéia, o preconceito, a misrecognition vai muito além da falta de respeito. O preconceito pode provocar feridas graves, impondo a suas vítimas um ódio de si mesmas (self hared, que é mais do que falta de amor-próprio) que as aleija.( TAYLOR, apud LOPES, 2000, p.95).

Dessa forma, Hédio Silva assegura que: 
"Assim, os componentes básicos do preconceito pressupõem um sistema social no qual a etiqueta racial possua relevância na distribuição dos lugares sociais, da mesma forma que um tal sistema social pressupõe agentes que operem as desigualdades raciais do sistema." (2000, p.22)

Dentre as características do preconceito, podemos apontar as que se seguem e pressupõem um sistema social. São elas:

- $\quad$ Um sentimento de superioridade;

- $\quad$ Percepção da raça subalternizada como intrinsecamente diferente e estrangeira;

- Uma pretensão à propriedade de certas áreas da convivência humana e privilégios;

- Medo e suspeita de que a raça subalternizada aspire às prerrogativas sociais e/ou econômicas, etc. da raça dominante ${ }^{5}$.

Vale, por fim, assinalar, conforme nos ensina Silva ${ }^{6}$, que o Direito, via de regra, não pune a mera cogitação - cogitationis poenam nemo patitur - como demonstrado no gráfico (fig. 1).

\footnotetext{
${ }^{5}$ Apud SILVA, H. Op. cit., p.22.

6 Esquema apresentado pelo professor e advogado Hédio Silva Jr em mini-curso sobre a discriminação racial e direito, ministrado no II Congresso Brasileiro de Pesquisadores Negros realizado na cidade de São Carlos em setembro de 2002.
} 


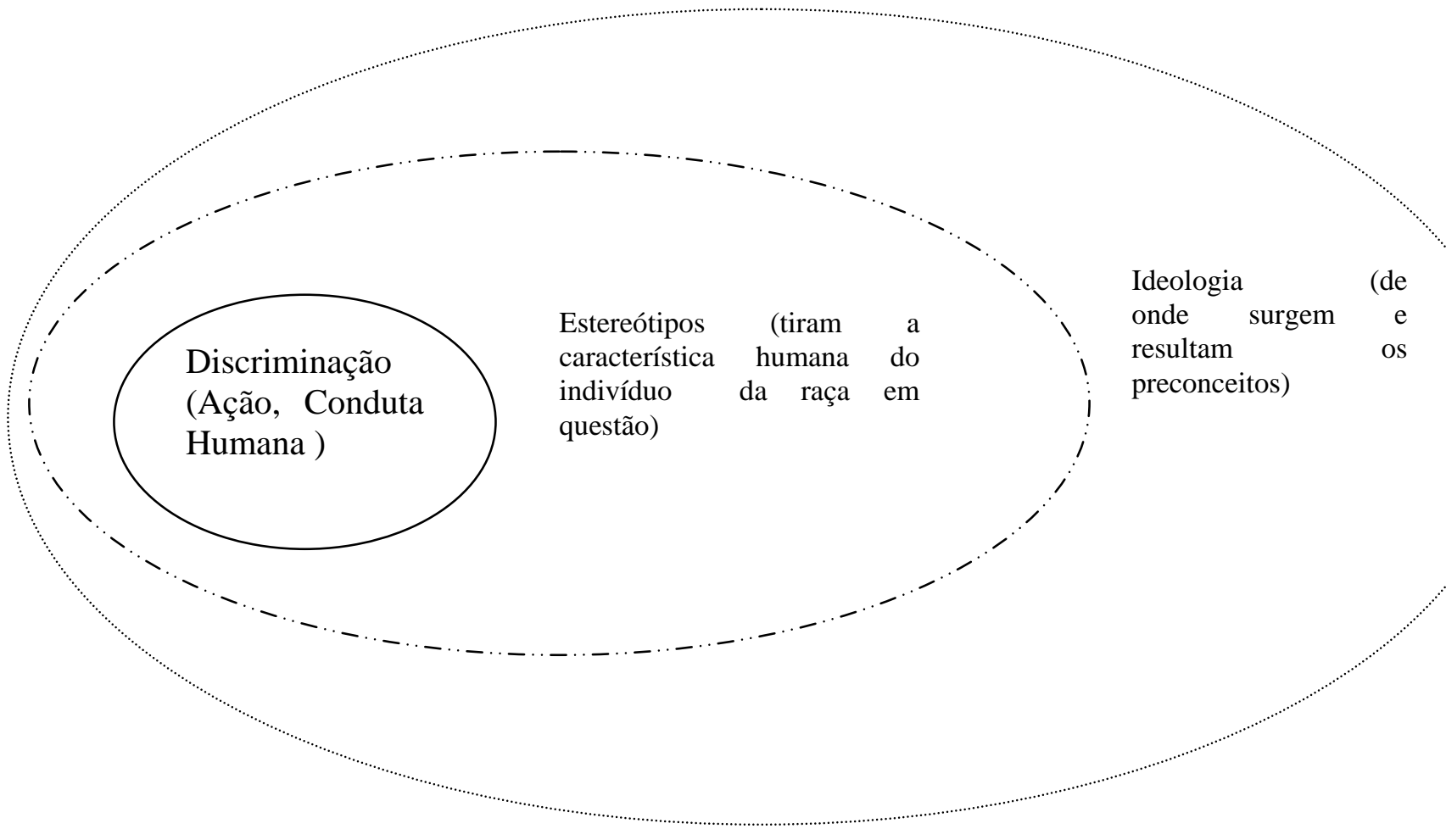

Conduta humana na qual o direito deve intervir.

Conduta humana em que o direito não consegue intervir.

Seara da liberdade interna na qual o direito não consegue e não deve intervir.

É por este motivo que, apesar de a nossa Carta Magna proibir formalmente o preconceito, este, por se enquadrar no âmbito do que é de foro íntimo, não é suscetível de sanção penal ou mesmo cível, cabendo combatê-lo em outro âmbito que não o penal, como por meio de políticas públicas, por exemplo. Políticas que reconheçam e valorizem as culturas e os grupos que são vítimas dessas disposições afetivas imaginárias que incidem sobre indivíduos ou grupo de indivíduos. No entanto não podemos ignorar a sua relevância no debate atual sobre o racismo estrutural uma vez que os já constatados fatores que implicam nas desigualdades entre grupos raciais na sociedade brasileira não determinam sozinhos a profundidade e o escopo dessas desigualdades. Em áreas que vão do 
emprego à moradia, o preconceito permanece como um contribuinte ativo e poderoso para as desigualdades raciais e, conseqüentemente para o racismo.

\section{3- Discriminação.}

A discriminação é uma prática difundida e amparada pelos pré-conceitos e pelas teorias racistas. Discriminar é identificar diferenças e, a partir delas, distinguir, afastar. No ato de discriminação há um objetivo de separação, de tratamento diferenciado. A discriminação racial compreende a separação daqueles que têm raças diferentes, que pertencem a grupos étnicos diversos. $\mathrm{Na}$ discriminação há uma atitude concreta, através da aplicação prática, fundamentada dos valores e pré-conceitos informados pelas teorias racistas.

É importante enfatizar que a discriminação é constituída de uma atitude, positiva ou negativa, de alguém contra outrem em razão de suas "diferenças", sejam elas raciais, sociais, econômicas, religiosas, etc. A discriminação racialnegativa é resultante da teoria racista, da aplicação, na prática, de uma agressão que visa manter ou criar o afastamento da outra raça, segregá-la. Apesar de ter relação com o preconceito, a discriminação nem sempre guarda uma relação de causa e efeito com o preconceito, consistindo, antes, em um ato, uma conduta disciplinada pelo sistema jurídico brasileiro (Art. I, item1, da Convenção Internacional sobre Eliminação de Todas as Formas de Discriminação Racial).

1.4 - branquidade, privilégio branco e cumplicidade branca.

Interrogar a branquidade e o privilégio branco é tendência recente na academia brasileira. Apesar de Du Bois, Ralph Elison e James Baldwin, é Macintosh (1988, p. 70) o autor identificado como iniciador esse debate sobre a 
relevância de se compreender a identidade do branco, assim como a do negro. Assim, ele trouxe ao público o conceito de Branquidade e, para tanto, elaborou uma lista com cinqüenta privilégios passíveis de serem desfrutados por uma pessoa em uma sociedade multirracial sustentada apenas por sua condição de ser branca. ${ }^{7}$

"Where there are structural injustices, these usually produce not only victims of injustice, but persons who acquire relative privileges by virtue of the structures. Most who occupy positions of power with respect to the structures also have privileges that coincide with this power. In most situations of structure injustice, however, there are relatively privileged persons who have relatively little power as individuals or in their institutional positions." (2004, p.35).

Aquilo que Macintosh denomina privilégio branco permite, nas sociedades multirraciais, que os membros do grupo privilegiado ignorem suas especificidades raciais - branquidade - uma vez que estas são parte da "normalidade". O Branco passa a ser, no imaginário da sociedade, um padrão universal, neutro e destituído de identidade racial. O "Ser branco" implicaria ser normal, objetivo, verdadeiro, possuir mérito, motivação, além de reverter num acúmulo de apoios, considerados invisíveis porque nunca questionados, que contribuem para o capital já acumulado. Este privilégio permite aos brancos escaparem à vigilância intelectual e social. (WILSON, 2005, p.88).

Essa percepção branca de mundo, que foi designada por Macintosh de monoculturalismo racial, pressupõe que todos pertencem a um mesmo sistema cultural, sistema este que tem os contornos reconhecidos por aqueles que detêm maior poder étnico-racial ${ }^{8}$, essa percepção expurga das práticas cotidianas brancas de comportamento o potencial político que elas possuem nas interações sociais cotidianas.

\footnotetext{
${ }^{7}$ You may be familiar with Peggy McIntosh's famous list of 46 ways a white person benefits from white privilege, usually without even being aware of it. For example, not having to educate one's children to be aware of racism for their own protection; not being asked to speak as a representative for all the people of their racial group; not thinking that one has been singled out because of one's race if pulled over for a traffic stop. (Delgado \& Stefancic p.09, 2005)

${ }^{8}$ Apud WILSON, 2005, p. 88.
} 
Os brancos são racializados em sociedades racializadas simplesmente por viverem nessa sociedade, a possibilidade de verem-se como neutros, padrão de normalidade, em si já é uma racialização de percepção de mundo. Em oposição à negritude que demanda uma valoração positiva em face da sua construção negativa a branquidade trás como elemento de sua construção a neutralidade, construída para manter a superioridade em face dos outros grupos raciais.

"Chamo branquidade o capital racial que possuem todas as pessoas no Brasil que são classificadas no censo do IBGE como brancas e que na maioria das vezes não assumem essa categoria. Não a assumem, mas usufruem os privilégios dela derivados. E branquidade é a condição de privilégio racial própria das sociedades latino-americanas da mestiçagem. Difere da condição de branco em países como os Estados Unidos, África do Sul e Zimbabwe porque nessas sociedades foi construída uma condição explícita de branco, socialmente aceita de modo inequívoco, o que não é o caso em países como o Brasil, em que a ideologia da mestiçagem tem permitido uma manobra de diluição na esfera pública dessa condição de branco. A branquidade é o privilégio da brancura em uma sociedade racista sem a responsabilidade que ela gera em termos de desigualdade racial." (CARVALHO, 2007, apud SANTOS 2007, p.233).

A percepção da branquidade é hoje identificada como premissa necessária para estabelecer-se um debate, de forma eficaz, entre todos os membros da sociedade sobre as desigualdades raciais, uma vez que a não-consciência dessa situação implica em uma constante miopia sobre a natureza e a dinâmica das relações raciais no país, por parte dos brancos que permanecem ausentes dos debates e das propostas de construção do país e de sua história inclusiva democrática e multicultural.

Desvelar esse privilégio implica demandar, de todos os brancos, comprometidos ou não com a militância pela igualdade, o reconhecimento de que estes integram o grupo classificado como o grupo opressor, que ainda se vale dos privilégios construídos em bases escravistas. Desvelar tal privilégio significa, 
também, entender os pactos narcísicos ${ }^{9}$ entre os brancos e a sua luta silenciosa pela manutenção dos privilégios raciais no cotidiano.

\section{5 - Racismo}

Alguns afirmam que o preconceito é tão antigo quanto a humanidade e que o racismo, no entanto, não tem mais de 500 anos. Outros entendem que apesar de o termo ter sido cunhado recentemente, o fenômeno é muito antigo e remonta aos primeiros séculos da história da humanidade, entendendo como racismo aquilo que alguns definem como etnocentrismo, somente.

Quando procuramos definir o termo racismo, a primeira dificuldade encontrada é a pluralidade de significados que o termo encerra, em especial na tradição política e acadêmica brasileira. A divergência presente nos meios político e acadêmico quanto à definição do termo, torna-se bem menos acentuada no que diz respeito à percepção da existência material do racismo enquanto prática social.

Ideologizado da forma como o conhecemos por volta de 1920, o racismo moderno enquanto conceito e realidade já foi objeto de diversas leituras e interpretações. Já recebeu várias definições que nem sempre dizem a mesma coisa, nem sempre têm um denominador comum. Quando utilizamos esse conceito em nosso cotidiano, não lhe atribuímos mesmos conteúdo e significado, daí a falta do consenso até na busca de soluções contra o racismo. (MUNANGA, 2004, p.21).

Nesta perspectiva, o surgimento do racismo era considerado fruto do conceito de raça, tendo origem no latim ratio. O professor Carlos Moore, ao

\footnotetext{
${ }^{9}$ (BENTO, 2002), traz é sua tese o conceito de pacto narcísico. Esse conceito é firmado, pela autora, a partir da construção americana de "White Cumplicity", que conclui que esse pacto, entre os brancos, implica na negação e evitação dos problemas resultantes das relações raciais desiguais no Brasil. Esse comportamento teria como objetivo a manutenção de privilégios raciais. O medo da perda de tais privilégios e da responsabilização pelas desigualdades raciais constituem o substrato psicológico que gera a projeção do branco sobre o negro, carregada de negatividade.
} 
apresentar o primeiro conceito de raça, traz como elemento de dúvida em sua obra a relação de causa e efeito entre a noção de raça e o fenômeno do racismo, entre a identificação do racismo como uma produção européia e a comum identificação de sua gênese vinculada à escravização dos africanos, à expansão do capitalismo e à chamada modernidade.

O professor enfatiza que:

"Não se trata aqui de desvalorizar a importância do surgimento da categoria raça enquanto um condicionante relativo das possíveis interpretações contemporâneas do racismo, mas de observar que o projeto científico moderno de uma compreensão sistemática e racializada da diversidade humana, operada nos séculos XVIII e XIX, apenas foi possível em função do critério fenotípico em escala planetária. As críticas reportadas às teorias evolucionistas como a teoria de Spencer, o determinismo racial de Lombroso e o darwinismo social, que apostaram em uma continuidade entre dados físicos e morais, afetam a possibilidade de uma discussão do racismo calcada na história dos conflitos entre povos decorrentes das diferenças fenotípicas." (MOORE, 2007, p.10).

Partindo desta concepção, o professor consegue identificar que desde o seu início, que não se restringe ao século XIX e às teorias científicas, mas localiza-se na antiguidade, o racismo sempre foi uma realidade social e cultural pautada exclusivamente no fenótipo, antes de ser um fenônemo político e econômico pautado na biologia. O fenótipo é um elemento objetivo, real, que não se presta à negação ou confusão; é ele, não os genes, que configura os fantasmas que nutrem o imaginário social. É o fenótipo que serve de linha de demarcação entre os grupos raciais, e como ponto de referência em torno do qual se organizam as discriminações "raciais".(Moore, 2007,p.11), assim o professor defende que focar a análise deste fenômeno a partir do século XVI para cá, concentrando-se majoritariamente no período seguinte à Segunda Guerra Mundial; ignora o fato de que a maior parte da humanidade (Índia, América Latina, Oriente Médio, China...) vive, hoje, sob a pressão dos modelos tipológicos de relações raciais surgidos antes da modernidade. (MOORE, 2007,p.18).

Pensamos, entretanto, que a dinâmica racismo e capitalismo, que podemos observar nos dias atuais, faz do tipo de racismo que se busca combater 
um fenômeno que deita raízes na antiguidade, mas que foi teorizado, da forma como o conhecemos hoje em dia, para fundamentar uma ordem econômica surgida no século XIX. Nesse período o escravismo enquanto modelo econômico do Estado Português, e de suas Colônias, precisou de justificativas para seguir adiante. Apesar dessa estreita ligação do racismo moderno com o capitalismo não há como se confundir a discriminação de classes com a discriminação de raças, uma vez que uma precede historicamente a outra: "Marx, no fim de sua vida, em 1882, escrevia a Engels dizendo-Ihe: "Mas, nossa luta de classes, tu sabes muito bem onde a encontramos: nós a encontramos nos historiadores franceses quando eles narravam a luta das raças". (FOUCAULT, 2005, P.93).

Assim entende Foucault que:

"o discurso racista foi apenas um episódio, uma fase, a variação, a retomada em todo caso, no final do século XIX, do discurso da guerra das raças, uma retomada desse velho discurso, já secular naquele momento, em termos sóciobiológicos, com finalidades essencialmente de conservadorismo social e, pelo menos em termos sócio biológicos, com finalidades essencialmente de conservadorismo social e, pelo menos em certo número de casos, de dominação colonial." (2005, p. 75)

O racismo um vocábulo amplamente utilizado por pessoas desejosas de combater as doutrinas da desigualdade, tornou-se desgastado, chegando quase a adquirir uma conotação pejorativa. O racismo tem duas fontes: uma instintiva e outra histórica. A origem daquilo que chamamos racismo encontra-se no comportamento instintivo de preservação do território e sua defesa. É um comportamento primário, original. Porém, não foi esta a fonte que fomentou o racismo elaborado da forma como o conhecemos hoje. Este fenômeno data da modernidade ocidental, é histórico. O racismo elaborado não é instintivo, e sim fruto da sociedade em que vivemos, fruto da nossa história.

O professor Carlos Moore aponta as dinâmicas do processo de surgimento do racismo comum a todas as circunstâncias em que ele surgiu. São elas: 
"a) a fenotipização de diferenças civilizatórias e culturais; b) a simbologização da ordem fenotipizada através da transferência do conflito concreto para a esfera fantasmático (isso implica fenômenos como a demonização das características fenotípicas do vencido em detrimento da exaltação das características do segmento populacional vencedor); c) a ereção de uma hierarquização raciológica da ordem social, mediante a subordinação política e socioeconômica permanente do mundo populacional conquistado. Iremos esquematizar essas três dinâmicas que se encontram na gênese do fenômeno do racismo da seguinte maneira: o O processamento simbológico pelo qual uma coletividade, convertida em grupo dominante, secreta uma consciência grupal para a rejeição de uma alteridade especificamente fenotípica, com a finalidade de exercitar uma dominação grupal permanente sobre essa última; A organização da sociedade numa ordem sistêmica, segundo um critério especificamente fenotípico, para exercer uma gestão monopolística dos recursos globais, de modo a excluir o grupo dominado e subalternizado; o A elaboração de estruturas intelectuais normativas (ideologias), especificamente destinadas a: I) regulamentar as relações entre dominados e dominantes; II) inculcar um sentimento permanente de derrota no segmento subalternizado; III) criar uma convicção narcísica de inquestionável superioridade permanente e invulnerabilidade no setor dominante." (2007, p.182).

Guardada as devidas proporções, o racismo consiste, então, em um fenômeno histórico, cujo substrato preconiza por uma doutrina, científica ou não, que defende a hierarquização dos grupos humanos. Ela forma um gradiente das diferenças culturais e fenotipias, que são utilizadas para atribuir desníveis morais, psicológicos, fisicos e intelectuais aos indivíduos. O racismo segundo o professor Moore em suas raízes na idéia de desigualdades inatas entre os indivíduos que remonta antes do século $\mathrm{V}$ a. C. ${ }^{10}$.

\footnotetext{
${ }^{10}$ Aristóteles, discípulo de Platão, analisou a questão da igualdade chegando à conclusão de que existem duas classes de justiça: a universal e a particular. No primeiro sentido, justa é a conduta havida em conformidade com a lei, já no segundo sentido, é compreendida a justiça como ato deliberado, que realiza a igualdade não sem privilegiar a lei, mas também como possibilidade de retificá-la através da igualdade. Ao conceber a justiça distributiva como critério formal de tratamento igualitário a todos, fez com que este igual permanece-se abstrato, podendo assim justificar qualquer sistema, como decorrência da sua vagueza. O juiz, para Aristóteles, seria, então, eqüidistante das partes e estabelecedor da igualdade: “... as coisas se passam como se houvesse uma linha dividida em dois segmentos desiguais, e o juiz subtraísse a parte que faz com que o segmento maior exceda a metade e a acrescentasse ao segmento menor.". (MUSSE, 1998, P.16) Contudo Aristóteles concebia uma igualdade proporcional, conforme as aptidões de cada um. Essas aptidões obedeceriam à natureza humana uma vez que para Aristóteles os homens não eram todos iguais pois uns nasciam para servir e outros para serem servidos.
} 
$\mathrm{Na}$ época das grandes viagens, quando a percepção da diferença entre os homens tornou-se tema constante de debate e reflexão, a teoria Darwinista ${ }^{11}$ foi transplantada para o reino humano na tentativa de explicar as diferenças entre os povos "descobertos" dando, assim, legitimidade científica às crenças que justificavam a dominação de europeus sobre os povos colonizados. (SILVA JR, 2000. p.19)

Esta correlação estreita entre patrimônio genético, aptidões intelectuais e inclinações morais tornou-se a postura ideológica mais influente a partir do século XIX. Muitos foram os teóricos que defenderam a teoria da desigualdade inata entre os humanos e, dessas ideologias, derivaram leis, políticas e práticas sociais negativas, das políticas estatais, por exemplo, dos EUA, da África do Sul, da Alemanha e do Brasil. Esses países ao optarem por excluir e segregar determinados grupos raciais, terminaram por aplicar políticas de extermínio ou de tolerância ao extermínio desses grupos. A realidade das relações raciais no Brasil foi construída a partir de uma forte influência desse modelo de racismo adotado pelas políticas imperialistas e idealizado no século XIX.

A Convenção da ONU de 1965 para Eliminação de Todas as Formas de Discriminação Racial ${ }^{12}$ traz, em seu primeiro artigo, a definição de discriminação racial:

\begin{abstract}
"Qualquer distinção, exclusão, restrição ou preferência baseada em raça, cor, descendência ou origem nacional ou étnica que tem por objetivo ou efeito anular ou restringir o reconhecimento, gozo ou exercício num mesmo plano, (em igualdade de condição), de direitos humanos e liberdades fundamentais no domínio político econômico, social, cultural ou em qualquer outro domínio de sua vida". (ONU, 1965)
\end{abstract}

\footnotetext{
${ }^{11}$ Charles Darwin foi o propositor da teoria da Seleção Natural, um mecanismo essencial da evolução, aceito pela generalidade da comunidade científica como a melhor explicação da especiação tal como evidenciada nos registros fósseis, e a base da Teoria da Evolução, geralmente usada como referência para a evolução biológica e mudanças nas características da vida. Freqüentemente, é uma referência à teoria da evolução moderna baseada nas idéias de Charles Darwin da seleção natural em seu livro "A Origem das Espécies".

${ }^{12}$ Convenção de 21 de Dezembro de 1965, inserida no ordenamento brasileiro pelo Decreto Legislativo $n^{\circ} 23$, de 1967, e promulgada pelo Decreto $n^{\circ}$ 65.810. de 1969.
} 
A definição de racismo adotada pela ONU deixa claro que a manifestação deste, nos dias atuais, não exige do agente domínio científico ou retórico das teorias raciais, bastando que tal prática reflita o conteúdo nuclear da ideologia: atos e atitudes, exclusões e as preferências baseados em critérios raciais que gerem restrições ao acesso a bens sociais necessários para o gozo de direitos e, conseqüentemente, a persecução de um projeto de vida digna.

O propósito da Unesco quando da elaboração desta declaração foi explicitar e demonstrar que não buscava impedir o rancor entre os diferentes grupos, mas apenas impedir condutas que, fundadas em fatores raciais, têm por fim, ou efeito, a violação de direitos.

As atitudes racistas deixam de derivar de doutrinas e passam a formar um sistema difuso de pré-disposições, crenças, expectativas de ação que não estão formalizadas ou expressas logicamente. (GUIMARÃES, 1999, p.17). É assim que o racismo também pode ser identificado e definido como um conjunto de atitudes, preferências e gostos instruídos pela idéia de superioridade entre raças. Desse modo as pessoas que consideram os negros menos inteligentes, feios, menos trabalhadores, ou fisicamente mais fortes são comumente referidas como racistas por cercearem os direitos dessas pessoas. (Guimarães, 1999, p.17).

"Racism attaches significance to bodily characteristics skin color, hair type, facial features, and constructs hierarchies of standard or ideal body types against which others appear inferior, stigmatized, deviant, or abject. In Western structures of antiBlack racism this hierarchy appears both as dichotomous and scaler. That is, racial categorization is organized around a Black/White dichotomy, and this dichotomy organizes a grading of types according to how "close" they are to Black (most inferior) or White (the superior)". (YOUNG,2005, p.14).

O Professor Pierre André Taguieff afirma que as teorias anti-racistas não estão funcionando porque elas utilizaram argumentos da sabedoria. Estes argumentos são levados em consideração unicamente no mundo em que eles são considerados sérios. Cada um vive, no entanto, em vários mundos: um científico, outro da experiência vivida, etc. No mundo da razão, cada um pode estar de 
acordo com o anti-racismo científico. Mas no mundo da experiência vivida, existe sempre aquele "mas".... autor conclui que a crise anti-racista se deve a estes dois fatores: quando o discurso é científico, ele passa ao largo do problema; quando é simbólico, faz parte do mesmo campo de idéias. ${ }^{13}$

No Brasil, quando tomamos como ponto de definição não a mera rotulação, mas a relação de poder, o racismo não se consubstancia, de forma alguma, um estrangeirismo. Conforme Hasenbalg (1995, p.244), as pessoas não se iludem com relação ao racismo no Brasil: sejam elas brancas, negras ou mestiças. Elas sabem que existe preconceito e discriminação racial, o que o mito da democracia racial faz é dar sustentação a uma etiqueta de regra implícita de convívio social.

Assim também se identifica como racismo o sistema de desigualdade de oportunidades, inscrito na estrutura de uma sociedade, que pode ser verificado apenas estatisticamente. Tal sistema, ainda que não exista independente dos seus agentes, não pode ser confundido, seja com a doutrina, seja com o sistema de atitudes, seja com os comportamentos individuais concretos. O próprio sistema de desigualdades raciais se encarregaria de reproduzir as inferioridades sociais de fato, bastando que determinada pessoa nascesse e se socializasse em uma família típica de sua situação racial. (GUIMARÃES, 1999, p.19).

A professora Young, em seu artigo sobre injustiças estruturais, assim define o racismo:

"As I understand it, racism consists in structural processes that normalize body aesthetic, determine that physical, dirty or servile work is most appropriate for members of certain groups, produces and reproduces segregation of members of these racialized groups, and renders deviant the comportments and habits of these segregated persons in relation to dominant norms of respectability."(2005, p.15)

\footnotetext{
${ }^{13}$ Essa colocação do Pesquisador deixa bem inserido o racismo na definição do conceito de opressão de Marylin Frye, que trazia como "One of the most characteristic and ubiquitous features of the world as experienced by oppressed people is the double bind - situations in which options are reduced to a very few and all of them expose one to penalty" $(1983$, p.02)
} 
Nesse sentido, a população reconhece as desigualdades raciais, mas não admite reconhecer a existência de raças socialmente construídas. Dessa forma, as pessoas identificam a existência de um racismo sem aceitar a possibilidade de racialismo. Importante distinguir estas duas expressões, uma vez que o racialismo constitui-se na simples percepção e aceitação de que existem raças, mesmo que sejam socialmente construídas, para identificação dos grupos na humanidade e na sociedade. A partir do reconhecimento dos racialismos (percepção das raças humanas) presentes na sociedade brasileira e base das práticas racistas, poderse-ia aplicar políticas de intervenção de cunho afirmativo sem espaço para os argumentos no sentido de que raças não existem e da impossibilidade de identificação de quem é negro no Brasil.

A aceitação desse racialismo reconheceria que raça não é apenas um conceito, mas também uma realidade simbólica. É um termo da linguagem popular que se identifica com imagens reconhecíveis, como a cor da pele ou o aspecto dos cabelos. O racismo seria a conjunção do racialismo com a variante poder, percepção essa de Matteuci (2004, p1.059) bastante elucidativa. Ele a atribui ao uso político de resultados aparentemente científicos para levar à crença de superioridade entre as raças e justificar atitudes de perseguição e discriminação contra as consideradas raças inferiores. Em nome de um fortalecimento social, cria-se uma identidade contra um inimigo comum, uma ideologia ou sistema de representações que legitima e justifica a desigualdade ${ }^{14}$.

Taguief (apud D'Asky,2001, p27-28) em seu modelo quadripartido de racismo situa as possíveis manifestações dessa ideologia em dois âmbitos, "heterófobo", que nega a identidade anulando a diferença entre os grupos e sua identidade, e o "heterófilo", que nega a humanidade tornando absoluta a diferença de um grupo em relação ao outro. Após constatar este modelo, o autor o entrecruzou com dois pares de critérios opostos, "universalismo" e "diferencialismo" alcançando um modelo com os seguintes tipos de racismo:

\footnotetext{
${ }^{14}$ Apud VIEIRA JUNIOR, 2005, p. 26.
} 
a) Racismo universalista espiritualista - clama a missão civilizatória das raças superiores. Os grupos são mais ou menos evoluídos, assimiláveis, esclarecidos, tem como anti-racialismo a busca da desconstrução dos particularismos locais considerados bárbaros e acredita no progresso para todos por meio de uma educação que racionalize os costumes.

b) Racismo universalista do tipo biomaterialista - defende a existência de raças adiantadas e atrasadas. Legitimando o extermínio ou a dominação, tem como anti-racismo a unidade da humanidade, que encara como um fato. Apresenta como meta a mistura entre raças com o fim de assimilação universal.

c) Racismo Diferencialista Espiritualista - encara a diferença de forma absoluta, vendo todas as possíveis misturas como um processo destruidor da humanidade. Tem como anti- racismo a preservação das diferenças, estimulando a reivindicação do direito à diferença.

d) Racismo Diferencialista do tipo biomaterialista - o último do modelo quadripartido postula que as raças humanas são quase espécies, vendo os cruzamentos interraciais como transgressões às leis da natureza. Têm como antiracismo o respeito às diferenças culturais, pensadas como indissociáveis das diferenças biológicas.

Considerado um dos homens mais habilitados, atualmente, na França, a falar sobre esse fenômeno que é o racismo, o filósofo e cientista político PierreAndré Taguieff, em entrevista recente, ponderou que existe hoje um novo tipo de racismo dentro de seu modelo não mais quatripartido, que ele chama de racismo cultural ou diferencialista. Cultural, porque não se fala em termos de Biologia ou Genética, e sim de etnias e culturas. Diferencialista, porque não hierarquiza essas culturas $^{15}$.

O professor Antonio Sergio Alfredo Guimarães traz a distinção de Apih, identificando dois tipos de racismo em razão da sua manifestação: o interior e o exterior ao grupo racial. O racismo do tipo extrínseco traça distinções morais entre os membros de diferentes raças por acreditar que a essência racial traz consigo

${ }^{15}$ Pierre-Andre Taguieff é filósofo, cientista político e historiador integra o Centro Nacional de Pesquisas Científicas da França. Revista Superinteressante, Março de 1993. 
algum conteúdo moralmente relevante. Os membros de diferentes raças se distinguem em aspectos que justificam um tratamento diferenciado, por exemplo, honestidade, coragem, inteligência. Já os racistas intrínsecos acreditam que cada raça tem um status moral diferente, pensando que o fato de uma pessoa pertencer a uma raça igual a sua justifica o tratamento preferencial em face desta pessoa. (GUIMARÃES, 1999, passim).

O Estado brasileiro, a exemplo de outros, por muito tempo desenvolveu políticas pautadas na crença de que o racismo resumia-se a condutas individuais ou a modelos de condutas legitimadas por políticas de Estado, a exemplo do apartheid na África do Sul, das castas na Índia, das leis segregacionistas nos EUA e do Estado nazista na Alemanha, entre outros.

Da Mata nota que o ponto crítico de nosso sistema é a sua profunda desigualdade; quando se estabelecem distinções para baixo, isto é entre escravos e senhores desiguais perante a lei, essas dessemelhanças revelam-se, também, para cima; todo o universo social acaba por colocar tudo em gradações. O autor justifica, então, que neste sistema de relações raciais e sociais que formulamos e que ainda reverbera nos dias atuais não existe a necessidade de segregação, porque as hierarquias assegurariam a superioridade branca. A intimidade, a consideração, o favor e a confiança tornam-se valores associados á hierarquia indiscutível que emoldura a sociedade e não é um caráter nacional português como afirmava Freyre. .(1981, P.75).

Hoje, o modelo de racismo, para o qual têm se voltado as políticas dos Estados comprometidos com a sua eliminação no século XXI, não busca identificar os fins através dos quais essa ideologia busca alcançar, mas sim dar visibilidade aos mecanismos dos quais o racismo se vale para alcançar os resultados de desigualdades na fruição de bens mínimos, identificados em pesquisas e necessários para uma vida digna.

O conceito de racismo institucional, ou racismo sistêmico, foi criado em 1967 por Carmichael e Hamilton (King, 1996 apud Werneck, 2004) 
O Programa Nacional de Combate ao Racismo institucional ${ }^{16}$ adotou para si a mesma definição utilizada pelo Conselho Britânico.

"O fracasso das Instituições e organizações em promover um serviço profissional e adequado às pessoas devido à sua cor, cultura, origem racial ou étnica. Ele se manifesta em normas, práticas e comportamentos discriminatórios adotados no cotidiano do trabalho, os quais são resultantes da ignorância, da falta de atenção, do preconceito ou de estereótipos racistas. Em qualquer caso, o racismo institucional sempre coloca pessoas de grupos raciais ou étnicos discriminados em situação de desvantagem no acesso a benefícios gerados pelo Estado e por demais instituições e organizações" ((CRE/UK, 1999, p. 2 apud WERNECK, 2004))

Os reformadores do setor privado na Austrália o definiram como

"(...) um processo indireto e em grande medida invisível que pode ser comparado ao nepotismo ou a uma barreira de ascensão social. É um termo que abrange as barreiras e procedimentos de seleção/promoção, muitas vezes não-intencionais, que servem para colocar em desvantagem os membros de grupos étnicos minoritários. O racismo institucional impede que as instituições esquivem-se com desculpas tecnocráticas da responsabilidade pelo racismo, afirmando que as técnicas estão ligadas à raça apenas por coincidência, bem como impede o bloqueio da tomada de consciência do papel que estas instituições representam na manutenção, perpetuação e intensificação do racismo." (MUSUMECI, 2005, p.235)

O resultado dos esforços de reconceitualizar o significado de racismo nas sociedades contemporâneas - que criminalizam essas práticas - e o fenômeno do tokenismo $^{17}$ não impedem a manutenção das desigualdades de acesso a direitos

\footnotetext{
${ }^{16}$ Instituição é uma estrutura social organizada que toma decisões pelas quais ninguém tem responsabilidade individualmente. e elas não mudam sozinhas, elas instituições e estruturas só mudam quando um grupo de pessoas, em posição de poder decidir e efetuar a mudança, decidem que querem mudá-la. (SCHRUPP, 2008, p.8)

${ }^{17}$ Tokenismo seria o fenômeno de formação de Tokiens, que são pessoas desproporcionalmente representadas, numericamente, em determinados espaços que antes lhes eram negados. São representantes de minorias as quais são inseridas/incluídas com a finalidade de provar a não discriminação nestes locais. Assim, são identificados "bons" e "maus" Tokiens, seriam aqueles
} 
fundamentais destes grupos permanece. Em razão deste contexto, surge o conceito de racismo estrutural.

O uso desse conceito por teóricos americanos busca, na verdade, dar visibilidade ao esforço de explicar as razões pelas quais as desigualdades raciais permanecem, mesmo com a aplicação de políticas de ações afirmativas e com o surgimento de representantes Afrodescendentes em inúmeros espaços de poder, e entender porque a raça continua a ser um forte condicionador dos índices de bem-estar. A idéia de racismo estrutural baseia-se na premissa de que uma análise estrutural deve fazer parte de qualquer trabalho com a finalidade de igualdade para que este seja bem sucedido.

A abordagem institucional foca nos procedimentos e práticas dentro das instituições enquanto uma abordagem estrutural busca centrar sua atenção nos arranjos e interações inter institucionais.

Essa concepção surgiu de experiências históricas demonstrando que, a não ser que a temática de raça e racismo seja levantada e pontuada sempre de forma intencional e consciente em todos os espaços produtores de políticas públicas com a finalidade de inclusão, essa temática, da desigualdade racial, tende a ser ignorada mesmo entre os ativistas sociais mais progressistas; a cegueira racial torna-se o único consenso, implicando em manutenção das desigualdades constatadas.

Todas as sociedades possuem arranjos institucionais que ajudam a distribuir e arranjar os benefícios sociais. Essas estruturas não são neutras, e entender o funcionamento delas, e os mecanismos que levam a resultados injustos socialmente falando é muito difícil levando-se em conta apenas uma instituição.

representantes de minorias que compactuam com a lógica de funcionamento do espaço, seriam meras simulações de inclusão sem relevância real, mau tokien, ou aquele que não compactua e tem um postura combativa frente a estrutura posta no local, indicando simbolicamente uma igualdade de representação por vir no espaço onde foi inserido - bom tokien. (Fineman, Martha Albertson., 1998). 
"When we judge that structural injustice exists, we are saying precisely that at least some of the normal and accepted background conditions of action are not morally acceptable. Most of us contribute to a greater or lesser degree to the production and reproduction of structural injustice precisely because we follow the accepted and expected rules and conventions of the communities and institutions in which we act. Usually we enact these conventions and practices in a habitual way, without explicit reflection and deliberation on what we are doing, having in the foreground of our consciousness and intention immediate goals we want to achieve and the particular people we need to interact with to achieve them." (2004, p.21).

Essa é a premissa de compreensão estrutural do racismo ${ }^{18}$, que critica a percepção individual e institucional do racismo não as afirmando como irrelevantes para entender a desigualdade racial, mas pontuando a sua insuficiência para explicá-lo em sua complexidade. Esse não é um debate semântico, mas a apresentação de diferentes percepções de produção da desigualdade racial moderna; cada um identifica diferentes causas e pontua diferentes respostas para essa desigualdade.

A proposta pode parecer muito ampla, uma vez que :

"Although structures are difficult to see at the level of individual interaction, social actors nevertheless have a practical consciousness of the rules and resources entailed by them that open or limit options for themselves and others." (YOUNG, 2004,P.13)

\footnotetext{
${ }^{18}$ Iris M. Young em seu artigo "Taking the Basic Structure Seriously" usa a metáfora de Marilyn Frye's no seu artigo "Opression" para ilustrar o funcionamento das estruturas de opressão de gênero e a importância da compreensão destas em uma perspectiva estrutural e não somente institucional. Merilyn Frye em sua metáfora diz: "Consider a birdcage. If you look very closely at just one wire in the cage, you cannot see the other wires. If your conception of what is before you is determined by this myopic focus, you could look at that one wire, up and down the length of it, and be unable to see why a bird would not just fly around the wire any time it wanted to go somewhere. Furthermore, even if, one day at a time, you myopically inspected each wire, you still could not see why a bird would gave trouble going past the wires to get anywhere. There is no physical property of any one wire, nothing that the closest scrutiny could discover, that will reveal how a bird could be inhibited or harmed by it except in the most accidental way. It is only when you step back, stop looking at the wires one by one, microscopically, and take a macroscopic view of the whole cage, that you can see why the bird does not go anywhere; and then you will see it in a moment. It will require no great subtlety of mental powers. It is perfectly obvious that the bird is surrounded by a network of systematically related barriers, no one of which would be the least hindrance to its flight, but which, by their relations to each other, are as confining as the solid walls of a dungeon." (FRYE,Marilyn, 1983, p.4-5)
} 
Contudo, acreditamos que é da ausência desta proposta complexa percepção das injustiças sociais, incluindo racismo, que enfatiza o poderoso impacto das dinâmicas inter-institucionais, desigualdade de recursos e legados históricos nas desigualdades raciais constatadas pelos dados atuais, que terminamos por apresentar políticas incompletas e insuficientes. Essa proposta de compreensão do racismo como um fenômeno estrutural passível de intervenções institucionais busca trazer a percepção de que as desigualdades são resultantes do efeito cumulativo de diversos obstáculos comunicantes, resultantes de uma ideologia formadora de sociedades multiculturais que têm o racismo como ideologia de base fundante das suas instituições.

Finalizamos com a assertiva de Brandão (2002, p.90) de que "em virtude da heterogeneidade racial brasileira as manifestações racistas modernas se apresentam de tal modo complexas que já não se sabe como nem onde discernilas sob os seus múltiplos disfarces". Esta seria a explicação para as conclusões contraditórias a que chegam os pesquisadores, alguns afirmando e outros negando a persistência do preconceito, discriminação, racismo e privilégios brancos nas instituições nacionais. 


\section{Capitulo 2}

\section{0 - Dignidade da pessoa humana e racismo no Estado Democrático brasileiro.}

É necessário apresentar a evolução e definição do conceito de dignidade da pessoa humana em toda a sua possível amplitude. Somente entendendo bem o conceito de dignidade humana e os limites necessariamente delineados para sua proteção é que se torna possível identificar quais âmbitos desse direito são atingidos pelo racismo em suas diversas manifestações sejam elas individuais, institucionais ou estruturais.

Buscaremos, também, demonstrar como o racismo negação da dignidade dos indivíduos de diferentes raças implica nos dados Estatais e não Estatais que denunciam a desigual fruição de bens socialmente necessários para a vida digna entre brancos e negros.

Buscar-se-á, em um segundo, momento analisar a faceta da dignidade da pessoa humana na sua exteriorização como respeito à igualdade entre raças. Mais especificamente, tentaremos identificar as formas como o racismo brasileiro, com suas características históricas peculiares, atinge esse direito/qualidade, intrínseco do ser humano, cotidianamente. 


\section{1 - A dignidade e suas inúmeras facetas:}

\subsubsection{Significado da palavra Dignidade.}

A palavra dignidade apresenta-se definida, nos dicionários da língua portuguesa da seguinte forma :

\footnotetext{
"substantivo feminino

1 qualidade moral que infunde respeito; consciência do próprio valor; honra, autoridade, nobreza Ex.: sempre se mostrara homem de muita d.

2 qualidade do que é grande, nobre, elevado

3 modo de alguém proceder ou de se apresentar que inspira respeito; solenidade, gravidade, brio, distinção x.: <agir com d.> $<$ repeliu o insulto com d.>

4 respeito aos próprios sentimentos, valores; amor-próprio Ex.: sua d. impediu-o de continuar naquele casamento degradante 5 prerrogativa, honraria, título, função ou cargo de alta graduação Ex.: foi elevado à $\mathrm{d}$. de ministro

6 Rubrica: termo eclesiástico. Estatística: pouco usado. benefício vinculado a cargo proeminente ou a alto título em um cabido

7 Derivação: por metonímia. Rubrica: termo eclesiástico. Estatística: pouco usado. indivíduo detentor desse benefício"
}

Em resumo, seria a dignidade uma qualidade moral que infunde respeito, honra e nobreza; é a qualidade do que é grande, elevado, prerrogativa de um cargo de alta graduação, merecimento e nobreza.

Historicamente, essa expressão sempre esteve vinculada a esses valores sociais e políticos, de existência do indivíduo em uma comunidade e às atividades exercidas por ele em sua vida social, bem como às elevadas funções e aos altos cargos ou títulos.

As primeiras vezes em que surge em textos jurídicos a palavra, dignidade, traz o caráter de cargo ou honraria como, por exemplo, do art $7^{\circ}$ da Declaração dos Direitos do Homem e do Cidadão de 1789 na qual se faz constar que os cidadãos são admissíveis a "todas as dignidades, cargos, e emprego público". 
Em sua tese, Albrecht analisa que o conceito de dignidade naquele período girou em torno de três significados os quais segundo a autora foram: "(i) o que é adequado a, que deve respeito a uma pessoa ou coisa; (ii) a excelência dentro de uma sociedade organizada, o poder ou a autoridade; e, em virtude de tudo isso, (iii) a estima ou o apreço". (2006, p.98).

Nessa acepção de lugar ocupado na sociedade, a dignidade é compreendida como um direito concedido, que demanda o dever de respeito em face dos outros, mas que por ser um direito delegado, resultado de lugar ocupado ou de função exercida, também pode ser revogado.

\subsubsection{A dignidade da pessoa humana.}

A ampliação de significado que a palavra dignidade apresenta atualmente surge quando este termo passou a ser associado ao adjetivo humanidade. A exemplo da forma como ela apresenta-se na Declaração Universal de Direitos Humanos de 10 de Dezembro de 1948:

"Art. 1': da 'Todos os seres humanos nascem livres e iguais em dignidade e direitos. Dotados de razão e consciência, devem agir uns para com os outros em espírito e fraternidade'.

Art $4^{\circ}$ 'Todo o Homem tem o Direito de em todo o lugar ser reconhecido como pessoa"'

Temos a partir dessa declaração a ampliação do significado desse termo que passa a fundamentar a concepção de Direitos Humanos ou de Direitos indisponíveis e inerentes a todos os membros da família humana. Esse novo sentido dado a essa palavra traz a concepção de que todos os membros da humanidade possuem um valor inerente e intrínseco que merece respeito e proteção, incondicionais.

Construindo tipologias filosóficas sobre a dignidade humana, Maurer (2005, p.68), em seu ensaio identifica três grupos: 
No primeiro grupo estariam os filósofos Cícero, Pascal, Kant, Levinas, Mounier, que compreendem a dignidade como um absoluto inalienável fazendo do ser humano pessoa humana e não podendo ser questionada ou relativizada.

O segundo grupo traz como representante mais significativo o filósofo Hegel que, segundo a autora, entende a dignidade como um fundamento imanente uma qualidade que está por vir, ao desenvolver-se e fortalecer-se. Para Hegel, o homem também encontra a sua dignidade ao desenvolver-se a serviço do Estado.

Maurer ainda apresenta, dentro desta concepção de dignidade, defensores de uma ontologia progressiva. Para eles, o direito fundamental é o direito de qualidade de vida. Num sentido similar, é possível apontar a definição de Luhmann, para quem a pessoa alcança a sua dignidade a partir de uma conduta auto determinada e da construção exitosa de sua própria identidade.(SARLET, 2005, p.29). A concepção de Luhmann de dignidade dinâmica, fragiliza a dignidade como prestação e afigura-se questionável pelo prisma jurídicoconstitucional, como aponta Harble (2005, p.122).

O terceiro grupo, por fim, reúne os filósofos que negam a idéia de dignidade da pessoa. Dentre eles, Levi-Strauss insiste na necessidade de suprimir a idéia de superioridade do homem em relação ao animal, para esse filósofo essa pretensa superioridade é um mito. A dignidade para ele seria um fato mental pressuposto uma vez que o espírito não existe.

Em razão dessa amplitude de tipologias é que a dignidade da pessoa humana, na concepção ampla de direito incondicional do homem, apresenta-se como um conceito multidimensional com inúmeras facetas. Ela surge associada a um grande conjunto de condições necessárias à existência humana e, por essa razão, torna-se um princípio/valor complexamente composto que abarca vários aspectos como a própria vida, passando pela integridade física, psíquica, integridade moral, liberdade, condições materiais de bem-estar, etc. (VILHENA, 2006, p.63).

A complexidade de aspectos que compõem a dignidade humana hoje apresentada faz com que ela contenha na sua definição justificativas de cunho religioso, filosófico e científico e tenha necessariamente vinculado à sua 
realização a concretização do pleno exercício de todos os direitos fundamentais. Os Direitos Fundamentais foram declarados pelo Estado com a finalidade de proteger a dignidade, permitindo, assim, que consensualmente a coloquemos como diretriz central da Idéia de Direitos Humanos e conseqüentemente dos Direitos Fundamentais.

Mesmo entre os autores que divergem sobre o significado das nomenclaturas, Direitos Fundamentais e Direitos Humanos ${ }^{19}$, a dignidade humana apresenta-se como valor constituinte das ordens jurídicas constitucionais que protegem e declaram direitos do homem.

Por acreditar que existem direitos inerentes a essa qualidade intrínseca, integrante e irrenunciável de cada ser humano - a qual precisa ser reconhecida, respeitada, promovida e protegida e por essa mesma razão não pode ser criada, concedida ou retirada (embora possa ser violada) pelo Estado ou outros indivíduos (SARLET, 2006, p.42, a; 2005, p.19), é que abraçamos uma concepção de que existem direitos necessários para a vida digna os quais ainda não foram positivados.

Ainda nesse sentido vale pontuar a afirmação da Ministra Carmem Rocha para quem a degradação encontra sempre novas formas de se manifestar e por essa razão exige do Direito novas formas de assegurar a justiça, protegendo o indivíduo do aviltamento do Homem ou da desumanização da convivência. (1999, p.26).

\footnotetext{
${ }^{19}$ A diferença na definição dos conceitos de Direitos Humanos e Direitos Fundamentais pode ter como exemplo da definição feita pelo professor Ingo Wolfgang onde ele afirma que apesar de serem ambos os termos ("direitos humanos" e "direitos fundamentais") comumente utilizados como sinônimos, a explicação corriqueira, e diga-se de passagem, procedente para a distinção é de que o termo "direitos fundamentais" se aplica para aqueles direitos do ser humano reconhecidos e positivados na esfera do direitos constitucional positivo de determinado Estado, ao passo que a expressão "direitos humanos" guardaria relação com os documentos de direito internacional, por referir-se àquelas posições jurídicas que se reconhecem ao ser humano como tal, independentemente de sua vinculação com determinada ordem constitucional, e que, portanto, aspiram à validade universal, para todos os povos e tempos, de tal sorte que revelam um inequívoco caráter supranacional (internacional).) esta definição do professor Sarlet diverge da nomenclatura do professor Carlos Santiago Nino $(1989$, p.15) justificada pelo autor pela não aceitação de Direitos Humanos primordialmente como direitos jurídicos uma vez que a possibilidade de que existam sistemas que não reconheçam esses direitos e da necessidade de proteção destes direitos, exatamente pelo seu não reconhecimento é que fazem necessário uma construção da idéia de direitos garantidores da dignidade humana numa compreensão que vá para além do entendimento de Direitos Humanos como, apenas, direitos positivados.
} 
A partir desta crença de que existem e podem surgir direitos necessários para a proteção da dignidade humana, os quais ainda não foram declarados, a exemplo do direito de reconhecimento, é que defendemos a concepção de que o conceito de Direitos Fundamentais e de Direitos Humanos é similar e estes vocábulos distinguem-se, apenas, pela condição de direitos declarados e positivados pelo Estado ou não.

Essa concepção permite compreender que os possíveis aviltamentos à dignidade humana, bem como as necessidades de proteção desta, evoluem como a história da humanidade, trazendo sempre novas demandas. Ela permite também compreender o leque de Direitos necessários para a garantia de uma existência digna como um Horizonte, inalcançável, mas nem por isso não ambicionável, pois a busca por este constitui-se num processo de permanente construção e desenvolvimento. ${ }^{20}$

Essa complexidade de constituição acarreta uma constatada dificuldade na busca de uma definição objetivamente jurídica do conceito de dignidade da pessoa humana, afinal, diferente dos outros direitos fundamentais, não é um aspecto específico da existência humana, mas uma qualidade do ser humano, e por isso, passa a ser um valor mais do que uma norma.

Apesar da dificuldade de definição do que seria, juridicamente, dignidade humana conceito de natureza porosa, ambígua e em permanente construção, mesmo em seu conteúdo, (ROCHA, 1999, p.25) essa dificuldade não pode servir como justificativa para a não busca por uma definição, pois, a identificação mínima do que é este direito/valor inerente, universal e indisponível é o que garantirá uma certa segurança jurídica quando da provocação jurisdicional para proteção desse Direito.

Além do mais, diferente da percepção filosófica do conceito de dignidade humana, a jurisdição constitucional quando provocada a manifestar-se sobre o que é, e o que protege esse direito inerente ao se humano não pode recusar a manifestar-se, negando a identificação ou definição desta em suas diversas dimensões.

\footnotetext{
${ }^{20} \mathrm{~A}$ imagem dos Direitos Humanos como um horizonte inalcançável, cuja busca torna àqueles que o procuram pessoas melhores leva à conclusão de uma das parábolas de Confúcio em que este afirma que "o verdadeiro caminho não é o fim, é o caminhar".
} 
Como bem alerta o professor Ingo W Sarlet, essa segurança Jurídica, definição do que é juridicamente a dignidade apesar das dificuldades, deve ser buscada, uma vez que tendo uma definição aberta, mas minimamente objetiva, os limites tênues do que seria a dignidade, evita-se que esta, sirva como justificativa do seu contrário $(2006$, p.58, a).

Apenas essa definição mínima permitirá que um conceito muito amplo, que não pode ser apontado com precisão, tenha os seus contornos delineados para que, apesar da mesma dignidade que justifica o direito à vida ou á morte, no caso da Eutanásia, (MAUER, 2005,p.62), não termine por legitimar aquilo que ela não é.

Partindo da premissa de que é inviável delimitar os contornos desse conceito jurídico sem pontuar a construção histórica desta idéia, de um direito fundamental e inafastável do ser humano, destacamos como marco inicial desta construção evolutiva da idéia de dignidade humana a antiguidade clássica ocidental. Nesse momento, como dissemos anteriormente, temos a dignidade apenas como grau de reconhecimento do indivíduo pela sua comunidade, ou seja, um sentido apenas sócio político e não moral, como apresentamos inicialmente no primeiro parágrafo.

\subsection{3 - Origens Históricas.}

A Religião e a Filosofia são as instituições apontadas como as responsáveis pelas primeiras idéias bases que influenciaram os valores e o pensamento construtor de uma concepção de Dignidade Humana desvinculada dos parâmetros sócio-políticos anteriores.

No ocidente, Cícero é identificado como quem desenvolveu uma concepção de valor intrínseco à pessoa, desvinculado de cargo ou posição social; Cícero trouxe a essa concepção já existente, de dignidade, um sentido moral (SARLET, 2006, p.31, a). Os sofistas, assim como os estóicos, encontravam na Natureza, a lei natural da ordem que governava o mundo, a justificativa para a existência de leis aplicáveis a todos os seres humanos sem distinção. (COMPARATO, 2004, p.14). 
A filosofia Estóica desenvolveu-se durante seis séculos, até o século III da era cristã, tendo os seus princípios em vigor durante toda a Idade Média e mesmo além dela, pois, apesar de esta filosofia não ser um pensamento sistemático, ela organizou-se em torno de idéia centrais, como a unidade moral do ser humano e a dignidade do homem, noções que permanecem caras a nós no mundo moderno.

O estoicismo trouxe as bases da filosofia cristã, concepção de mundo esta que por muitos autores traz uma estreita ligação com o valor dignidade da pessoa humana. (Mario SILVA NETO, 2005, p.23, COMPARATO, 2004, p.17, SARLET, 2006, p.30.).

O Cristianismo concretizou um modelo ético de pessoa e trouxe, a partir das pregações do apóstolo Paulo, um universalismo evangélico, ao afirmar que os seres humanos, como filhos de Deus eram merecedores de respeito por compartilharem de uma natureza comum.

Ao entender a pessoa como a substância do homem, o cristianismo construiu uma concepção de que todos os seres humanos têm os mesmos direitos, por possuírem uma unidade substancial na humanidade. Esta unidade é composta de algo distinto de sua aparência corporal ou das atividades que cada um exerce na sociedade tornando, assim o cristianismo, todos iguais perante o criador.

Essa concepção, de que todos os seres humanos têm os mesmo direitos, tem sua fundamentação amparada na afirmação cristã de que o homem é o ponto máximo do projeto da criação de Deus, que o fez à sua imagem e semelhança.

Segundo a Doutrina jusnaturalista, existem direitos inalienáveis do homem que limitam o exercício do poder dos governantes e encontravam-se acima da ordem positivada, ou reconhecida. Isso fazia parte dos ensinamentos do São Tomas de Aquino, que se destacou sustentando, com essas argumentação, a concepção de fundamentação cristã e estóica, durante a idade média da dignidade humana.

A relação da dignidade da pessoa humana com a religião ocorre desde os primórdios. No entanto é importante destacar aqui a crítica que o professor SARLET (p.30, 2006 ) faz à idéia de que a doutrina cristã seria o berço da 
dignidade. Ele aponta como não ideal "reivindicar - no contexto das diversas religiões professadas pelo ser humano ao longo dos tempos - para a religião cristã a exclusividade e originalidade quanto à elaboração de uma concepção de dignidade da pessoa"21. Vincular a concepção de dignidade somente a uma tradição judaico cristã pode justificar a crítica de que a dignidade não é um conceito e postulado intercultural, o que poderia tornar-se um fator impeditivo até mesmo da sua universalização e globalização em um contexto mundial multicultural. (OTFRIED HOFFE apud SARLET, 2006, p.39, a).

Assim, todas as culturas possuem concepções de dignidade humana, apesar do fato de que nem todas elas concebem esse valor como vinculado à idéia de Direitos Humanos.

\subsubsection{A Dignidade Secularizada.}

Com o surgimento da concepção filosófica secularizada de Immanuel Kant, os fundamentos, jusnaturalistas e religiosos da idéia de ser humano - com direitos inerentes à sua condição - deixam de ter tanta relevância. O filósofo apresenta a dignidade humana como a faculdade de determinar a si mesmo e em conformidade com a representação de certas leis (KANT, 2005, p.33).

Immanuel Kant construiu um conceito de dignidade humana tão amplo e desvinculado dos valores religiosos que justifica o motivo pelo qual, ainda hoje surge como teórico identificado com as bases de uma conceituação filosófica fundamental deste termo.

Foi o filósofo Immanuel Kant quem desvinculou essa qualidade do homem de construir livre e independentemente a sua própria existência e seu próprio destino na autodeterminação inerente à natureza humana, das justificativas religiosas.

\footnotetext{
${ }^{21}$ João Batista Herkenhoff identifica origens pré cristãs, ou concomitantes ao cristianismo mas de culturas que não tinham contato com essas filosofia religiosa da idéia de dignidade humana, o autor enumera os Astecas, o confucionismo na China e os valores do Ubuntu comuns em inúmeras etnias da África negra. passim, HERKENHOFF. Curso de direitos humanos: gênese dos direitos humanos, v.1, 1994
} 
A idéia Jusnaturalista e religiosa de dignidade torna-se laicizada e racional com a construção de Kant cuja concepção de dignidade parte da autonomia ética do ser humano. O autor afirma que esta autonomia é o fundamento da dignidade e que esta é um atributo apenas encontrado nos seres racionais, o homem. Sendo somente este capaz de viver em condições de autonomia, isto é, guiandose pelas leis que edita, constitui esta autonomia o fundamento da dignidade e da natureza humana.

"A dignidade não consiste apenas no fato de ser o humano, diferentemente das coisas, considerado e tratado, como um fim em si e nunca como um meio para a consecução de determinado resultado. Ela resulta também do fato de que, pela sua vontade racional, só a pessoa vive em condições de autonomia, isto é, como ser capaz de guiar-se pelas leis que ele próprio edita".(COMPARATO, 2003,p.21)

Kant trazia como justificativa desta peculiaridade da pessoa, que a tornava humana e conseqüentemente com dignidade, a capacidade de sermos legisladores universais, isto é, de termos a faculdade de agir e se determinar conforme a representação de certas leis. Essa faculdade, segundo Kant, só pode ser encontrada em seres racionais e aquilo que serve como princípio objetivo de auto-determinação à vontade é o fim. Este se é dado só pela razão, tem que valer para todos os seres humanos (KANT, 2005, p.228):

"Um ser espiritual, que é, ao mesmo tempo, fonte e imputação de todos os valores. Consciência e vivência de si próprio, todo ser humano se reproduz no outro como seu correspondente e reflexo de sus espiritualidade, razão por que desconsiderar uma pessoa significa em última análise desconsiderar a si próprio. Por isso é que a pessoa é um centro de imputação jurídica, porque o Direito existe em função dela e para propiciar seu desenvolvimento. Nisso já se manifesta a idéia de dignidade de um ser racional que não obedece a outra lei senão àquela que ele mesmo, ao mesmo tempo, institui". (SILVA,1998, p.89-94).

A autonomia, princípio fundado no fato de ser o homem racional e conseqüentemente livre, na construção kantiana quase se confunde à idéia de 
dignidade e de liberdade. No entanto, tais direitos - dignidade, liberdade bem como a idéia de autonomia - são elementos distintos, apesar de inseparáveis. ${ }^{22}$

A defesa incontestável e intransigente da liberdade implicaria na possibilidade de que se justificasse a omissão em face de absurdos como que se encarasse normal uma pessoa que vive em situação abaixo do mínimo existencial em condições degradantes, apenas para propiciar a sua liberdade. Essa concepção ampla de dignidade não se resume à liberdade e demanda também como necessária à solidariedade.

Uma concepção distinta da construção kantiana, de dignidade como valor intrínseco e comum a todos os seres humanos, que se apresenta como relevante é a construção de Hegel para quem a dignidade, negando a concepção ontológica, é algo necessariamente conquistado e por essa mesma razão passível de ser perdida, tornando-se digna a pessoa somente a partir do momento em que assume a sua condição de cidadão (SARLET,a, 2006, p.36).

A dignidade precisa não somente dos atos verdadeiramente humanos por meio dos quais se realiza, mas também, de condições externas que lhe permitirão essa atuação: circunstâncias afetivas, sociais, econômicas, estatais, etc (MAUER,2005,p.82). Marx no mesmo sentido, entendendo-a como algo a ser conquistado e desenvolvido, a define como uma conquista histórica do homem. ${ }^{23}$

Os professores Ingo Sarlet e Herrera Flores, inseridos no debate, concebem a dignidade com um sentido cultural, além do ontológico, indentificando-a como resultado do trabalho de diversas gerações da humanidade em seu todo. É por isso que a dignidade possui dimensões culturais e naturais que interagem interminavelmente (SARLET, 2005, p.27). Nesse mesmo sentido, a entendem os defensores do evolucionismo, como Durkheim.

$\mathrm{Na}$ sua filosofia, Hegel tratou a dignidade em três planos os quais são: dignidade no reconhecimento como pessoas iguais, isto é centro de competências

\footnotetext{
${ }^{22}$ Hegel, Kant e Descartes são indicados como filósofos que reduziram o ser à razão, mas a razão manifesta apenas uma dimensão prática da autonomia, uma dos elementos constituintes da dignidade.

${ }^{23}$ “(...) pode-se concluir pelo entendimento deque há um humanismo na construção teórica de Marx, porquanto está expresso em suas aspirações à libertação do homem alienado e à total realização do ser humano. Certamente que o humanismo em Marx resulta da luta pela 'libertação do homem das alienações econômicas, sociais, políticas, filosóficas e religiosas. Uma vez libertado de todas essas servidões, o homem conseguirá sua expansão e realização e poderá comunicar-se com os outros de forma autêntica"'. (Wolkmer, 2004, p.08)
} 
iguais para a titularidade de direito, reconhecimento recíproco, como sujeitos dotados de necessidades distintas, e, finalmente, no reconhecimento recíproco que perdoa, mutuamente, de um infinito valor do outro que é idêntico para aquele que reconhece uma auto -retratação e ordenação num contexto relacional geral substancial, num contexto de interação. (SEELMAN, 2005, p.58)

Mauer, valendo-se da construção hegeliana de distintas noções do processo de consciência "para si" e "em si", aponta que o conhecimento absoluto só é alcançado quando as duas noções coincidem com duas concepções de dignidade:

A primeira, a dignidade "para si", é pessoal e condicionada pela educação, pelo ambiente em que se existe e pela auto imagem. É passível de "evolução" o que levaria ao final a uma coincidência entre a noção de dignidade "para si" e a noção de dignidade "em si". A dignidade "para si" não pode ser absolutizada uma vez que o conceito de dignidade não comporta concessões em função de apreciações subjetivas. (Mauer, p.72), o exemplo apresentado por Mauer de que o fato de que o filho de um escravo, que cresceu vendo o pai apanhando abusivamente, encara esta realidade como natural, e não contrário a sua dignidade esse comportamento ainda assim, afeta a dignidade dessa pessoa.

O julgamento do assim identificado "caso do lançamento do anão" ${ }^{24}$ é um exemplo concreto de jurisprudência nesse sentido.

Hegel refere-se a consciência "para nós", que representaria os diferentes atores sociais; a dignidade,nesse contexto, seria um consenso social que assim como a dignidade "para si", é passível de evolução.

A dignidade "em si", por final, é a fonte e finalidade da pessoa humana (Mauer, 2005, p.74), sendo assim multifacetada e de difícil delimitação. Em razão

\footnotetext{
${ }^{24}$ Numa cidade francesa chamada Morsang-sur-Orge, a Prefeitura, utilizando seu poder de polícia, resolveu interditar bares onde se praticasse o lançamento de anões. O Sr. Wackenheim um dos anões que trabalhava no bar, questionou a interdição. Valendo-se do argumento de que necessitava daquele trabalho para a sua sobrevivência recorreu ao Comitê de Direitos Humanos da ONU que em setembro de 2002 manteve a decisão do Conselho de Estado francês, reconhecendo que o lançamento de anão violaria a dignidade da pessoa humana e, portanto, deveria ser proibido, mesmo em face de autorização e vontade do anão o Sr. Wackenheim .

Fonte: http://noticias.uol.com.br/inter/reuters/2002/09/27/ult27u26540.jhtm. Acesso em 18/01/2009.
} 
disso que surge o dever ético de protegê-la evitando a sua degradação e promovê-la afim de que evolua até tal ponto.

A dignidade, segundo Hegel, pode-se apresentar passível de compreensão em um duplo aspecto: a dignidade ontológica e a dignidade axiológica. A primeira seria um status assegurado a todo ser humano em razão da sua natureza. A segunda exige, para sua plena realização, uma série de deveres, requisitos de um viver ético, muitos dos quais como corolários dos direitos pertinentes à dignidade ontológica.(ALBRECHT, 2006, p.173).

Apesar da relevante contribuição de Hegel, a maioria das ordens jurídicas do mundo baseia-se na noção kantiana de dignidade humana. Ela é entendida como algo que não pode ser perdido, uma vez que a compreensão de que determinadas pessoas alcançam um ponto de ausência de humanidade que os desvincula desse direito inerente e ontológico fundamentou a concepção nazista de que judeus, homossexuais, deficientes, entre outros grupos não eram mais humanos, não podendo ser tratados como tal.

\subsubsection{A dignidade em toda sua amplitude Comtemporânea.}

Todo ser humano, mesmo não identificado como uma pessoa completa, possui uma dignidade indiscutível. Nesse sentido, cabe identificar duas dignidades, a das ações das pessoas, e a humana. Uma pessoa que experimenta condições degradantes e age de forma contrária a esse valo/princípio, não perde a dignidade, não se torna indigna apesar de cometer algo indigno. (MAURER, 2005, passim). É por ser pressuposto da idéia de justiça humana que dita a condição de superior do homem como ser de razão e sentimento é que independe de merecimento pessoal ou social, ela é inerente à vida e, por isso um direito pré-estatal. (Rocha, 1999, p.27).

O art 1 da Declaração Universal da ONU (1948) revitalizou as premissas basilares da doutrina kantiana, concedendo a esse conceito com sede na filosofia uma juridicidade como forma de reação após às barbáries da primeira metade do século XX. Consagrou, -se, assim, como outros ordenamentos jurídicos, a idéia 
de que o homem, apenas em razão da sua condição humana e independente de qualquer outra razão, é titular de direitos e deveres que devem ser impostos, protegidos e reconhecidos por seus semelhantes e pelo Estado. (SARLET, 2006 P.38, a).

Essa característica, a dignidade, construída exitosamente, resultaria em uma conduta auto-determinada e numa construção exitosa de identidade - autorepresentação, afinal ela guarda íntima relação com as complexas, incalculáveis e imprevisíveis manifestações da personalidade humana. Ela traz, segundo o professor Ingo, uma necessária dimensão comunitária, uma vez que esta conduta termina por vincular-se à condição humana de todo indivíduo e ao fato de que estas pessoas, todas dotadas de igual dignidade, existem socialmente em determinada comunidade ou grupo. (SARLET, 2006, P.52, a).

A dignidade é, assim, limite e tarefa dos poderes estatais, não podendo ser perdida ou alienada. Reclama-se do estado que este guie suas ações tanto a preservação como a promoção da dignidade, especialmente, criando condições que possibilitem o pleno exercício e a fruição desta.

Nessa compreensão de dignidade, ela é algo a ser promovido, e não apenas protegido, apresenta-se como um valor também dependente da ordem comunitária. Assim, questiona-se até que ponto é possível ao indivíduo realizar, ele próprio, parcial ou totalmente, suas necessidades existenciais básicas, bem como sua busca pela felicidade sem, para tanto, o concurso do Estado e da comunidade (PODLECH apud SARLET, 2006, p. 47, a,).

A dignidade é afirmada historicamente, não progredindo mas formalizando o seu reconheciemnto por meio do respeito. Segundo Kant, esse respeito tem duplo aspecto: relaciona-se tanto à dignidade do indivíduo quanto à do outro. (MAURER, 2005, P.89).

\subsection{6 - A Dimensão Intersubjetiva da dignidade.}

Assim surge o destacado dever de respeito para com a dignidade no âmbito da comunidade dos seres humanos, Kant pontua a necessidade de não subtração intencional do esforço do outro na sua persecução pela felicidade e a 
necessidade de uma concordância positiva na busca desta felicidade pelos seus semelhantes, construindo também uma compreensão intersubjetiva de dignidade:

“(...) é verdade que a humanidade poderia subsistir se ninguém contribuísse para a felicidade dos outros, contanto que também lhes não subtraísse nada intencionalmente; mas se cada qual se não esforçasse por contribuir na medida de suas forças para os fins dos seus semelhantes, isso seria apenas uma concordância negativa e não positiva com a humanidade como fim em si mesma. Pois que se um sujeito é um fim em si mesmo, os seus fins têm de ser quanto possível os meus, para aquela idéia poder exercer em mim toda a sua eficácia." (2005, p.71)."

Partir de uma situação básica de compreensão do ser humano em relação aos demais -sem com isso, é claro, justificar sacrifícios individuais em prol da comunidade - requer que todos autores confluam na compreensão de que a dignidade, nessa perspectiva intersubjetiva, implica também "numa obrigação geral de respeito pela pessoa (pelo seu valor intrínseco como pessoa), traduzida num feixe de deveres e direitos correlativos de natureza não meramente instrumental, mas sim, relativos a um conjunto de bens indispensáveis ao 'florescimento humano'”. (GONÇALVES LOUREIRO apud INGO, 2006 P.54).

A dignidade, assim como a existência humana, sem prejuízo de sua dimensão ontológica, só faz sentido no âmbito intersubjetivo; essa natureza aponta para a dimensão política da dignidade.

A razão para essas construções de dignidade enquanto algo intersubjetivo é o fato de que ela se apresenta como uma capacidade humana de agir conforme aquilo que se julga correto em relação às demais pessoas, e não simplesmente em conformidade com aquilo que maximize o bem - estar imediato do indivíduo (VILHENA, 2005, p.65).

"Se o fim natural de todos os homens é a realização de sua própria felicidade, não basta agir de modo a não prejudicar ninguém. Isto seria uma máxima meramente negativa. Tratar a humanidade como um fim em si implica o dever de favorecer, tanto quanto possível, o fim de outrem. Pois, sendo o sujeito um fim em si mesmo, é preciso que os fins de outrem sejam por mim 
considerados também como meus".(KANT apud COMPARATO, 2003, p.23).

A partir de Kant, dignidade e autonomia são conceitos vinculados e não passíveis de serem desligados um do outro: "Autonomia é, pois, o fundamento da dignidade da natureza humana e de toda a natureza racional" (KANT, 2005, p.79).

Carlos Nino entende essa relação entre os princípios de autonomia e de dignidade da pessoa não está muito clara, uma vez que o princípio de autonomia implica no de dignidade. Esse professor argumenta que o que torna relevantes as escolhas de uma pessoa é a possibilidade de materialização do seu plano de vida. Mas a dignidade, prevalece sobre o princípio da autonomia quando esta autonomia busca justificar restrições e sofrimentos, aparentemente, auto impostos. (NINO, 1989, p.291).

Além da autonomia, a dignidade da pessoa humana engloba necessariamente respeito e proteção da integridade física e emocional (psíquica) da pessoa, como foi anteriormente dito. Isso significa, por exemplo, a proibição da pena de morte, da tortura e da aplicação de penas corporais, bem como a utilização da pessoa para experiências científicas (SARLET, 2006, p. 89).

2.1.7 Uma aproximação de um conceito normativo de Dignidade.

Ingo Wolfgang Sarlet propõe uma definição de dignidade humana em que busca abarcar todos os âmbitos de compreensão desta enquanto valor, a fim de permitir identificá-la enquanto direito que demanda proteção. Destarte, o professor diz que a dignidade humana é:

"A qualidade intrínseca e distintiva reconhecida em cada ser humano que o faz merecedor do mesmo respeito e consideração por parte do estado e da comunidade, implicando, neste sentido, um complexo de direitos e deveres fundamentais que assegurem a pessoa tanto contra todo e qualquer ato de cunho degradante e desumano, como venham a lhe garantir as condições existenciais mínimas para uma vida saudável, além de propiciar e promover sua participação ativa e co-responsável nos destinos da própria 
existência e da vida em comunhão com os demais seres humanos."(SARLET, 2006, p.60, a).

Essa evolução de pensamento sobre o que é ser humano, o que é ser pessoa e quais os valores ligados a essas formas de ser, apresentada é que justifica a proteção por parte do Estado e do direito reconhecido de dignidade.

Diferente de outras normas fundamentais como a integridade física, intimidade, vida, propriedade, a dignidade da pessoa humana é apresentada como um valor próprio que identifica o ser humano como tal e dele não pode ser destacada (SARLET,a, 2006, p.40/41). Dessa forma, a dignidade deixou de ser um elemento da filosofia moral para tornar-se um princípio jurídico, que exige condutas por parte do Estado e suas instituições negativas e positivas no sentido de promovê-lo e protegê-lo.

É por essa razão que a dignidade traz dois âmbitos de interpretação. Se for tomada como valor absoluto, privilegia o indivíduo em sua perpétua contraposição com a sociedade. Se for encarada como princípio, a dignidade da pessoa humana necessariamente relativiza-se, partindo de uma concepção de princípio, em que nenhum princípio pode ser absoluto em relação aos outros. Nesse caso e de que a dimensão intersubjetiva da dignidade pode, em uma existência coletiva, ser mais valorizada do que a sua dimensão individual.

Mas, ainda que se reconheça a possibilidade de alguma relativização e mesmo de eventuais restrições da dignidade enquanto princípio, não há como transigir no que diz respeito à preservação de um elemento nuclear intangível da dignidade, que, na fórmula de Kant, consiste na vedação de qualquer conduta que importe em coisificação e instrumentalização do ser humano (KANT, 2005, p. 138). ${ }^{25}$

Somente excepcionalmente, podem ser feitas limitações ao exercício dos direitos fundamentais, "mas sempre sem menosprezar a necessária estima que merecem todas as pessoas enquanto seres humanos" (MORAES, 2001, p.48).

\footnotetext{
${ }^{25}$ Nesse sentido, a construção do professor Durig para quem a dignidade seria atingida sempre que uma pessoa fosse rebaixada a objeto, mero instrumento, tratada como coisa, descaracterizada como sujeito de direitos. (Apud Ingo, 2006, P. 58)
} 
É por essa razão que a proteção da dignidade ou dos direitos naturais do homem, em face do Estado e a história da limitação de poderes do Estado frente a esse direito inalienável do ser humano é ponto central, também, na história da construção dos Direitos Humanos.

2.1.8- A proteção da dignidade como dever e fundamento do Estado.

Juridicamente, a dignidade apresenta-se como um direito público subjetivo e fundamental do indivíduo em face do Estado, e da sociedade, e ao mesmo tempo um encargo constitucional endereçado ao Estado.(HARBLE, 2005, p.137).

A dignidade humana é mencionada em inúmeros textos legais a exemplo da carta das nações unidas, da Declaração Universal dos Direitos Humanos, do estatuto da UNESCO, do art $1^{\circ}$ da Constituição Alemã, do art $1^{\circ}$ da Constituição Portuguesa, do art 27 da Constituição Italiana, do preâmbulo da Constituição Espanhola e do preâmbulo da nossa Constituição Federal, além de outras leis fundamentais de jovens Estados constitucionais. Isso representa, a presença da dignidade humana em tantos textos legais constitucionais, uma reação aos horrores testemunhados durante a Segunda Guerra, dentre eles o holocausto ${ }^{26}$, que trouxe a consciência de que toda a forma de desumanização atinge não somente a pessoa, mas a humanidade como um todo. (ROCHA,1999, p.24).

A Constituição Alemã, identificada como modelo para o mundo, positivou esse princípio de base filosófica ao declarar em seu primeiro artigo e primeiro inciso que a dignidade humana é inviolável e que é dever de todas as autoridades estatais respeitá-la e protegê-la. (SILVA, 1998, p.89).

\footnotetext{
${ }^{26}$ A Ministra Carmem Lucia especula que, talvez, sem o evento do nazismo o princípio da dignidade humana talvez não se tornasse princípio matriz do Direito, mas em face do holocausto surgiu uma demanda jurídica de proteção da pessoa em face das possíveis degradações a que poderia sujeitá-la o Estado. (Rocha, 1999, p.30).
} 
Em razão dessas construções históricas é que o reconhecimento e a proteção da dignidade é premissa sine qua non das ordens constitucionais quando estas pretendem constitui-se como um Estado Social Democrático Material de Direito (SARLET, 2006, p.44). Tal modelo de Estado Social Democrático Material de Direito tem por finalidade, legitimadora da ordem, proteger a dignidade humana, reconhecendo-a como qualidade integrante, inalienável e irrenunciável da condição de ser humano e cidadão, devendo o Estado reconhecê-la, respeitá-la, promovê-la e protegê-la.

Enquanto direito fundamental, isto é, Direitos Humanos declarados pelo Estado, a dignidade humana consiste não apenas na garantia, negativa dos direitos de liberdade, civis e políticos, direitos que garante que a pessoa não será alvo de ofensas ou humilhações. A dignidade também traz a necessária afirmação, dos direitos sociais econômicos e culturais, que garante e promove o direito ao pleno desenvolvimento da personalidade de cada indivíduo.

Assim de conceito filosófico de fonte em concepção moral, a dignidade apresenta-se como uma forma do Direito considerar o homem e o que se pode fazer, numa sociedade política, com ele, por ele e dele. (ROCHA, 1999, p.29).

No qualificativo fundamental, dos direitos humanos positivados, acha-se a indicação do que se tratam esses direito. Eles são direitos que regulamentam situações jurídicas sem as quais a pessoa humana não se realiza, não convive e, às vezes, nem mesmo sobrevive, por isso todos os direitos que garantem a realização, convivência e vida humana, são protetores da dignidade e por isso fundamentais.

Os Direitos fundamentais enumeram as várias nuances de apresentação da dignidade do ser humano e dos valores necessariamente protegidos para a sua manutenção, podemos assim afirmar que todos os direitos positivados como direitos fundamentais, bem como os direitos defendidos como direitos humanos, têm como fim declarado proteger a dignidade enquanto valor, e o princípio da dignidade é declarado enquanto compromisso do Estado que afirma ter como missão proteger esse valor da pessoa humana. 


\subsection{9 - A Dignidade no Ordenamento Brasileiro.}

No Brasil, a Constituição de 1988 traz a dignidade da pessoa humana como princípio Fundamental da República concretizando o vago conteúdo axiológico em causa, transformando-o em regras deontológicas de conduta (FALCÃO, 2006, p. 95). A localização deste direito enquanto princípio no artigo primeiro o inclui no roll de Direitos protegidos como Cláusulas Pétreas da Carta Magna.

Ikawa aponta que a dignidade enquanto princípio pauta-se em uma idéia de ser humano caracterizado pela autonomia moral contextualizada, pela possibilidade de ação intersubjetiva, pela razão instrumental e, principalmente, pela não instrumental, pela identidade (e autenticidade), pela linguagem, pela aversão à dor e pela busca da felicidade. (IKAWA,2006, P.64).

Diante do compromisso assumido pelo Constituinte no artigo $1^{\circ}$, inciso III da Carta Magna, assume tal princípio como fundamento da própria organização política do Estado Democrático de Direito. Assim, os órgãos jurisdicionais possuem a obrigação de assegurar a proteção da dignidade humana em face das possíveis violações dos direitos e deveres decorrentes dela, proteção esta que constitui meta permanente do Estado, do Direito e da Humanidade.( SARLET, 2006, P.27, a). O Estado existe para assegurar ao homem condições que permitam a ele atingir os seus fins; o homem é o fim da organização Estatal.

Nos termos do art. $1^{\circ}$, inciso III, da Constituição da Republica a dignidade da pessoa humana é um dos princípios estruturantes do Estado Democrático de Direito e, portanto, do Estado Brasileiro:

"Por princípio estruturante entende-se uma idéia constitutiva e indicativa de diretrizes básicas de todo 0 ordenamento jurídico. A dignidade da pessoa humana atua como fundamento do princípio estruturante do Estado Democrático de Direito e, em conseqüência, impregna a totalidade da ordem jurídica, espraia-se por todos os ramos do direito positivo e inspira não só a atividade legislativa como também a atuação do poder judiciário." (ROMITA,2005, p. 251) 
Como princípio, a noção de dignidade humana apresenta a idéia da ilegitimidade de instituições ou medidas que discriminem entre os homens, condicionando, por exemplo, os efeitos das distribuições de recursos ou da cominação de penas, à fatores que não estão sujeitos a livre vontades desses indivíduos. (NINO, 1989, p.288).

A dignidade humana, assim, apresenta-se como a base do Estado Constitucional que ao declarar esse princípio expressa suas premissas antropológico-culturais. (HARBLE, 2005,p.150). O Estado Constitucional tem como fonte da legitimidade do seu poder o respeito e a proteção à dignidade humana $^{27}$ a qual necessita para isso do engajamento material e ideal do Estado afim de garantir o mínimo existencial material a todos os seus cidadãos. ${ }^{28}$ Proteger a dignidade, então, constitui-se num dever jurídico-fundamental do Estado Constitucional. ${ }^{29}$

Em razão da dinamicidade da dignidade, no processo histórico de desenvolvimento estatal constitucional, as novas formulações sobre direitos fundamentais atuam como novas atualizações dos postulados base de proteção da dignidade em face de novas zonas de perigo, por meio de um constante aperfeiçoamento jusfundamental. ${ }^{30}$

Os Direitos Garantidores da dignidade são a justificativa da estrutura que modela o Estado Constitucional Democrático de Direito, único regime até agora conhecido e compatível com esse valor/garantia uma vez que a sociedade democrática tem uma moral, que consiste em estabelecer como princípio a dignidade igual e universal das pessoas. (LOPES, 2005. p.67).

\subsubsection{0- A Dignidade como fundamento do Estado Democrático.}

Esse modelo de Estado é, então, uma construção que reflete a vontade dos membros de uma sociedade de proteção desses direitos inerentes ao homem

\footnotetext{
${ }^{27}$ Ibdem, p.140.

${ }^{28}$ Op.cit, p.138.

${ }^{29}$ Op. cit, p.132

30 Op. Cit, p.129
} 
uma vez que este se constitui de titulares de direitos fundamentais e destes é que decorrer em última instância o poder Estatal.

Para Maria Celina Boldrin de Moraes, a dignidade é o substrato do qual decorrem quatro princípios jurídicos fundamentais: a igualdade, que veda qualquer discriminação arbitrária e fundada nas qualidades das pessoas; a liberdade, que assegura a autonomia ética e, portanto, a capacidade para liberdade pessoal; a integridade física e moral, que asseguram um mínimo de prestações matérias que garantam uma vida com dignidade, isso é o mínimo existencial e por fim, a solidariedade, que garante a promoção e da coexistência humana em suas diversas manifestações. Esses princípios segundo a autora encontram-se vinculados a um conjunto de direitos fundamentais. (MORAES, apud SARLET, 2005, p.34).

A estruturação político - institucional dos Estados Democráticos de Direito busca positivar em seu ordenamento os direitos necessários à vida humana digna, ou seja, os direitos fundamentais ${ }^{31}$. É por essa razão que este deve propiciar condições para que a dignidade não seja violada por terceiros. Esse dever pode ser cumprido jurídico-defensivamente bem como jurídico prestacionalmente, por caminhos jurídicos materiais, processuais e por meios ideais e materiais. (HARBLE, 2005, p.136).

Adalbert Podlech desenvolveu cinco condições centrais para a garantia da dignidade humana: a liberdade do medo existencial no Estado social por meio da possibilidade de trabalho e um seguro social mínimo; a igualdade normativa dos homens, que apenas permite desigualdades fáticas justificáveis; a defesa da identidade e da integridade humana por meio da garantia do livre desenvolvimento espiritual do individuo; a limitação do poder estatal por meio do seu enquadramento pelo Estado de Direito; e, finalmente, o respeito da corporalidade do homem como momento de sua individualidade autônoma e responsável. (PODLECH apud HARBLE, 2005, p.122-123).

\footnotetext{
${ }^{31}$ Três são as funções essenciais do Estado, propiciar educação ao povo em igualdade de condições (Escola e Universidade), proteger-lhe a saúde (sistema médico hospitalar) e complementar a segurança e a paz pública com bom sistema penitenciário, que possa atingir a sua finalidade de recuperação do delinqüente. (Gusmão, 2000, P.359)
} 
Estes direitos têm como pressuposto para sua realização o Estado de Direito: "há um estreito nexo de interdependência genético e funcional, entre o Estado de Direito e os direitos fundamentais, já que o Estado de Direito exige e supõe para sê-lo garantir os direitos fundamentais, enquanto que estes exigem e supõem para a sua realização o Estado de Direito" (PEREZ LUNI apud ALBRECHT, 2006, p.129).

É em razão dessa constatada vinculação entre os dois institutos que a Evolução histórica destes, direitos fundamentais e Estado Democrático de Direito, confundem-se sendo o segundo o modelo de Estado que expressa a ambição de uma sociedade pela proteção do primeiro.

Fazendo destas garantias fundamentais norma suprema e ao inseri-las no texto constitucional, o Estado elege a proteção da pessoa como fundamento de sua legitimidade. As atividades Estatais devem estar estruturalmente dirigidas à promoção da dignidade. O dano a esses bens é um ataque ao próprio Estado Democrático de Direito, pois reduz sua projeção na realização do bem comum.

No entanto, não se pode esquecer que o Estado é uma criação humana e que apesar de sempre nos referirmos ao Estado de modo substantivo, não podemos esquecer que toda a estrutura estatal é, na verdade o exercício do poder por pessoas. (ALBRECHT, 2006, p.135), as quais estão sujeitas a todas as imperfeições e decadências que o homem pode chegar, conseqüentemente o Estado também se encontra passível de chegar.

Canotilho pontua que a dignidade da pessoa humana, assim como os direitos fundamentais apontam para a idéia de uma comunidade Constitucional (republicana), inclusiva. Ela seria, necessariamente, pautada pelo multiculturalismo mundividencial, religioso ou filosófico e, portanto, incompatível com uma visão reducionista da dignidade. (CANOTILHO, apud SARLET, 2005, p.39)

Face a esse constatado nexo entre Estado Social Democrático de Direito e Dignidade da pessoa humana, e ao fato de que o respeito ao povo é conseqüentemente o respeito à dignidade humana, podemos concluir que, se a qualquer grupo do corpo social for negado o regular exercício de um direito fundamental que garante, promove ou protege a sua dignidade, levando estes à 
condição de objeto da atividade estatal, podemos identificar este pretenso Estado Democrático Social de Direito como não o sendo, materialmente falando, mas apenas no aspecto formal de sua acepção.

\section{2 - Dignidade da Pessoa Humana e o racismo.}

A questão racial, no Brasil e no mundo, no âmbito da teoria dos direitos humanos, apresenta-se muito mais como uma questão de direito à dignidade (entendida como o arbítrio de conduzir a sua vida da forma planejada, sem intervenções a esse regular e legítimo exercício, desde que ao exercê-lo não inviabilize o exercício legítimo de outrem do mesmo direito), do que apenas direito à igualdade, uma vez que a dignidade emerge da humanidade igual de todas as pessoas não se confundindo com o princípio da igualdade por ter o seu objeto de compreensão com uma amplitude maior.

"Entendendo a dignidade, não apenas o simples acesso aos bens, mas sim que esse acesso seja justo e se generaliza de igual forma para todas e todos os que se encaixam na idéia abstrata de humanidade. Falar de dignidade Humana, para o professor Herrera Flores não é fazer a partir de um conceito ideal ou abstrato, para ele a dignidade é um fim material, também. Um objetivo que se concretiza no acesso igualitário e generalizado aos bens que fazem com que a vida seja digna de ser vivida." (HERRERA FLORES, 2008, p.107).

Partindo desta concepção o racismo pode ser identificado como um conjunto de mecanismos que impede o regular exercício da dignidade de determinados indivíduos em uma sociedade negando-lhes a sua inclusão no ambiente social, sua participação política livre, a sua atuação profissional respeitosa, e sua segurança pessoal e coletiva despojando o indivíduo do seu valor-fim.

O Valor da Dignidade é declaradamente, pelas Nações Unidas, atingido pelo racismo em todas as suas diversas formas, conforme diz o artigo $1^{0} \mathrm{da}$ 
Declaração das Nações Unidas para a Eliminação de Todas as Formas de Discriminação Racial o qual proclama que:

"A discriminação entre seres humanos com base em raça, cor ou origem étnica é uma ofensa à dignidade humana e deve ser condenada como uma negação dos princípios das Nações Unidas, como uma violação dos direitos humanos e das liberdades fundamentais, proclamadas na Declaração Universal dos Direitos Humanos, como um obstáculo às relações amigáveis e pacíficas entre nações e como fato capaz de perturbar a paz e a segurança entre nações."

(in Http://www.dhnet.org.br/dados/cursos/dh/cc/1/prt1.htm)

Na declaração de Durban lê-se: “ [...]o racismo e discriminação racial constituem graves violações de todos os direitos humanos (grifo nosso) e obstáculo ao pleno gozo destes direitos, e negam a verdade patente de que todos os seres humanos nascem livres e iguais em dignidade e direitos[...]" (DURBAN,2001, p.12). Assim tem-se a noção de que o racismo atenta contra todos os âmbitos da dignidade humana, isto é contra todos os direitos fundamentais.

As práticas racistas são mais facilmente perceptíveis na observação da desigual fruição dos bens socialmente necessários para uma vida digna. Em razão dessa forma explícita de constatação é que se torna tão simples vincular o racismo com a negação do direito fundamental à desigualdade. ${ }^{32}$

Em razão dessa prática de denúncia do racismo, tratamento diferenciado e desigual fruição dos bens sociais, é que se torna como difícil perceber os outros âmbitos de direitos originários da compreensão Estatal de pessoa humana, que também demandam proteção em face das práticas contemporâneas de racismo. Uma observação mais atenta dos mecanismos modernos de racismo permite constatar que se não todos, uma grande quantidade de direitos fundamentais são atingidos em função desses vários mecanismos de exclusão em razão da cor.

Apesar de ser perceptível na desigual fruição dos bens sociais necessários para a vida digna, o que implica em um estreito viés de relação entre o racismo e

\footnotetext{
${ }^{32} \mathrm{~A}$ igual dignidade de todos os homens funda a igualdade de todos. É porque cada homem é dotado da dignidade de pessoa, que todos são iguais. Assim negar a alguém a dignidade significa considerá-lo como inferior e, portanto, não mais com ser humano. (Mauer, 2005, P.81)
} 
a negação de direitos fundamentais, como o direito ao igual tratamento, não é possível ignorar a característica principal do racismo que mediante suas várias formas tem como finalidade última negar a humanidade das vítimas desta prática, humanidade esta elemento que justifica a construção da idéia de dignidade e de direitos que tutelem essa qualidade do ser humano.

Partindo da constatação de que a dignidade gera para o individuo o direito de decidir de forma autônoma sobre seus projetos existências e felicidade e, mesmo onde essa autonomia lhe faltar gera o direito de se respeitado e considerado por sua condição humana, (SARLET, 2005,p.32) podemos afirmar que os inúmeros mecanismos desenvolvidos histórica e socialmente para criação e manutenção das hierarquias raciais fazem com que o racismo, em suas diversas formas de manifestação, termine por negar ao indivíduo o exercício de suas vontades, de perseguir o seu projeto de realização e construção pessoal, nega a autonomia e o direito de auto determinação do indivíduo, em suma, lhe nega dignidade.

"A liberdade e a igualdade são faces da mesma moeda. Sem políticas de igualdade que propiciem condições para que coloquem em práticas as liberdades individuais de nada a preservação destas liberdades tem valor, Amartya Sem trás a necessidade de se discutir, não mais apenas as liberdades, mas sim, a igualdade de liberdade." (SEM apud HERRERA FLORES, 2000 , p. 44)

Assim, para Herrera, a dignidade humana se compõe da conjunção dos valores de liberdade, igualdade e vida. (HERRERA FLORES, 2000, P.63).

Esses mecanismos negavam e ainda negam em determinadas sociedades multi-culturalmente compostas, a formação de uma identidade negra positiva, a positiva valoração dos traços físicos característicos deste grupo racial. Isso faz com que sejam preconcebidos potenciais de desempenho e de reação dos membros dos grupos discriminados em determinadas circunstâncias, e mesmo em razão das variantes estruturais, nega a esse grupo a fruição de vários bens fundamentais.

No modelo de sociedade globalizada neo-liberal em que vivemos, pode-se dizer que a apropriação dos bens sociais necessários para a vida digna é 
efetuada de forma desigual o que impede à alguns o acesso ao mínimo destes bens, uma vez que a apropriação desproporcional por parte de outros termina por tornar esses bens escassos e trazendo como necessária uma injusta competição ou corrida de todos contra todos para alcançá-los.

O que se nota, neste competitivo modelo é que a desigual condição de competição resulta em uma invizibilização do indivíduo que busca a realização pessoal ou mesmo o mínimo existencial da forma como ela é idealizada e proposta a todos os "competidores"em um Estado de Democrático de Direito.

Um exemplo da forma como se dá essa invizibilização é apresentado por Conceição Lourenço, quando problematiza uma situação vivenciada por ela: a autora ao pedir uma lingerie cor da pele ela recebe uma bege que nada tem a ver com a cor de sua cutis, negra, além das lingeries a questão dos lápis e band-aid de mesma cor, também traz cotidianamente a temática do racismo naturalizado no dia- a- dia do brasileiro.(LOURENÇO, 2006, p.09/10 )

O professor Milton Santos em entrevista a um jornal de grande circulação disse certa vez que:

"Aqui é natural tratar o negro de forma subalterna. Você não tem como reclamar. Se você protesta, é visto como alguém que está perturbando o 'clima agradável' que possa existir nesse ou naquele lugar" (TURRA e VENTURI, 1995, p.61).

Nesse mesmo sentido Daniel Sarmento pontua que a realidade de discriminação racial é ignorada por muitos brasileiros para os quais esta apresenta-se como um elemento natural da nossa constituição. Daniel Sarmento pontua que o brasileiro mediano perde a capacidade de perceber criticamente essa desigualdade em razão da convivência com esta e da sua socialização neste contexto desde sua tenra idade. Em razão dessas variantes é que esta termina por encarar como normal perceber o negro sempre em posições subalternas em nossa sociedade. (2008, P.61) ${ }^{33}$

\footnotetext{
33 Nesse mesmo sentido Young pontua que : "Processes of racialization stigmatize or devalue bodies, body types, or items closely attached to bodies, such as clothing; this stigmatization and stereotyping appear in public images and in the way some people react to some others. Racialization also involves understandings of the proper of the proper work of some and its
} 
É essa formação que leva a tais praticas que naturalizam e banalizam o racismo no nosso cotidiano, permitindo que essa negação da dignidade de um determinado grupo permaneça sendo encarada como normal e não relevante a ponto de tornar-se objeto de intervenção Estatal:

"A banalização do racismo, ou seja a insensibilidade em face da constatada opressão racial a que são submetidos grupos que tem negados seus direitos sociais mais elementares como educação, habitação e saúde, visa criar a impressão de que "tudo anda bem" na sociedade, imprimindo um caráter banal às distorções sócio-econômicas entre as populações de diferentes "raças" a exemplo dos espaços de participação política, os quadros dos órgãos executivo, legislativo e judiciário, que compõe se exclusivamente de brancos, salvo raras exceções que confirmam a regra. Os que acreditam no contrário podem ser julgados "revoltosos", "inconformados" e, até mesmo, "racistas às avessas". Contra estes, a "boa sociedade" estaria legitimada a organizar vigorosas ações de repressão. Essa expansão e aceitação do racismo conduzem, inexoravelmente, à sua banalização." (MOORE, 2007,passim)

O sentido da expressão "projeto de vida" acha-se associado ao conceito de realização pessoal e às opções de que dispõe o ser humano para conduzir sua vida e alcançar o destino a que se propõe.

Os seres humanos não gozam de plena liberdade, entendida esta no plano coletivo, se, em função de tratamentos discriminatórios, carecem de condições igualitárias para encaminhar sua existência sem intervenções injustificadas na persecução de seus projetos de vida e realização pessoal. ${ }^{34}$

A Convenção sobre a Eliminação de Todas as Formas de Discriminação Racial traz essa compreensão ao afirmar que a restrição ou a anulação do projeto de vida das vítimas de racismo, discriminação e intolerância implica na redução

hierarchical status in relation to others. The stigma of blackness in America, for example, has its origins in the division of labor, namely slavery. ${ }^{33}$ The slave does hard labor under domination, from which owners accumulate profits; or the slave does servile labor to attend the needs and elevate the status of the ruling group. While chattel slavery was abolished a century and a half ago, racialized positions in the social division of labor remain. The least desirable work, the work with the lowest pay, least autonomy, and lowest status, is the hard physical work, the dirty work, and the servant work".(Young,2005, p.14).

${ }^{34}$ Definição de projeto de vida do Anteprojeto de Convenção Interamericana Contra o Racismo e toda Forma de Discriminação e Intolerância. Assembléia Geral de 03 à 05 de junho de 2007. 
objetiva de suas liberdades fundamentais, a perda de um valor existencial inerente à sua dignidade e a violação de seus direitos humanos.

O privilégio branco ${ }^{35}$, presente em sociedades hierarquizadas racialmente, garante a idéia de humanidade apenas para os grupos raciais dominantes, a exemplo do grupo branco no Brasil. A imagem de humano normal é exclusiva destes e ela é a base utilizada para a construção de personagens do dia-a-dia na mídia, na escola, nas lojas, nos espaços de prestígio e em outros locais de relações sociais. Faz parte como inerente de estruturas institucionais que fazem com que os brancos sintam-se confortáveis enquanto os negros sentem-se, nesses mesmos espaços, sem confiança por não possuírem esse capital social no momento de competição, a branquidade.

O direito à identidade positiva, ainda não declarado como um direito fundamental e reclamado também por afro-descendentes ao redor do mundo, é um dos direitos atingidos pelo racismo, na sua manifestação cotidiana enquanto Privilégio Branco. Esse direito é uma expressão de um direito abarcado pela idéia de dignidade humana, uma vez que o processo de formação de identidade parece ser alcançado no âmbito de uma liberdade enquadrada em uma determinada "moldura". Essa moldura é, em parte, também a "superestrutura" jurídica da sociedade. Por meio dela o princípio da dignidade humana transmite ao indivíduo determinadas "concepções normativas a respeito da pessoa", que por sua vez, são impregnadas pela cultura de onde surgiram, é por essa razão que determinados componentes fundamentais da personalidade humana devem ser levados em consideração em todas as culturas, representam assim um conceito de dignidade insuscetível de redução culturalmente específica. (HARBLE, 2005, p.126). É por essa razão que a dignidade possui uma referencia cultural relativa, ela se situa no contexto cultural, possuindo, contudo, também feições tendencialmente universais.

A fundamentação deste direito de identidade, no momento, encontra guarda judicial apenas no princípio da dignidade, que demanda o respeito a integridade do homem não tomada apenas em sua acepção de integridade física, mas em dimensões que vão além do físico, incluindo o direito de positiva

\footnotetext{
${ }^{35}$ White privilege is like an invisible weightless knapsack of special provisions, maps, passports, codebooks, visas, clothes, tools, and blank checks. (MCINTOSH,1990,p.01)
} 
identidade, por isso que fundamentar e identificar a dignidade ainda apresenta-se como relevante uma vez que nem todas as possibilidades de agressão foram ainda identificadas e reconhecidas pelos ordenamentos jurídicos.

Toda a racialização espelha um ethos cultural, ( caráter peculiar de cada povo) pretendendo determinar quem é humano e quem não é. Distingue quem tem traços marcadamente fora do padrão e quem é considerado normal; a condição de branco, normal, o privilégio de ignorar outras culturas sem ser penalizado por isso é uma forma naturalizada de negar a humanidade dos grupos não brancos.

A naturalização desta negação de humanidade, que relativiza a dignidade de alguns, concebendo escalas e diferentes intensidades de direitos entre as pessoas, é uma forma de agressão à dignidade para a qual o Estado brasileiro não desenvolveu ainda políticas de proteção. Tal ocorre porque reconhecer isso implica em reconhecer um âmbito de participação nas desigualdades raciais de responsabilidade de todos, que passam a sentirem-se "culpados" por essas desigualdades resultantes de privilégios, os quais eles desconhecem que desfrutam, mas desfrutam.

É interessante constatar que a forma como foram tratados os Afrodescendentes no mundo não gerou indignação mundial, apenas a coisificação de pessoas de pele branca gerou a necessária unidade de países com a finalidade de criar normas internacionais que protegessem o indivíduo dessa condição, talvez apenas isso explique porque o regime do Aparthaid conseguiu estruturar-se tão completamente, a tolerância mundial em face da natural não humanidade do ser humano de pele escura.

Antonio Sergio traz que a naturalização de hierarquia sociais dá-se de diversas formas, no entanto esse termo em sentido amplo traz a idéia de uma ordem a-histórica, isenta de interesses contingentes e particulares, representando apenas atributos gerais das espécies humanas ou das divindades. (GUIMARÃES, 1999, p.30).

Essa forma de violência não-física é também a negativa de valor a uma forma de ser ou de viver, e é ela que está por trás das formas de tratamento degradante e insultuoso a certas pessoas e grupos, pois promove o desrespeito 
por formas individuais ou coletivas de viver. Para os indivíduos, portanto, a experiência dessa desvalorização social traz consigo normalmente uma perda da auto-estima, da oportunidade de se enxergarem como seres cujos traços e habilidades devem ser estimados. (HONNETH apud LOPES, 2005, p.75/76).

O maior reflexo dessa busca pelo negro de se valer também do privilégio branco, que ele identifica, é o processo de branqueamento. Uma considerável maioria do país se submete, seja alisando o cabelo, usando cremes clareadores, raspando a cabeça no caso dos homens. Essas são as expressões de uma busca negra de assimilação ${ }^{36}$ social, e conseqüente aceitação e integração, sócio, político e econômica, em uma sociedade que declaradamente não os aceita. Espera que seus membros não discutam religião em público, não explicitem a sua orientação sexual, alisem o cabelo e façam regime, e encara com naturalidade a discriminação dos que não se dedicam a esse padrão ou não conseguem esse padrão.

O professor Milton Santos em rara oportunidade em que se inseriu nesse debate pontuou que a grande aspiração do homem negro no Brasil é a de ser tratado como um homem "comum" [aspas nossa]. (TURRA e VENTURI, 1995, p. 63). É em razão das diversas formas como se manifesta no Brasil e dos vários mecanismos de que se vale, negando de forma ampla a condição de "homem comum" aos não brancos é que o anti -racismo brasileiro apresenta-se como uma demanda por justiça tanto na modalidade de reconhecimento como na modalidade de distribuição.(SARMENTO,2007, p.117).

A tese da dignidade como complemento à tese ontológico biológica da dignidade trás a necessidade de percepção da unicidade de cada pessoa humana sendo essa credora de respeito e proteção igual. Ela assim, a dignidade, passa a ser identificada como a qualidade intrínseca a pessoa, ou a dignidade como reconhecimento. Hegel e Kant já traziam esse valor como coerente apenas no

${ }^{36} \mathrm{Em}$ seu artigo Covering o professor Kenji Yoshino fala que assimilação é a mágica no sonho moderno, mágica que permite as pessoas tornarem-se mais bonitas, melhores, implica em render a sua individualidade para adentrar em determinadas comunidades. Essa busca de assimilação é na verdade o esforço de pessoas que carregam estigmas sociais em não torná-los ameaçadoramente grandes. Essa demanda social de "covering" esses estigmas, afim de torná-los menos visíveis/incomodos ao padrão do grupo dominante, é identificada pelo professor como um cotidiano ataque aos direitos de liberdade (Civil Rights), dos que desejam apresentarem-se como são sem terem suas vidas profissionais prejudicadas ou suas possibilidades de emprego cerceadas. 
âmbito das relações humanas, intersubjetivas, mediante o reconhecimento recíproco da condição de pessoa, essa noção de dignidade como reconhecimento atualmente ocupa um espaço privilegiado nos debates políticos, sociológicos e filosófico. (SARLET, 2005, p.26)

O racismo enquanto doutrina determinista equiparou a vontade e determinadas ações de uma pessoa a outras propriedades delas, propriedades as quais essas não possuem controle, como a cor da pele, dos olhos, e cabelo, entre outras. (NINO, 1989, p.271 e sgs).

Se a dignidade, como princípio, prescreve que os homens devem ser tratados segundo suas decisões, intenções e manifestações de consentimento permitindo que estes elejam e materializem seus conceitos de bem, desenvolvendo e os seus potenciais e o racismo afeta o regular exercício dessas condutas, uma vez que em sociedades racistas a cor da pele e os fenótipos são utilizados como marcadores de posição e status fazendo com que os descendentes visíveis de africanos sejam colocados em situação de desprivilegio. Podemos afirmar que não importa como o racismo se manifesta e qual o tipo de racismo se manifesta o resultado deste em suas várias formas e manifestações é um só: negar a condição humana, conseqüentemente a dignidade humana dos grupos atingidos pelas condutas racistas bem como tornar uma organização social irreconhecível como tal uma vez que somente é organizada uma sociedade quando esta permite que seus indivíduos não sejam vítimas de injustiças que inviabilizem o gozo de sua dignidade.

Por se manifestar enquanto expressão da autonomia da pessoa humana (auto- determinação e decisões a respeito da própria existência) bem como da necessidade de sua proteção por parte da comunidade e Estado quando fragilizada ou ausente a capacidade de auto -determinação. (SARLET, 2005, p.30).

No Brasil, assim como nos outros países da América onde o escravismo aconteceu, intensificou-se a prática de a-culturar o escravizado, negando-lhe o direito de constituição de família, bem como de manutenção de seus valores culturais e de sua identidade. Isso tudo somado ao trabalho forçado e ao caráter empresarial destas praticas, tornou o escravismo um dos sistemas mais cruéis que se tem conhecimento na história da humanidade. Ele é diferente do modelo 
de escravidão descrito na Grécia antiga, ou mesmo o narrado nos relatos bíblicos, dos Hebreus no Egito, porque a escravidão no Brasil teve um caráter empresarial e aculturador, negador da humanidade além de basear-se na exploração do trabalho. (Schwarcz, 1996, passim).

A redução do homem africano e de seu descendente à condição de objeto, reconhecida pelo estado, naturalizou a negação de sua dignidade humana na constituição das instituições que formaram a sociedade brasileira.

Assim, o descendente de africano, por não ter efetiva liberdade nas suas ações, condicionadas pela sua herança genética na concepção dessa doutrina, não podia ter-lhe atribuída responsabilidade pelos seus atos, logo, devia ser tutelado constantemente pelo Estado.

$\mathrm{Na}$ História do país, podemos perceber desde o início uma inerente negação da dignidade do africano, justificativa que legitimou sua vinda para o país nas condições em que foram trazidos. Essa condição, de não humano, conseqüentemente, de não merecedor de dignidade, foi em nossa sociedade, transmitida para os descendentes de africanos que por serem descendentes de seres não humanos, logo, não humanos também eram.

O Africano e o seu descendente no Brasil tinham o status de objetos, seres semoventes, passíveis de registro em cartório de bens, compra e venda, ou de reclamação de indenização, caso alguém causasse dano ao escravo de outrem.

É certo que o fim da escravidão não atribui aos africanos e seus descendentes uma dignidade que eles não tinham, mas sim, reconheceu a dignidade que lhes constituiu sempre e que havia sido injustamente negada. No entanto, mesmo após a abolição essa concepção do descendente de africano como não humano, ou menos humano não foi desconstruída completamente.

As políticas públicas elaboradas formaram instituições a fim de que os africanos, menos humanos no senso comum, deixassem de existir na sociedade brasileira, a qual pretendia se configurar sem os traços africanos, uma vez que estes ainda eram vistos como seres bestiais e como resquício indesejável que o país trazia do longo período de escravidão. 
No modelo de racismo percebido e mais combatido neste século XXI, institucional e estrutural, ainda permanece a sua característica mais marcante que é fazer com que as suas vítimas tenham suas vidas confinadas e conformadas por forças e barreiras que impedem o livre exercício de seus projetos de vida individual, negando-Ihes a dignidade.

As instituições fundadas a partir destes valores de negativa de dignidade para determinados grupos e confinamento dos mesmos, em nenhum momento foram por essa perspectiva questionadas ou reformuladas durante o pós-abolição do pais.

Ora, tais instituições não se estruturaram a ainda não se estruturam de forma a preservar o núcleo mínimo de valores necessários ao desenvolvimento da pessoa permitindo o seu livre arbítrio.

Todas as formas de manifestação de discriminação, racismo e preconceito são indignas e, conseqüentemente, num Estado Democrático de Direito, são consideradas antijurídicas e injustas:

"Social injustice exists when the combined operation of actions in institutions limit some person's opportunities to enact their morally legitimate plans because they suffer under a systematic threat of domination or deprivation of the means to develop and exercise their capacities, at the same time as they enable others to dominate or give them access to an abundance of resources." (YOUNG, 2004, p.11).

Se um estado compromete-se com a igual proteção de todos os seus membros, dignidade humana e democracia, como explicar a tolerância às violências cotidianas cometidas sistematicamente a determinados grupos no Brasil e a ausência de uma política específica para eliminar essa construção histórica percebida e repudiada pelo Estado? 


\section{CAPITULO 3}

\section{DIREITO PENAL E RELAÇÕES RACIAIS NO BRASIL.}

Num primeiro momento, esboçamos um panorama sobre a discriminação e o racismo no mundo, apresentando e definindo conceitos. Nosso intuito foi, com isso, o de demonstrar a natureza peculiar e complexa do racismo e seus mecanismos no Brasil, em razão das características fundantes do Estado e da aceitação a-crítica, pela maioria da população do país, do mito da democracia racial. Esse popularizado mito leva ao senso comum o debate sobre relações raciais, raça e racismo no Brasil, pois não permite a inserção de novas informações e explicações sobre os mecanismos que resultam na desigualdade racial, vez que não reconhece a presença dessa desigualdade em nossa sociedade.

Até mesmo nos espaços acadêmicos predomina um entendimento limitado do racismo em razão dessa ideologia e seus mecanismos. Essa percepção reduzida sobre o fenômeno do racismo no Brasil leva os formadores de opinião "científica" dos dias atuais a reafirmarem seguidamente a inexistência do racismo ou a de um tipo de racismo num grau tal que justifique a intervenção Estatal.

Neste momento, apresentaremos as teorias criminológicas e o racismo contextualizados na realidade histórica nacional. Nesse sentido, buscaremos identificar as implicações destas categorias na elaboração dos projetos de política criminal e controle social idealizados na fundação do Estado Brasileiro. Iremos, 
também, apontar como a ausência de políticas afirmativas no Sistema Penal, que tenham por finalidade eliminar, ou ao menos neutralizar, essas percepções racialmente estruturadas do crime, criminalidade, criminoso, e funções do sistema penal, condiciona o funcionamento seletivo do sistema ainda hoje.

Esse olhar histórico é necessário uma vez que a compreensão estrutural do racismo entende que os fatos históricos não justificam a intervenção nos dias atuais, mas explicam como surgiram e permaneceram os mecanismos de exclusão que surgiram no passado e reproduzem-se com naturalidade nas interações cotidianas até os dias atuais:

"To be sure, such backward looking condemnation and sanction may have a forward looking purpose as well; often it aims to deter others from similar action in the future, or to identify weak points in an institutional system that allows or encourages such blameworthy actions, in order to reform institutions. (2004, P22)

The purpose of such analysis of past events, actions, and policies and their effects, however, is not to locate perpetrators. Rather, it is to understand how particular actions, policies and intentions aggregate in structural processes to produce effects often beyond those intentions, and thus to reason about how to alter those processes". (2004, P23)

3.1. Realidade racial brasileira e a recepção e incorporação das teorias criminológicas positivistas no Brasil.

\subsection{1- Contexto de recepção das teorias criminológicas no Brasil.}

Num amplo quadro de transformação e modernização da sociedade brasileira, com o processo que culminou na Lei Áurea, em 1888, e o fim do Império, em 1889, bem como num momento de ajuste do controle social a essas transformações foi recepcionada a criminologia como Ciência no país. Essas transformações demandavam uma redefinição do tipo de ordem, concepções 
sobre cidadania e Estado eram os mais adequados para o Brasil que estava por ser planejado e constituído.

Esta introdução da criminologia como ciência no Brasil foi caracterizada pela disputa do monopólio da verdade sobre a "natureza humana" e o direito de intervenção na sociedade entre Clássicos e Positivistas (RIBEIRO, 1995, p.43). Ambas as escolas inseriram-se no processo de racionalização e desenvolvimento do Direito Penal no país, que se caracterizou pela crescente especialização dos profissionais. As diferentes concepções destas escolas completaram-se nos códigos penais de 1841 e de 1891 até o código penal de $1941^{37}$.

Naquele momento histórico, o período do fim do Império e início do que ficou conhecido como "República Velha", de formação de uma sociedade industrializada e urbana, ou uma sociedade modernizada, o pensamento autoritário permanecia e essa modernização não passou de uma imposição de modelos econômicos e sociais pelas classes dominantes e pela elite política hegemônica (Ribeiro, 1995, p.43). Como conseqüência do contexto autoritário em que se processou, a modernização brasileira foi, também, um processo autoritário, no qual as classes dominantes impediram a participação popular e impuseram seus interesses.

É nesse modelo de sociedade rigidamente hierarquizada ${ }^{38}$ e autoritária, que procurava organizar a sua nova divisão do trabalho; sociedade influenciada pela ideologia católica, pelo formalismo jurídico português e pela estratificação institucionalizada, que surge a obrigação e a necessidade, para os grupos

37 A conciliação das duas escolas nos códigos penais de 1841, 1891 e 1941, segundo Carlos Antônio Costa Ribeiro Filho, pode ser apreciada como uma afirmação da "ambigüidade" da sociedade brasileira ao conciliar elementos de realidade aparentemente paradoxais. (1994, p.132).

38 Da Mata apontando o formalismo jurídico como pedra de toque das sociedades modernas rigidamente hierarquizadas traz a tradição portuguesa de formalismo, até mesmo nas formas de tratamento previstas legalmente, e de leis e decretos abrangentes e generalizadores em uma sociedade multicultural dominada pelas hierarquias sociais onde tudo tem um lugar. A importada categorização social, mouros e judeus tiveram o seu controle agudo nas sociedades lusitanas quando não brutal á exemplo dos Judeus, contrariando a construção Freyriana que o contato com estrangeiros formara um caráter predisposto à interação aberta e igualitária, denota uma sociedade familiarizada com formas de segregação social, marcada pela ordem racial e religiosa. 
dominantes, de abandono do trabalho escravo e de construção de uma nova ideologia que mantivesse a hierarquização escravista intacta.

A substituição da mão-de-obra foi um processo complexo. Para Gebara (citado por ALVAREZ, 2003), a Lei do Ventre Livre foi o marco, o início da intervenção do Estado nesse campo, o campo da mão-de-obra nacional (p.54). É a partir desse momento que se definem as estratégias da elite para controlar a transição que implicava, não somente a incorporação do imigrante e do liberto, mas o surgimento de novas camadas sociais que emergiam com a diversificação da estrutura social, principalmente nos grandes centros urbanos como São Paulo e Rio de janeiro.

Naquele momento, além da substituição da mão-de-obra, que implicava em mudança econômica, tivemos também um processo cultural e social de transformação. Não só surgiram como necessárias formas institucionais de coerção e violência que obrigassem ao trabalho assalariado, mas também transformações que valorizassem esse trabalho.

Nas grandes metrópoles européias, o medo das elites face aos perigos resultantes das novas formas de vida no meio urbano traduziu-se em uma preocupação com o crime e a criminalidade. Assim, o crime passou a ser visto como uma das conseqüências da urbanização, associado à pobreza e à condição de vida do proletariado. Essa mesma preocupação manifestou-se na sociedade brasileira, onde as transformações sociais do meio urbano também iriam ser identificadas com uma mudança do perfil da criminalidade.

O que tornava a situação deveras preocupante, do ponto de vista das elites, eram os perigos inerentes ao acelerado processo de urbanização, pois juntavam-se àqueles colocados pelas peculiaridades do país. O passado escravista com a sua conseqüente herança de profundas desigualdades, a diversidade racial que impedia a formação de uma população almejada, similar à européia, e ainda a (assim constatada naquele momento) ausência de formação moral da população, resultado da mistura de grupos raciais diversos e da presença desses grupos raciais atavicamente amorais, eram encarados pelas elites como verdadeiros obstáculos à constituição do novo regime político e social. 
As estratégias utilizadas no processo de libertação dos escravos negros brasileiros $^{39}$ permitiram que se processassem mudanças sem rupturas violentas, viabilizando a equação de uma sociedade liberal, que por aqui se cogitava, com a ausência de eqüidade. Parte do esforço, intelectual e político da busca pela convergência e conciliação de condições tão díspares foi resolvido no âmbito do Controle Social (ALVAREZ 2003, p.06), formando um aparelho de Estado violento como suporte a essas ambições de não-ruptura. Essas instituições, que segregaram e mantiveram a ordem hierárquica, preconizaram o que hoje identificamos como racismo institucional.

Sob o ponto de vista do controle social da massa interessava à elite preservar a relação de exploração do trabalho negro, o que passaria a depender não mais de medidas presentes dentro da unidade produtiva, mas sim fora destas, mantendo o ex-escravo vigiado, controlado e tutelado, garantindo uma permanência na operatividade do novo sistema idealizado e recepcionado de práticas punitivas nascidas com o escravismo, que subordinavam e relacionavam as populações "não-brancas" ao controle social.

O Estado brasileiro, naquele momento, estabeleceu uma ordem política e jurídica que, por meio da força e da violência produziria leis e políticas estatais reprodutoras dos papéis sociais de mando e submissão. Assim, o aparelho de Estado aparece como um dos realizadores de uma violência material e institucional, estratificando e segregando, preconizando aquilo que chamamos na atualidade de racismo institucional. (BERNANRDO, 2006, p.113).

O jurista Paulo Egídio, ao comentar a Legislação Criminal do Império em obra publicada em $1900^{40}$ deixa transparecer que, para as elites imperiais, o escravo era a principal ameaça à ordem social. Ante isso, o último recurso para manutenção da ordem era a violência extrema, como explica ao justificar a manutenção da pena de morte no referido Código.

\footnotetext{
${ }^{39}$ Notório é que a libertação dos escravos foi um processo e não um evento datado do dia 13 de maio de 1988.

${ }^{40}$ EGÍDIO, Paulo. Estudos de sociologia criminal: do conceito geral do crime segundo o método contemporâneo (a propósito da teoria de E. Durkheim). São Paulo, Tipografia e Edição da Casa Eclética. 1900.
} 


\begin{abstract}
"Era necessário conservar-se essa pena, argumentavam seus sustentadores, como a única medida repressiva que, em um país desprovido de prisões seguras e de um regular sistema penitenciário, podia só conter os grandes celerados, os grandes facínoras. Outro elemento social, porém, existia no país, que, podendo ser um fator permanente de criminalidade, só podia também ser contido pela pena eliminadora: era o elemento servil, derramado em vasta escala pela superfície do país. Foi esta condição social que mais preponderou na conservação da pena capital" (p.292-293).
\end{abstract}

No período do Império, os obstáculos legais, explícitos e dissimulados, de acesso dos ex-escravos ao emprego, fosse ele público ou privado, levavam um contingente desses semi-cidadãos a serem tipificados na lei contra a vadiagem, pois o Estado brasileiro encarava esta questão como um assunto de segurança pública, enquadrando esses não-empregados negros na categoria de potenciais perturbadores da ordem, devendo, portanto, serem reprimidos. O Artigo $1^{\circ}$ do decreto de 11.12.1830 explicita esse viés racial ao deixar patente que apenas os vadios que não pudessem prover sua subsistência seriam molestados pela aplicação da norma.

O Controle físico do ex-escravo ao passar da unidade de produção, isto é, do âmbito privado e da competência do senhor de engenho para o espaço público permaneceu com a mesma natureza negadora de dignidade deste grupo, os desmandos senhoriais então passaram a ser exercidos com naturalidade pela polícia urbana em sua atuação cotidiana.

Relevante destacar o desinteresse do Estado na integração desses exescravos, como ficou demonstrado quando da importação massiva de imigrantes europeus beneficiados com estímulos financeiros iniciais para a capacitação à incipiente indústria ou agricultura, atividades em que seriam inseridos. Os escravos, nesse período, que, por meio de brechas legais, conseguiam escapar do regime que Ihes negava dignidade, eram levados, em sua maioria, à condição de réus, salvo quando "adotados" por alguém que lhes assegurava as bases estruturantes necessárias para a sua devida integração na sociedade que, 
propositalmente, os excluía. Para o Estado, esses ex-escravos passavam a ser apenas delinqüentes e perturbadores da ordem pública. (VIEIRA JUNIOR, 2006, p.90).

Constatamos, assim, a discriminação latente no texto da lei, afinal, o vadio com renda, o nobre ou bem-nascido, não era considerado criminoso. Já o exescravo, o liberto, que tendo obtido de alguma maneira sua liberdade sem poder contar com o suporte do Estado na sua tentativa de atravessar o abismo que separava a vida na escravidão da vida em liberdade, principalmente no que concerne a um auxílio financeiro inicial para subsistência e a capacitação com a finalidade de ingresso no mercado de trabalho livre, era considerado vadio, criminoso e sujeito à perseguição do Estado.

O centro de gravidade do racismo deslocou-se das páginas da lei para os aparatos de segurança, policiamento e penal, passando do reino do racismo explicitamente legalizado para formas rotineiras, porém altamente coercitivas e intimidantes, de racismo institucional. (MUSUMECI, 2005, p.235). No Brasil, o rígido Controle Social apresentava, já naquele período, características de manutenção de uma estrutura verticalmente perversa, onde a apropriação do trabalho escravo, ou ex-escravo e livre, podia se dar de forma plena pelos agricultores, então donos de vastas extensões de terras.

Foi nesse contexto que a criminologia passou a ser vista como um instrumento essencial para a viabilização dos mecanismos de controle social necessários à contenção da criminalidade local. E não somente isto: no interior do saber jurídico do Brasil, o discurso criminológico incorporou a proposta de um tratamento jurídico diferenciado para determinados setores da população, estabelecendo assim diferentes critérios de cidadania.

Segundo Adorno, as elites políticas do Império, diante das reivindicações igualitárias, estabeleceram uma complexa estrutura de poder na qual a afirmação dos ideais liberais deveria caminhar junto com a manutenção das desigualdades sociais $^{41}$. A cisão consolidada no Império, entre os princípios liberais e os valores democráticos, estabeleceu a nossa complexa estrutura social, onde o poder

\footnotetext{
${ }^{41}$ Apud ALVAREZ, Marcos C. Op. cit., p.4.
} 
permite-se afirmar os ideais liberais e, ao mesmo tempo, manter as desigualdades sociais, viabilizando-as e naturalizando-as até os dias de hoje no país.

Perante um liberalismo local totalmente divorciado dos ideais democráticos, a criminologia, enquanto discurso da desigualdade por excelência perante a lei, encontra um vasto campo de desenvolvimento ${ }^{42}$, permitindo conciliar os inúmeros impulsos contraditórios da nossa sociedade sem criar para ela um plano de transformação e conciliação.

A recepção das teorias criminológicas foi vista por muitos juristas como a possibilidade de reforma das instituições jurídico-penais conforme os ideais da escola positivista, uma vez que esta escola estava em seu auge no período da proclamação da República do Brasil e deitava suas raízes numa matriz racista de concepção do homem. Para esses teóricos, as mudanças pelas quais a sociedade passava e a necessidade de as elites nacionais criarem mecanismos para racionalizar ideologicamente as diferenças internas do país, tornavam necessárias novas formas de exercício do poder de punir. (DA MATA,1981, p.68)

O Código Penal de 1890, com sua concepção notadamente clássica em termos de doutrina penal, representou, em parte, uma ruptura com as práticas penais do passado escravista, ao instituir a generalidade e a imparcialidade dos critérios penais. Todavia, a aplicação desses critérios mostrou-se imediatamente inviável, haja visto perante um contexto político e social em que novas formas de desigualdade foram apresentadas. O grande desafio desse período foi a desigualdade de tratamento aos desiguais e não a ampliação da igualdade de tratamento jurídico-penal para toda a população.

A introdução da criminologia representou, naquele momento, a possibilidade simultânea de compreender as transformações sociais pelas quais passava a sociedade e de implementar estratégias específicas de controle social, bem como permitir formas diferenciadas de tratamento jurídico-penal para determinados segmentos da população. Desse modo, para adequar as práticas penais aos interesses das transformações do período, um grupo significativo de

${ }^{42}$ Idem, p. 215. 
juristas passou a abraçar os ensinamentos criminológicos da Escola Positiva Italiana.

O fato de a antropologia criminal ter ganhado impulso no Brasil e na América Latina num momento em que ela decaía na Europa possivelmente facilitou o reconhecimento dos autores que, no Brasil, de forma atrasada, tornavam-se seguidores de tais teorias popularizando-as. Se Lombroso não mais encontrava ampla repercussão na Europa para suas teses, na América Latina estas encontravam um grande número de entusiastas dispostos a divulgá-las e colocá-las em prática.

Não podemos, no entanto, caracterizar a presença da antropologia e da sociologia criminal como somente mais um caso de importação de idéias, pois essas novas teorias respondiam perfeitamente aos anseios e urgências históricas que se colocavam para alguns setores da elite nacional e marcaram profundamente o modelo de controle social brasileiro.

\subsection{2- Clássicos e positivistas no Brasil.}

É certo que só com o positivismo ganhou a criminologia consciência de si, contudo, a Escola Clássica tornou pela primeira ${ }^{43}$ vez possível referenciar uma reflexão sistemática e coerente sobre o problema do crime.

É a natureza sistemática e coerente de reflexão sobre o crime que permite identificá - la com o início da nova Ciência, é a ausência de dimensão sistemática que impede a possibilidade de se falar em criminologia antes da escola clássica; contudo, a história e a antropologia cultural demonstram que o crime constituiu preocupação de todas as sociedades desde os primórdios destas.

\footnotetext{
${ }^{43}$ Dentre os autores anteriores à escola clássica alguns há de resto, que merecem referencia conforme coloca Manuel da Costa Andrade e Jorge Figueiredo Dias (p.07, 1997), são esses: Platão, que viu o crime como uma doença; Aristóteles o qual considerava o criminoso um inimigo da sociedade, que deveria ser castigado; São Tomas via na miséria a causa do crime; Morus, o qual consideraria o crime um reflexo da própria sociedade; por ultimo, B. Della Porte, considerado o fundador da fisionomia, concluiu pela existência de conexões entre a forma do rosto e o crime, assim abrindo as portas às teorias que mais tarde seriam defendidas.
} 
A escola clássica caracterizou-se por ter projetado sobre o problema do crime os ideais filosóficos e o "ethos" político do humanismo racionalista. Para os teóricos desta corrente criminológica, o principal objetivo do direito criminal e da Ciência criminal é prevenir os abusos por parte das autoridades; pressuposta a racionalidade do homem, haveria apenas que indagar sobre a eventual irracionalidade das estruturas de controle, isto é a lei. O crime deveria ser compreendido não como uma entidade de fato mas sim como uma entidade de Direito. Em suma, a principal característica dos clássicos era a defesa do livre arbítrio absoluto.

Em contrapartida, para os teóricos positivistas o homem não era um ser racional agindo livremente, mas sim produto de um meio genético. Enquanto os clássicos viam o mundo de forma maniqueísta - bons e maus -, os positivistas apontavam um continuum no qual existiriam diferentes graus de criminalidade e maldade. "O crime deixava de ser uma questão moral como para os clássicos e passava a ser uma questão médica, psicológica e sociológica." (Ribeiro, 1995, p.47)

A pergunta com que se deparava a escola positiva era "por que motivo faz o delinqüente o que faz?" Essa escola tinha a criminalidade como uma realidade ontológica pré-constituída. O primeiro célebre cientista a tratar desta questão foi Cesare Lombroso. Para ele, a violência identificada como individual imunizava as possíveis relações e questionamentos entre criminalidade e violências estrutural e institucional.

Lombroso pressupunha um conjunto de estigmas biológicos e anatômicos que caracterizariam o criminoso e revelariam nele a reminiscência de um nível inferior da escala do desenvolvimento humano ${ }^{44}$. Era uma espécie de determinismo biológico que marcava profundamente essas pessoas tidas como sub-humanas. O criminoso nato, apresentar-se-ia como um tipo humano especial, intermediário entre o louco e o selvagem, produto de anomalias verificáveis no

44 "O modelo de LOMBROSO aproxima-se, portanto, como já se observou, ao modelo proposto por CUVIER, da hierarquia dos tipos raciais, e por seu discípulo SMITH, da recapitulação embrionária. Como afirma ZAFFARONI, LOMBROSO está mais próximo de GOBINEAU do que do evolucionismo de DARWIN ESPENCER (1988, p. 167). Ou seja, LOMBROSO defende a vertente pessimista da teoria dos tipos raciais, que se baseava na idéia de decadência ou degeneração das raças principais.” (Duarte, p.114) 
cérebro, o que o levaria a reproduzir na sua pessoa os instintos ferozes da humanidade primitiva. Estas anomalias, segundo Lombroso, proviriam em parte da degeneração e em parte do atavismo, o criminoso atávico, exteriormente reconhecível $^{45}$, corresponderia a um homem menos civilizado que os seus contemporâneos, representando um enorme anacronismo, um indivíduo cuja ontogênese não obedece aos ritmos de evolução da filogênese.

Conforme colocou brilhantemente Zaffaroni:

"En síntesis, podría decirse que, para Lombroso, la humanidad sería un gigantestesco organismo en trasformación cuyas células más evolucionadasy diferenciadas serían las europeas, y las más atrasadas, las colonizadas periféricas, pero que, as veces, po razones que respondían al azar boloógico, en medio de los tejidos más nobles surgían células análogas a las de los tejidos más atrasados, que era necesario depurar porque agredían a las restantes, dañando la función rectora del tejido superior." (Zaffaroni, 1988, p.163).

No prefácio da Quarta edição de sua obra O Homem Delinqüente, Lombroso já demonstrava a tendência racista que sua obra teria, ao tentar esclarecer que nem todos os povos propensos ao crime possuem todos os estigmas $^{46}$, escrevendo que “...as anomalias atávicas não se encontram todas com a mesma abundância nas raças mais selvagens; mais freqüentes nestas entretanto do que em povos mais civilizados, elas variam na proporção, sem que

\footnotetext{
${ }^{45}$ Interessante é notar a sempre presente influencia de Lombroso, a qual ultrapassa os séculos a chega até os dias atuais como demonstra essa conclusão expressa em The Times, de 11 de outubro de 1935: "A pessoa gorda, diz um Juiz, não escreve cartas anônimas. São os magros que se sentam às secretárias, como são os dedos ossudos que mergulham as canetas no vitríolo e constroem bombas para que os inocentes carteiros as distribuam" (MANNHEIM, p.315).

${ }^{46}$ Não devemos, alias, esquecer que a representação do criminoso como um ser exteriormente reconhecível, através de determinados estigmas, corresponde a um dos estereótipos mais antigos e mais duradouros da experiência humana. Estereótipos que freqüentemente afloram em obras como o Thersides ( de Homero), o Ricardo III e Machbeth (de Shakespeare), o Jacques Lantier (de Zola), o Luis da Cunha (de Camilo), Oscar Wilde em "O Retrato de Dorian Grey" , R.L. Stevenson em "O Médico e o Monstro", neste aflorando a dicotomia da alma em suas partes "boa" e "má" (Doutor Jelkyll e Mr. Hyde), Asua, que sugeria a vinculação da "tendência para o mal" àquela imagem platônica da alma puxada por dois cavalos: o negro - dos maus instintos, e o branco - da bondade! Aristóteles que estabelecia uma correlação entre o físico e o psíquico, entre a aparência e a alma, tanto que teria aconselhado Alexandre a que escolhesse os seus ministros pela fisionomia. Trechos do pronunciamento no $1^{\circ}$ Encontro Nacional de Execução Penal, Brasília, agosto de 1998. "Classificação e triagem dos condenados". Proferido por Joazil M. Gardés. Disponível em : http://www.neofito.com.br/artigos/art01/penal59.htm. Acesso em 21/10/2004.
} 
a ausência de uma ou de outra possa ser vista como marca de maior inferioridade na raça. Assim, duas anomalias atávicas, o osso do Inca e a covinha ociptal, encontram-se juntas em raças semi-civilizadas como a raça americana, e são raras entre os negros, entretanto, mais bárbaros." (Lombroso, p.XXI). "O prognatismo, a cabeleira abundante, negra e crespa, a barba escassa, a pele morena, a oxicefalia, os olhos oblíquos, o crânio pequeno, a mandíbula e os zigomas desenvolvidos, a testa oblíqua, as orelhas volumosas, a analogia entre os dois sexos, uma maior envergadura - são novos caracteres, acrescidos aos necroscópios, que aproximam o delinqüente europeu do tipo australiano e mongol" (LOMBROSO, p.232), e ainda ao analisar a fisionomia dos delinqüentes coloca, "em geral, o delinqüente nato tem orelhas de abano, cabelos abundantes, barba escassa, os senos frontais e as mandíbulas enormes, queixo quadrado e proeminente, zigomas aumentados, a gesticulação freqüente, em suma um tipo parecido com o Mongol, ás vezes com o negro."( LOMBROSO, p.234) ${ }^{47}$

A concepção da Escola Positiva foi transposta com maior aceitação para a realidade brasileira e esse modelo enraizou-se profundamente nas agências do sistema penal e no senso comum. O peso das teorias e teses desta escola na cultura política brasileira pode ser avaliado pela sobrevivência, tanto no senso comum como na mentalidade de governantes e autoridades encarregadas de formular e implementar políticas públicas penais, de alguns de seus pressupostos, sobretudo aqueles que sustêm maior "potencial criminógeno" em negros do que em brancos.

As premissas da Escola Clássica encontraram dificuldades na sua aplicação de forma ampla e irrestrita no Brasil, pois o livre arbítrio absoluto, para os clássicos brasileiros, era influenciado por uma série de fatores práticos resultantes da necessidade de considerar o escravo e o negro liberto como elemento constituinte da realidade brasileira, o que fez surgir uma alternativa teórica que defendia o livre arbítrio relativo, a escola neoclássica. Essa alternativa determinava a obrigação, por parte dos juízes, de observarem as condições que reduziam a capacidade de exercício do livre arbítrio, o que fazia com que eles

47 Tradução Livre : In genere, i più fra i delinquenti - nati hanno orecchi ad ansa, capelli abbondanti, carsa la barba, seni frontali spiccati, gesticolazione frequente, tipo, insomma, somigliante al Mongolico e qualche volta al Negroide. 
tivessem de recorrer a profissionais fora do campo jurídico, tais como, psiquiatras, médicos e antropólogos. Os neoclássicos tentavam conciliar o livre arbítrio com o determinismo de um tipo específico (social e psicológico, não biológico).

Em seu artigo "Clássicos e Positivistas no moderno direito penal brasileiro: uma interpretação sociológica", bem como em seu livro Cor e Criminalidade, Carlos Antônio Costa Ribeiro ${ }^{48}$ analisa o julgamento de José Palmiere nos autos do processo criminal de $n^{\circ} 258$, maço 102, encontrado no arquivo do Primeiro Tribunal do Júri da cidade do Rio de Janeiro. O autor aponta a presença da disputa entre as duas escolas durante o desenrolar do processo, o que resultou, ao longo do mesmo, em idas e vindas em direção à concepção de criminalidade de uma escola, a positiva, à outra, a clássica. Por trás desse debate, puramente escolástico na aparência, problemas mais práticos se evidenciam. Efetivamente, estava em jogo a implantação de dispositivos normalizadores capazes de administrar as desigualdades presentes e identificadas como inerentes na sociedade brasileira, desigualdades para as quais não se vislumbravam e buscavam possibilidades de desconstrução, mas apenas de gerenciamento.

Os juristas reformadores situados no centro da tensão entre os ideais de igualdade política e social do novo regime e as desigualdades sociais percebidas como heranças constitutivas da sociedade eram exigidos no sentido de uma articulação de concepções e demandas opostas e, por que não? Contraditórias (ALVAREZ, 2003, p.214). A convivência das concepções de criminoso e criminalidade no Código Penal de então, fazia pressupor que no país existiam indivíduos recuperáveis por meio de castigos, outros que necessitariam de tratamento médico especial, e ainda aqueles que seriam irrecuperáveis.

Fatores de hierarquização, estigmatização e diferenciação, de caráter puramente sócio-culturais, contribuíam para a definição de quais indivíduos seriam castigáveis, tratáveis ou irrecuperáveis. É na hora de definir quem deveria receber um ou outro tratamento que a ambigüidade do sistema de normas penais mistura-se aos procedimentos sociais produzindo, em nome da objetividade da

${ }^{48}$ RIBEIRO, Carlos Antonio Costa. (1994) "Clássicos e Positivistas no moderno direito penal brasileiro: uma interpretação sociológica,1994, p. 130-146. 
ciência, resultados que expressam o caráter desigual e hierárquico da sociedade brasileira. (RIBEIRO, 1994, p.146).

\begin{abstract}
“(...) havia uma forte tendência de discriminação racial nos julgamentos do Tribunal do Júri. Os acusados pretos têm 38 pontos percentuais a mais de chances de condenação do que os acusados brancos, e os acusados pardos têm 20.5 pontos percentuais a mais de chances de condenação do que os acusados brancos. Por outro lado, quando a vítima é parda, o acusado tem 29.8 pontos percentuais a mais de chances de absolvição do que quando a vítima é branca, e se a vítima for preta, e não branca, o acusado tem 15.3 pontos percentuais a mais de chances de absolvição. É importante lembrar que, segundo as análises estatísticas, o fato de o acusado ser preto é o que mais aumenta as probabilidades de condenação, e o fato de a vítima ser parda ou preta é o que mais aumenta as chances de absolvição". (RIBEIRO, 1995, p.143).
\end{abstract}

Ribeiro diz que a combinação dessas idéias, classicas e positivas, se dá em uma dialética que concede uma maior liberdade aos funcionários judiciais possibilitando que esses caracterizem a partir de interesses próprios os atos das pessoas identificadas como acusadas ou suspeitas. Por interesse próprio entende-se o de vigiar, punir, condenar, absolver, amenizar ou agravar penas (1995, p.55).

O ecletismo penal brasileiro manifestou-se na tendência em apagar as diferenças entre as diversas correntes de pensamento voltadas para o problema criminal. Como resultado desta recepção conciliadora das teorias criminológicas européias, a compreensão do crime e do criminoso foi encarada, no Brasil, como um problema complexo demais para ser explicado somente pelos juristas, uma vez que, para eles, este problema também abarcava aspectos sociológicos e biológicos.

Não havia, contudo, diferenças marcantes entre os sociólogos e antropólogos da nova escola penal no Brasil, pois a crítica à concepção clássica, a defesa dos novos fundamentos do direito de punir e a necessidade de reformas das leis e instituições penais foram pontos convergentes entre os diversos autores, a despeito das localizadas divergências existentes. Nesse período de 
recepção das teorias criminológicas viabilizou-se um discurso a partir do qual os juristas puderam propor tanto reformas jurídico-penais como reformas sociais, fazendo com que alguns teóricos destas escolas vislumbrassem uma possibilidade de atuação também perante a opinião pública da época.

O fenômeno central do positivismo é o papel da ciência na sociedade, logo, o conhecimento produzido deveria estabilizar a sociedade e permitir a continuidade das crenças garantidoras desta. O discurso do racismo, que legitimava as naturais diferenças entre as raças, foi transportado para o universo de exaltação da ordem, isto é, a seara criminal. Naquele momento, a crença no binômio diferença-inferioridade era pressuposto do discurso científico-jurídico formulado.

Lombroso, de maneira simples, perguntou-se "por que os criminosos eram criminosos?", mas não preocupou-se em explicar por que afirmava que os "selvagens", os africanos, os índios da América do Sul e os Australianos eram criminosos. As suas oposições freqüentes foram sempre interpretadas no discurso como um pressuposto inquestionável do conhecimento do mais comum dos homens.

O discurso criminológico, neste sentido, conforme Charles Pizza (2002)

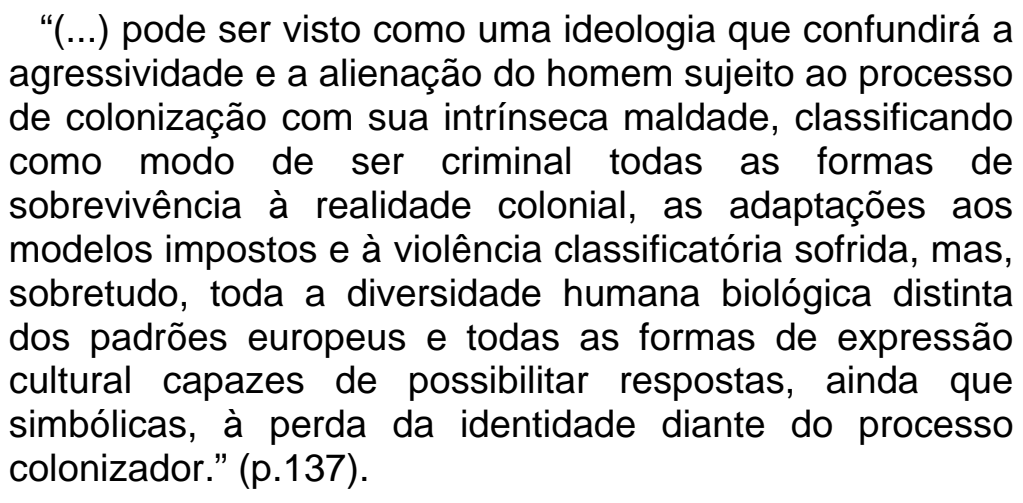

Os juristas reformadores não tentaram abrir espaço para extensão da cidadania às classes populares, mas, sim, buscaram estabelecer critérios diferenciados de tratamento jurídico e institucional, que acabaram por recolocar novas formas de dominação. A nova escola penal, com o seu saber criminológico, 
inventou uma fórmula para tornar aceitável e legítima a nova ordem que se formava no Brasil, sem alterar bases estruturais fundada na desigualdade, e estabeleceu uma conexão entre cidadania e controle social.

A tentativa de articular liberdade e propriedade, lei e democracia social, liberdade e igualdade, numa sociedade construída sobre as bases do escravismo, na qual a vontade dos senhores tudo podia - inclusive colocar-se às margens do Estado -, iniciou os conflitos, que permanecem ainda nos nossas dias, em torno de uma estrutura complexa que congregava e congrega a afirmação dos ideais liberais juntamente com a manutenção das desigualdades sociais. Os bacharéis então formados nas faculdades de Direito do Brasil, (liberais, mas não democratas) com suas peculiaridades tornaram muito fácil a articulação entre liberalismo e cientificismo (ALVAREZ, 2003, p. 217). Por esta razão, o discurso liberal não democrático conseguiu convergir com a percepção de desigualdade inerente aos cientificistas da escola criminológica positivista.

Em razão desses fatores de crise e ruptura histórica, a penetração da criminologia no Brasil representou um capítulo nada desprezível no processo de formalização das desigualdades sociais. A partir do discurso criminológico instituições foram criadas, reformas foram planejadas, diversos indivíduos tiveram suas vidas afetadas, de forma positiva ou negativa, tornando-se difícil, portanto, considerar a recepção de tais idéias como algo sem maiores desdobramentos efetivos.

O contexto histórico explicando a maneira como anunciavam-se as relações raciais no Brasil e no mundo, na lógica cruel do período já referido, foi desenvolvido nos tópicos anteriores. Portanto, não nos aprofundaremos novamente neste tema. 


\subsection{3- Os Criminologistas Brasileiros.}

Das cidades do Rio de Janeiro e São Paulo no início do século $X X, 0$ professor Marcos Cezar Alvarez destaca três autores que, considera ele, ilustram específicos aspectos da divulgação da criminologia como ciência no Brasil. Estes autores são:

Viveiros de Castro, que tentou em suas obras reproduzir no Brasil a repercussão polêmica que as idéias criminológicas ganharam na Europa, e que aparecem em seus textos como importantes símbolos da "modernidade". Este autor percebeu claramente as idéias da antropologia criminal e suas conseqüências nas instituições penais brasileiras.

Paulo Egídio, que tem como seu mais importante trabalho Estudos de Sociologia Criminal, no qual, ao contrario de outros estudos da época que didaticamente buscavam divulgar a nova escola penal, procurou analisar um autor em específico, Emile Durkheim. ALVAREZ (2003, passim) quando da análise da obra de Paulo Egídio, concluiu que este autor optou por tomar partido da escola positivista antropológica o que, na opinião deste autor, fica claro nas críticas que Paulo Egídio faz à definição de crime como um fenômeno normal.

Cândido Mota foi o responsável pela divulgação das idéias da nova escola penal na Faculdade de Direito de São Paulo. Buscou demonstrar que o foco de preocupação do combate ao crime, um mal social, não é o próprio crime, e sim o delinqüente. Enumerou várias classificações de criminosos adotando a metodologia de Enrico Ferri por acreditar ser a mais completa e, inclusive, complementar à de Lombroso. ${ }^{49}$

\footnotetext{
${ }^{49}$ A analise pormenorizada desses autores é desenvolvida na Obra: Bacharéis Criminologistas e Juristas - Saber Jurídico e Nova Escola penal no Brasil - de Marcos César Alvarez. Op cit.
} 
De acordo com ALVAREZ, estes autores divulgaram as teorias da nova escola penal positivista e usaram-nas como base para a reforma do sistema penitenciário do estado de São Paulo, criando a Penitenciaria do Estado e o Instituto Disciplinar, este a partir da aprovação do projeto de Cândido Mota. (2003, p.107).

Os estudos consideram como marco inicial da criminologia no Brasil o pensamento de Tobias Barreto e a Escola do Recife. Barreto foi o primeiro brasileiro a criticar Lombroso e teve em Silvio Romero um dos seus discípulos. $\mathrm{Na}$ sequência, os estudiosos apontam Clovis Bevilacqua, primeiro autor de um livro brasileiro de criminologia aplicada, publicado em 1896 na Bahia. Temos, então, Nina Rodrigues, médico considerado por Lombroso como o apóstolo da Antropologia Criminal na América do Sul. Rodrigues, médico da Escola Baiana, defendeu uma criminologia racista em seus livros, dentre os quais destacamos As raças humanas e a responsabilidade penal no Brasil ${ }^{50}$.

Entendemos que Nina Rodrigues situa-se como um capítulo à parte na história da criminologia no Brasil. Em seu ensaio de psicologia criminal brasileira, muito influenciado pela corrente então em surgimento, o positivismo criminológico, buscou realizar um estudo das modificações que as condições de raça imprimiam à responsabilidade penal. Rodrigues defendia que o aperfeiçoamento lento e gradual da atividade psíquica, inteligência e moral não reconhecia, de fato, outra condição além do aperfeiçoamento evolutivo da série animal e que obrigar os negros a adaptarem-se ao sistema penal das civilizações européias, "muito mais polidas e adiantadas", equivalia a "fazer um povo selvagem, ou bárbaro, transpor, no curso da vida de uma geração". ${ }^{51}$

O autor afirmava que desse modo, nas raças "inferiores" a impulsividade primitiva, fonte e origem de atos violentos e anti-sociais, por muito predominaria sobre as ações refletidas e adaptadas que só se tornaram possíveis nas raças cultas e nos povos civilizados, com o aparecimento de motivos psíquicos de uma ordem moral mais elevada e que os negros africanos pertenciam a uma outra fase

\footnotetext{
${ }^{50}$ RODRIGUES, Nina , As Raças Humanas e a Responsabilidade Penal no Brasil.- Editora livraria progresso. Salvador, 1894

51 Idem, pp, 29, 30 e 31.
} 
do desenvolvimento intelectual e moral, conseqüência de uma cerebração incompleta o que Ihes permitia conservar vivaz os instintos brutais do africano; que eram, segundo o autor, rixosos, violentos nas suas impulsões sexuais, muito dado sà embriaguez, e esse fundo de caráter imprimia o seu cunho na criminalidade colonial. Estes, concluía o autor, deveriam ter um Código Penal diferenciado ${ }^{52}$.

A professora Gislene Aparecida (1993) indicou as quatro causas pelas quais Nina Rodrigues identificava o negro como criminoso nato: 1) as raças apresentam graus de evolução, desenvolvimento, cultura e inteligência diferentes; 2) a cada grau evolutivo corresponde uma moral, portanto, não há valores universais, atemporais e uniformes que possam servir como sustentáculo para um direito universal e uma noção única de justiça; 3) uma lei universal pressupõe uma identidade total entre todos os indivíduos que compõem a sociedade; 4) não existe o livre-arbítrio. (p.134).

Importante destacar que os principais teóricos conhecidos internacionalmente como criminologistas positivistas brasileiros são também identificados como os principais teóricos do racismo científico no país. Nina Rodrigues, Euclides da Cunha, Nelson Hungria e Artur Ramos, pensando de forma não diferente do senso comum de sua época, acreditavam que negros e pobres cometiam mais crimes do que os brancos e ricos em razão de uma maior propensão biológica para o crime ou pelo fato de se encontrarem em um estágio de maior "atraso cultural"(RIBEIRO, 1995, p.143).

Evoluindo lentamente como ciência, no Brasil, a criminologia crítica tem se inserido de forma incipiente na prática cotidiana dos profissionais do Controle Social no país. As razões para este comportamento dos estudiosos brasileiros e dos gestores públicos devem ser analisadas levando-se em conta desde a opção ideológica bastante definida da criminologia crítica (com bases marxistas) até as dificuldades políticas internas enfrentadas, que ocasionaram certo isolamento cultural do único país de língua portuguesa da América Latina, passando pela formação eclética dos precursores do estudo criminológico brasileiro.

\footnotetext{
52 Idem, pp 82 e 117.
} 
O Instituto Carioca de Criminologia, tendo a frente o professor Nilo Batista, tem difundido o ideário crítico de Taylor, Walton e Young e Alessandro Baratta ${ }^{53}$, que se contrapõem ao positivismo institucionalizado e arraigado no pensamento penal e criminológico do país. Apesar das dificuldades, em razão de um regime político adverso que durou mais ou menos trinta anos, o Brasil dispõe, e podem ser apontados, criminólogos não-alinhados ideologicamente que tiveram a devida visão crítica do organismo social brasileiro. Esses criminologistas, apesar do nãoalinhamento, consideram a raça como uma variável à mais no funcionamento do controle social brasileiro e não como elemento estruturante e determinante para a compreensão do funcionamento desta instituição.

3.2. Efeitos da "retomada” destas teorias no Brasil. Tendência Político Criminal mundial, na atuação do judiciário.

É interessante e necessário apontar que tais teorias formadoras das instituições do sistema de controle social no Brasil não estão sendo retomadas, uma vez que elas nunca foram totalmente abandonadas. Estão, na verdade, sendo popularizadas e ganhando intensidade. Conforme podemos observar, o discurso crminologico positivista ainda é dominante, presente nos manuais introdutórios de Direito Penal, que ignoram a problematização do processo de recepção das teorias Criminológicas e Político-Criminais no Brasil.

O processo de formação do nosso sistema penal pós-império criou um modelo de Controle Social violento,que pode ser percebido nas criticadas práticas policiais, glorificadas e justificadas em razão dos aparentes níveis de insegurança social que são comparados aos de um conflito militar, a exemplo dos filmes nacionais dos dias atuais.

Podemos definir a ideologia dessas correntes positivistas enunciando analiticamente seus princípios. A professora Vera Regina Andrade (1994) assim os vê:

${ }^{53}$ Autores paradigmáticos na produção moderna de uma teoria em criminologia crítica ao modelo positivista. 
a) Princípio do bem e do mal. O fato punível representa um dano para a sociedade e o delinqüente é um elemento negativo e disfuncional do sistema social. O comportamento criminal desviante é o mal (comportamento de uma minoria desviada) e a sociedade o bem.

b) Princípio de culpabilidade. O fato punível é expressão de uma atitude interior reprovável, porque seu autor atua conscientemente contra valores e normas que existem na sociedade previamente à sua sanção pelo legislador.

c) Princípio de legitimidade. O Estado, como expressão da sociedade, está legitimado para, através do sistema penal, reprimir a criminalidade, da qual são responsáveis determinados indivíduos.

d) Princípio da legalidade. O Estado não apenas está legitimado para combater a criminalidade, mas é auto-limitado pelo Direito Penal no exercício desta função punitiva realizando-a no marco de uma estrita legalidade e garantia dos Direitos humanos do imputado.

e) Princípio de igualdade. O Direito Penal é igual para todos. A reação penal se aplica de igual maneira a todos os autores de delitos.

f) Princípio do interesse social e do delito natural. Os interesses que o Direito Penal protege são interesses comuns a todos os cidadãos. (p. 135-138).

Estas teorias passaram a serem questionadas em razão de um impulso de deslegitimação do sistema penal e seus paradigmas. Esse impulso deslegitimador foi levado a cabo pelo paradigma crítico que, a partir da década de sessenta, surgiu como uma proposta de desconstrução e deslegitimação do sistema penal e seus paradigmas. Esse paradigma crítico produziu resultados em duas dimensões: a dimensão propriamente desconstrutora, consubstanciada pela crítica historiográfica, sociológica e criminológica do moderno sistema penal, e a dimensão das políticas criminais alternativas e dos movimentos de reforma, a 
exemplo dos programas de medidas alternativas a pena de prisão, que a ela se seguiram e somente puderam ser pensadas a partir desta desconstrução.

Na primeira dimensão, pode-se aludir a pelo menos quatro desconstruções fundamentais, que, embora convergentes, se estruturam a partir de diferentes perspectivas analíticas: a desconstrução marxista, a desconstrução foucaultiana, a desconstrução interacionista (do "labelling aproach") e a desconstrução abolicionista (ANDRADE, 1994, p.1997)

Para Foucault (1987), numa economia política, o sistema penal somente poderia ser visto como um instrumento para gerir diferencialmente as ilegalidades e não para suprimí-las, resultando daí o fato de aplicar-se seletivamente a certos indivíduos e sempre aos mesmos. A prisão ao, aparentemente, fracassar no seu objetivo declarado de combater a criminalidade, não erra o seu objetivo, ao contrário, ela o atinge na medida em que:

“(...) contribui para estabelecer uma ilegalidade visível, marcada, irredutível a um certo nível e secretamente útil rebelde e dócil ao mesmo tempo; ela desenha, isola e sublinha uma forma de ilegalidade que parece resumir simbolicamente todas as outras, mas que permite deixar na sombra as que se quer ou que se deve tolerar. Essa forma é a delinqüência propriamente dita." (p.243)

Guardadas as suas especificidades, encontramos alguns pontos de aproximação entre a criminologia crítica e as teorias de Foucault, no que diz respeito a afirmações de que a criminalidade é produzida de forma seletiva pelo sistema e que este conceito, a criminalidade, é, na verdade, um instrumento para gerenciamento diferenciado da ilegalidade ou dos bens negativos. Ao analisarmos as obras de Foucault, percebemos que a lógica de seletividade diferenciada existe desde a fundação do sistema penal brasileiro. A lei penal configura tão só um marco abstrato de decisão, no qual os agentes do controle social formal desfrutam de ampla margem de discricionariedade na seleção que efetuam.

Shutherlend em seu clássico artigo sobre a criminalidade de colarinho branco, ao analisar dados estatísticos de vários órgãos das áreas de economia e 
comércio, constatou uma impressionante quantidade de infrações às normas praticadas por pessoas destes setores. O pesquisador trouxe uma visão mais sofisticada sobre a criminalidade do que a do paradigma etiológico da escola positivista $^{54}$, trazendo a luz do estudo sobre a criminalidade o efeito funil e de seletividade do funcionamento do sistema penal.

A revelação dessa criminalidade impune em parte desqualificou os dados estatísticos oficiais sobre a criminalidade, evidenciando que estes nada informavam sobre a real criminalidade, apenas permitiam uma visualização da qualidade da criminalização, isto é, qual o tipo de crime e de criminoso buscavase atender como clientela desse sistema seletivo.

Assim, as estatísticas criminais passam a assumir nos países periféricos apenas a função de proporcionar o conhecimento de um setor da criminalização, a criminalidade legal ${ }^{55}$, como identifica Aniyar de Castro $(1983$, p.67) trazendo uma nova dimensão científica das estatísticas oficiais. Essas estatísticas, para 0 paradigma da reação social, funcionam como um instrumento privilegiado para estudo não da criminalidade, mas, sim, da lógica do controle social, isto é, do modelo de comportamento das instâncias de controle e das suas específicas "clientelas" uma vez que

"nem todo delito cometido é perseguido, nem todo delito perseguido é registrado, nem todo delito registrado é averiguado pela polícia, nem todo delito averiguado é denunciado, nem toda denuncia é recebida e nem toda denuncia termina em condenação."(BARATTA, 1991, p.103).

Como bem disse Boris Fausto (1984)

"Certamente, o maior índice de condenação de pessoas de cor não é ocasional. Estamos diante de um produto de um tratamento discriminatório a partir de um handicap social

\footnotetext{
${ }^{54}$ Em 1939 Edwin Sutherland apresentou o seu artigo: "O Criminoso de Colarinho Branco", perante o $34^{\circ}$ Congresso da Sociedade Americana de Sociologia.

${ }^{55}$ Aniyar de Castro identifica três tipos de crimialidade que seria a legal: registrada em estatísticas oficiais, a criminalidade aparente: conhecida pelos órgãos de controle social mas não constam das estatísticas e por fim a criminalidade real, ou seja, a totalidade dos delitos cometidos na sociedade.
} 
amplo sobre o qual incide um conjunto de circunstâncias. Ou seja, não se trata apenas do preconceito genérico contra o preto; o que se tem diante dos olhos, cabisbaixo diante da imponência da sala de sessões, é um ser inferior - preto e pobre -, acusado de um delito com relação ao qual há má vontade dos julgadores leigos ou togados, defendido apenas formalmente por um advogado de circunstância." (p. 235-36)

Essa percepção de defesa formal e de que os órgãos responsáveis pela defesa dos mais pobres recebem um produto "semi-acabado", impossível de ter o seu caráter estratificado e seletivo desconstruído durante o processo, como ele se apresenta, é enfatizada na colocação da defensora pública Maria Ignez Kato durante entrevista para Ramos em seu documentário:

"A linguagem do direito é uma linguagem de dominação(...), é uma ideologia(...). O policial que qualifica o réu é que o criminaliza na medida em que ele inicia um processo a partir de seu olhar. Os juízes e promotores apenas buscam provas e contraprovas que afirmem ou desafirmem o que disse o policial" ${ }^{56}$

Sergio Adorno (1996, p.3) faz constatação semelhante e destaca que a manutenção da prisão em flagrante, dado que segundo ele inclina à condenação na sentença, é uma tendência mais acentuada para réus negros $(62,3 \%)$ do que para réus brancos $(59,2 \%)$. Para Zaffaroni $(1988$, passim) se o sistema penal concretizasse o poder criminalizante para o qual está programado provocaria uma catástrofe social, entendendo, assim, que a imunidade e não a criminalização é a regra no funcionamento do sistema criminal, estando este estruturado para que a legalidade processual não opere em toda a sua extensão ${ }^{57}$ uma vez que face à disparidade entre a atuação idealizada no plano legislativo e a capacidade operacional de seus órgãos (disponibilidade de recursos para implementação da

${ }^{56}$ Apud SÃO BERNANRDO, Augusto Sérgio dos Santos de. Identidade Racial e Direito à Diferença Xangô e Thémis. Dissertação de Mestrado. UNB. 2006. Brasília. p. 89

${ }^{57}$ HULSMAN coloca que é absurdo programar uma máquina para que esta funcione com um mau rendimento a fim de evitar que esta deixe de funcionar.(1993,p.65). Mas, em um país periférico como o Brasil, onde o sistema de Justiça tem que apresentar uma aparência de funcionalidade até mesmo para que seja eficaz em sua real função de seleção dos descendentes de africanos, essa ilógica faz todo o sentido. 
programação) este apenas mantém-se e legitima-se pressupondo uma atuação seletiva

“(...) a criminalidade não é um comportamento de uma minoria restringida, como quer uma difundida concepção (e a ideologia da defesa social ligada a ela), mas ao contrário, o comportamento de amplos estratos ou até da maioria dos membros de nossas sociedades"(BARATTA, 1991, p.103).

É nesse modelo de sistema criminal que a seletividade quantitativa ${ }^{58}$, necessária para a existência do sistema, passa a ter uma conotação também qualitativa ao longo do processo de criminalização. O funcionamento seletivo do sistema não depende apenas da defasagem denunciada entre programas de ação e recursos disponíveis, mas depende também de outra variável estrutural, a especificidade da infração e a relevância social do autor.

A distribuição seletiva do status de criminoso se dá tanto no processo de criminalização primária, momento de escolha dos bens jurídicos que a sociedade pretende defender, quanto no momento de criminalização secundária, realizado no momento de aplicação das normas penais pelos membros da Polícia, Ministério Público, e Poder Judiciário.

Numerosas são as pesquisas desenvolvidas nos últimos anos, em sua maioria associada ao paradigma da reação social, com o propósito de demonstrar como tais variáveis (etnia, condição familiar, status social, etc.) exercem influência e condicionam a seletividade decisória dos agentes do sistema penal: Polícia, Ministério Público e Juízes.

Boris Fausto, em análise dos dados referentes às prisões em São Paulo, no período compreendido entre 1880 e 1924, pontua que:

\footnotetext{
58 Apenas cinco em cada 100 boletins de ocorrência registrados na capital paulista são investigados pela polícia. Esse foi o resultado da pesquisa "Taxa de Impunidade Penal" realizada pelo Núcleo de Estudos da Violência da Universidade de São Paulo (NEV-USP). Foram pesquisados 344.767 boletins de ocorrência registrados em 16 delegacias da Zona Oeste da capital, e só $5,48 \%$ foram convertidos em inquérito policial, isto é, foram investigados pela polícia. Disponível em :

http://www.nevusp.org/portugues/index.php?option=com content\&task=view\&id=1675\&ltemid=29 acesso em 20/07/2008.
} 
"Não há nada de surpreendente no fato de que negros e mulatos contribuam com um maior peso proporcional de detenções quando se tem em conta, de um lado, o caráter contravencional da maioria destas condutas cometidas por uma maioria, mas apenas reprimidas, legal e normativamente, quando o sujeito destas condutas faz parte de um grupo que precisa ser reprimido, e, de outro, a situação de marginalidade ou subemprego a que foi confinada a população negra sobretudo a masculina - após a abolição. Por sua vez, não há dúvida de que uma discriminação avassaladora foi também responsável por estes números"(1984, p.54).

O autor chama ainda a atenção para o fato de que negros e multatos eram presos em proporção duas vezes maior do que sua representatividade na população da cidade e para o número maior de negros do que de mulatos presos, apesar da presença destes ser em proporção inversa na sociedade paulistana. Quando da análise de processos deste período e seus desfechos, é possível traçar um parecer atemporal nos efeitos que a influência do racismo no desfecho dos processos, conforme a cor do réu.

Discriminação racial é a conclusão a que chega o autor, ao constatar que no período por ele analisado, a absolvição e o arquivamento constituíam o resultado minoritário para os réus de cor preta e majoritário quando se tratava de réus de cor branca. (FAUSTO, 1984, p.235). Essa desigualdade permanece no funcionamento do sistema, conforme apontou Sérgio Adorno em sua pesquisa sobre Discriminação Racial No Sistema de Justiça Criminal, desenvolvida durante os anos noventa. $\mathrm{O}$ autor constatou que réus negros eram presos em flagrante em maior número, respondiam em menor número em liberdade aos processos criminais e eram em maior número dependentes da assistência judiciária.

Essa última constatação, uma variante explicada pelo viés do racismo estrutural, uma vez que reflete a condição sócio-econômica em conjunto com a variante racial, acentuando as desigualdades e seleções patentes do controle criminal paulistano. As duas pesquisas trazem um desfecho comum que aponta para uma maior proporção de réus negros condenados $(68,8 \%)$ em relação aos réus brancos $(59,4 \%)$, bem como o maior número de réus brancos absolvidos $(37,5 \%)$ em relação aos réus negros (31,2\%). (ADORNO, 1996, p.03) 
Adorno preocupou-se em avaliar o estrato sócio-econômico dos réus, conferindo que ambos, brancos e negros, faziam parte do mesmo grupo social, recrutados nos mesmos estratos sócio-econômicos desfavorecidos, compostos majoritariamente por grupos de trabalhadores de baixa renda, pauperizados, ao que se associa a baixa escolaridade.(1984, p.17).

Em sentido de resultados similares, com métodos de pesquisa diferentes e o mesmo objeto, o IBCCrim, em 2003 analisou sentenças proferidas em processos referentes a crimes não-violentos ${ }^{59}$. Podemos perceber, de forma nada surpreendente $^{60}$, o mesmo padrão de resultados em razão da cor, bem como do gênero, categorias a que o instituto se voltou. Os homens negros, nos dados levantados aumentavam proporcionalmente a sua representação conforme o desenrolar do processo, inversamente ao que ocorria com os brancos, o que denota um movimento antagônico no decorrer do processo penal para cada grupo. A pesquisa do instituto também constatou um maior número de inquéritos iniciados com prisões em flagrante para réus negros, enquanto a maioria dos réus brancos foi indiciada por portaria. (LIMA, TEIXEIRA\& SINHORETTO, 2003, p.3).

As conclusões apresentadas não são diferentes da que chegou Carlos Antonio Costa Ribeiro quando da sua pesquisa no Tribunal do Júri do Rio de Janeiro com processos do período compreendido entra os anos de 1900 a 1930. O autor diz em suas conclusões que era possível perceber que os acusados pretos tinham 38\% mais chances de condenação do que os acusados brancos, e os acusados pardos tinham 20,5 \% mais chances de condenação do que os acusados brancos e sendo a vítima parda o acusado tinha 29,8\% mais chances

\footnotetext{
${ }^{59}$ Existe um entendimento no sentido de que o racismo institucional é mais bem observado em crimes não-violentos, como os contra o patrimônio, trazendo o viés estrutural da concepção racial criminal que se relaciona de forma intensa com o capitalismo.

${ }^{60}$ É no mínimo inocente acreditar que uma instituição construída com valores que manteriam a sociedade hierarquizada racialmente, e que em nenhum momento da história do país teve qualquer tipo de intervenção estatal com a finalidade de desconstrução desse caráter racializado, (com exceção da previsão que encontramos no parágrafo primeiro do artigo terceiro de lei 7210/84 que prevê a aplicação da lei sem qualquer tipo de discriminação) constituinte da instituição, deixou de reproduzir esses valores parte de sua lógica de funcionamento. Não afirmamos que seria impossível uma mudança no nosso modelo de controle, seria possível tal mudança se essa fosse um reflexo de uma transformação nos valores que informam os comportamento e as relações raciais da sociedade, mas no Brasil essa alteração nas relações sociais ainda não aconteceu, somente práticas cotidianas de relações raciais hierarquizadas e com a finalidade de manutenção desta hierarquização podem explicar os números da desigualdade racial que os órgãos oficiais de Estatística apresentam.
} 
de ser absolvido do que quando a vítima é branca e sendo a vítima negra o acusado tinha o acusado tinha $15,3 \%$ mais chances de absolvição em comparação á uma vítima branca. O autor afirmava que constatada a forte tendência de discriminação racial no Júri era importante lembrar que: "o fato do acusado ser preto é o que mais aumenta as probabilidades de condenação, e o fato de a vítima ser parda ou preta é o que mais aumenta as chances de absolvição".(1995, p.143).

Ribeiro teve como estímulo para a construção do seu objeto a constatação similar em sua pesquisa sob orientação da professora Yvonne Maggie sobre os crimes de curandeirismo que:

"a maioria das pessoas acusadas nos inquéritos policiais constituam-se de brancos. Mas ao analisar um pequeno conjunto de vinte e três processos criminais julgados nos Tribunais, a antropóloga verifica que todos os condenados eram negros e que nenhum branco havia sido condenado." (1995, p.12)

Essa analise histórica permite identificar como a categoria raça, constituída na gênese do controle social mundial foi, no Brasil, tão bem absorvida na formação do nosso modelo de controle social e como a ausência desta, no presente momento, implica, do ponto de vista legal dos gestores públicos de segurança e das políticas publicas na área do judiciário, em um racismo enquanto realidade fática, constatada pelo Estado, mas não problematizada; esse racismo é definido como "cegueira racial".

As instituições, ao se mostrarem cegas ao conceito de raça e racismo, recusando-se a analisar as hierarquias raciais produzidas por suas práticas e aceitando sem questionamento todas as neutralizações ${ }^{61}$ do debate de raça, deslocando-o para outras categorias como classe, identidade, idade, etc terminam por colaborar e manter a lógica de funcionamento, deliberadamente estruturada e que em nenhum momento teve uma política igualmente deliberada no sentido de desconstruí-las.

${ }^{61} \mathrm{Em}$ países onde a hierarquia social se confunde com a racial, não existe neutralidade em políticas raciais, estas políticas identificadas como "neutras" na verdade têm como base os valores de branquidade, ou seja, os valores raciais do grupo dominantes. 
O pior da cegueira racial ${ }^{62}$ é que os gestores que caracteristicamente trazem esse traço de atuação encaram os que levantam a temática racial como se fossem eles os racistas ${ }^{63}$. Assim, desqualificam os pesquisadores, funcionários e todos que tentem lidar com as implicações raciais das práticas institucionais. (Musumeci, 2005, p.240).

Nos EUA, a sensibilização dos profissionais e a ampliação do âmbito do debate, levando as práticas de filtramento policial à discussão no país por meio dos tribunais, questionando os critérios utilizados para suspeita, trouxe um espaço de discussão sobre o racismo institucional. Steve Martinot (apud Musumeci, 2005, 253) reconceitualiza a discriminação policial ao identificar a discricionariedade não como um espaço livre e neutro para a tomada de decisões profissionais, mas como um reino de impunidade que constitui um regime racial com suas próprias leis e práticas brutais que permaneceram "invisíveis" por deferência da Corte americana.

A criminalização da raça é invertida e passa a ser racialização do crime. O comportamento negro, ilegal ou não, passa a ser considerado criminoso, ao passo que a violência racista branca, processada ou não, torna-se simples comportamento. ${ }^{64}$

Essas variáveis constatadas não são legalmente reconhecidas ou refletidas pelas agências, mas as suas regularidades levam à conclusão de que:

“(..) o predomínio desproporcionado das classes inferiores nas instancias de controlo e nas estatísticas oficiais da criminalidade, não pode imputar-se ao acaso,

${ }^{62}$ Cegueira Racial é a forma como definem os estudiosos o filtramento racial e racismo institucional no sistema de justiça criminal a postura de não problematização no âmbito legal, tecnocrático, de gestão de risco e jurisprudência desta realidade constatada mas ignorada pelos gestores destas políticas. Essa postura de Cegueira Racial pode ser vinculada ao pacto narcísico que a professora Maria Aparecida Silva Bento conceituou em sua tese, onde o silêncio, o não debate e o não reconhecimento da variante racial como relevante faz parte de um acordo silencioso entre os que teme perder os privilégios de que desfrutam numa sociedade onde ser branco é valorado positivamente e implica em vantagens na competição capitalista.

${ }^{63}$ A Comissão Interamericana de Direitos Humanos afirma que essa pratica de minimizar as agressões raciais cotidianas : "tem como efeito a discriminação indireta na medida em que impede o reconhecimento do direito de um cidadão negro de não ser discriminado e o gozo e o exercício do direito desse mesmo cidadão de aceder à justiça para ver reparada a violação. Demais disso, tal prática causa um impacto negativo para a população afro-descendente de maneira geral." (CIDH, 2006)

${ }^{64}$ Apud Musumeci, op. Cit., p, 254) 
antes devem encarar-se como grandezas sistematicamente produzidas".(DIAS \& ANDRADE, 1984, p.385)

A partir disso, surge a demonstração de que a seletividade tem sua constância condicionada às leis de um assim chamado "código social latente", integrado por mecanismos de seleção, no Brasil. Esses mecanismos têm caráter estratificador e buscam perpetuar as desigualdades e criminalizar os assim identificados como fora do padrão normal. Dentre os mecanismos de seleção, podemos destacar como de enorme importância os estereótipos de autores associados às "teorias de todos os dias", isto é, o senso comum sobre o que é criminoso e o que é criminalidade.

Esses estereótipos têm enorme força persuasiva e eficácia seletiva, operando claramente em benefício das pessoas que exibem os estigmas da respeitabilidade dominante e em prejuízo dos que exibem os estigmas da associabilidade e do crime.(DIAS \& ANDRADE, 1984, p.541). ${ }^{65}$

Com a descoberta desse "Código Social Extra-Legal" foi possível encontrar explicação para a regularidade da seleção criminal que superasse a explicação determinista negatória da dignidade humana de determinados grupos das escolas etiológicas, afirmando, assim, que a clientela do sistema penal era constituída de pobres em sua maioria, não porque estes tinham uma maior tendência para delinqüir, mas mais precisamente porque tinham maiores chances de serem etiquetados como delinqüentes.

A professora Vera Regina Pereira Andrade aponta que a eficácia dos mecanismos de seleção manifesta-se não somente na atuação policial, mas também na atividade jurisdicional ao longo da multiplicidade de decisões de que se incumbem os juízes e os tribunais, decisões essas que transcendem os

\footnotetext{
${ }^{65}$ Os estereótipos no momento da formação da convicção do Juiz a partir dos elementos trazidos aos autos operam de forma a beneficiar as pessoas que trazem o estigma de respeitáveis e em desvantagens daqueles que trazem o estigma de criminoso, cor, grupo social, grau de formação educacional, etc. Os Juízes e razão dessas construções esperam um comportamento conforme a lei por parte dos membros dos extratos superiores e contrário a lei dos membros dos extratos inferiores. (ANDRADE, 1994, passim).
} 
elementos legais e oficiais que vinculariam a tomada de decisão. Seja no momento da fixação dos fatos, na sua valoração e qualificação jurídico-criminal ou na escolha e quantificação da pena; seja, assim, na discricionariedade permitida pela vagueza e ambigüidade da linguagem da Lei Penal, seja na discricionariedade para a fixação da verdade processual dos fatos, pela ausência de parâmetros precisos surge postulada como necessária à mediação das normas derivadas do second code ${ }^{66}$ dos juízes.

As decisões judiciais não são sempre dogmaticamente fundamentadas e justificadas, a vagueza e ambigüidade do direito positivo permite um espaço de discricionariedade inerente à Ciência do Direito e a atuação do Juiz, que é dar sentido a lei "criando direito". Assim, a sentença não é algo neutro, mas sim "um silogismo retórico em que se parte da conclusão para depois buscar as premissas" (BRUM, 1980, p.45, apud GROSNER, 2008, p.66)

Essas decisões, assim, são tomadas em função do código ideológico que orientará o operador jurídico a partir das suas expectativas sobre o fenômeno criminal e quem dele é regular cliente (GROSNER, 2008, p.66). ${ }^{67}$ Aos Juízes, membros de estratos economicamente superiores, cabe o recrutamento final, iniciado pelos agente policiais, das pessoas que serão identificadas como criminosos, quase sempre membros dos estratos economicamente inferiores da sociedade.

A seletividade pode ser percebida em função da especificidade da infração e das conotações sociais dos autores, ou seja, ela opera em duas dimensões: a imunidade de certos segmentos sociais face à não atuação do sistema em

\footnotetext{
${ }^{66}$ Second code, código social latente, basic rules, meta-regras, designam a totalidade do complexo de regras e mecanismos reguladores latentes e não oficiais que determinam efetivamente a aplicação da lei penal pelos agentes do controle penal.(Andrade, 2003, p.268), ou regras objetivas do sistema social que, correspondendo às regras que determinam a definição de desvio e de criminalidade no senso comum e seguidas conscientemente ou não pelos aplicadores da lei, estão ligadas a leis, mecanismos e estruturas objetivas da sociedade, baseqadas sobre as relações de poder entre grupos e sobre as relações sociais de produção. (Andrade, 2003, Baratta, 2002 apud GROSNER, 2008, p.59).

67 "Primeiro idealizo a solução mais justa, só depois vou buscar apoio na lei". Com essa frase dita em um programa de televisão, o ministro do STF Dr. Marco Aurélio Melo trás o conteúdo ideológico Realista do Direito, no qual acredita, afirmando que o juiz primeiro decide no seu íntimo e só depois vai buscar os fundamentos de sua decisão na lei.
} 
determinadas situações e contra determinadas pessoas, e a criminalização preferencial, como demonstrada por dados empíricos, sobre determinados grupos.

Tal seletividade ocorre no momento concreto de aplicação da lei penal (criminalização secundária), assim como no momento de escolha, pelo legislador, de determinadas condutas a serem consideradas crimes (criminalização primária) $^{68}$ (ANDRADE, 1994, p. 407). Como exemplo, o professor Nilo Batista levanta o caráter "dupla face" do nosso modelo atual ${ }^{69}$ de controle social no Brasil, onde consumidores têm alternativas à privação de liberdade, como a transação penal e a suspensão condicional do processo. ( 2004, p.113).

Em documentário sobre o judiciário brasileiro, destaca-se a declaração do então secretário de reforma do Judiciário, Sérgio Renault:

\begin{abstract}
"As pessoas são condenadas não é por conta exatamente da forma que os processos, ou o desenrolar da instituição processual se dá, elas são condenadas porque são pobres, são deficientes, são sujas, são feias, enfim. A Justiça, o Poder Judiciário, as coisas funcionam como funcionam porque elas são tocadas por pessoas humanas que tem as suas dificuldades, que têm seus preconceitos, tem suas formas distorcidas de ver a realidade e essa coisa da miséria humana que no Brasil é o que a gente sabe o que é"70."
\end{abstract}

A seletividade, portanto, tanto não é inocentemente atribuída a um caráter fortuito por este representante do Estado, como é atribuída à existência de um "código social" latente, onde o Secretário destaca a importância central presente nos estereótipos de autores e vítimas, associados às "teorias de todos

\footnotetext{
${ }^{68} \mathrm{Um}$ exemplo dessa seletividade realizada primariamente pelo legislador é perceptível no código penal, onde o artigo 176 prescreve que Tomar refeição em restaurante, alojar-se em hotel ou utilizar-se de meio de transporte sem dispor de recursos para efetuar o pagamento (grifo nosso): Pena - detenção, de 15 (quinze) dias a 2 (dois) meses, ou multa.(Notório se torna a proteção do "pendura" onde identificada a disposição de recursos para efetuar o pagamento da refeição por parte dos estudantes de Direito, e a não intenção de o fazê-lo excluído o agente se faz da conduta típica)

${ }^{69}$ O professor Nilo Batista classifica o nosso modelo de sistema penal como sistema penal do capitalismo tardio, ele identifica na história do país três modelos anteriores os quais seriam o colonial-mercantilista, imperial-escravista e o republicano positivista. (BATISTA, 2004, p.105)

${ }^{70}$ Apud SÃO BERNARDO, Op. cit., p. 88.
} 
os dias", isto é, do senso comum da criminalidade, na atuação dos agentes do Estado em todas as instâncias do Controle Criminal.

Essas normas do second code ou código social possuem natureza e impacto reconhecidamente seletivos, uma vez que se apresentam como valores ideológico e morais dos magistrados e, por serem estes selecionados dentre os membros dos grupos sociais privilegiados, acabam por reproduzir como seus second codes os valores e preconceitos de seu grupo social, a elite econômica racial do país (PORTANOVA, 1997, passim),

Quando apontamos os valores desse grupo social, temos que ter claro que esses valores perpassam em sua grande maioria pelo senso comum da elite brasileira. A qual resgata ainda os valores de manutenção e naturalização das desigualdades sociais e raciais do país. Conforme Cristiana Vianna Veras (2000, p.82), é deste extrato de onde saem os profissionais do Direito que assumem cargos na Magistratura, no Ministério Público e, enfim, nos órgãos como agentes estatais com poder de decisão legitimado e manutenção do controle iniciado pela polícia.

A autora deixa claro que o Direito é encarado como um curso que permite a ascensão social, razão que explica o boom das faculdades de direito no país, guardiãs dos portões de acesso às carreiras jurídicas, o que permitiu uma pequena mudança no perfil dos profissionais desta área. Ainda conforme Veras:

\footnotetext{
"Para advogar, é preciso passar no Exame da ordem. Para se tornar um promotor, juiz ou defensor é preciso passar nos concorridos concursos públicos. (....) O simples crescimento do numero de faculdades de direito e, conseqüentemente de estudantes negros, não parece ser suficiente para uma transformação substantiva na mobilidade social do negro, no perfil das profissões jurídicas e no acesso à justiça. Outras medidas são necessárias com vistas a se garantir que o negro ingresse não apenas em uma faculdade de direito, mas, principalmente, que ingresse em boas faculdades de direito. (...) É, pois, necessário que seja assegurado aos diferentes grupos sociais um maior acesso não apenas ao ensino superior de maneira geral, mas às boas faculdades de direito." (2002, pp.75-6).
} 
Como a exemplo do questionário aplicado aos juizes de Franca ${ }^{71}$, quando estes deslocam o problema racial para um discurso que explica as desigualdades apenas por razões sócio-econômicas, ignoram o racismo estrutural afirmando que a maioria dos condenados é negra porque a maioria dos negros é pobre e não tem bons advogados.

A perspectiva de explicação estrutural do racismo reconhece que as manifestações e formas de atuação dos mecanismos racistas podem ser agravadas pela distribuição desigual de riqueza, pela marginalização e pela exclusão social. A declaração de Durban, ao atentar para isso, explicita que os mecanismos de exclusão em razão destes fatores não são idênticos e podem atuar de forma cumulativa ou exclusiva.

O argumento sócio-econômico que os juízes francanos insistiram em reproduzir nada mais é do que um discurso fundado num paradigma, muito enraizado, de explicação das desigualdades raciais no país. Conhecido como paradigma da Escola Paulista, é um modelo também já superado de explicação das relações raciais no Brasil, mas que ainda permanece no senso comum e influencia a concepção de mundo dos profissionais do Direito e, conseqüentemente, as suas decisões, quando é necessário a este apelar para o seu Código extra-legal ${ }^{72}$.

\footnotetext{
${ }^{71} \mathrm{Em} \mathrm{2004}$, como parte do projeto de pesquisa desenvolvido com fomento da Agencia FAPESP foram aplicados questionários e realizadas entrevistas aos/com os juízes das Varas criminais da Comarca de Franca/SP. Nos resultados levantados nessas entrevistas o discurso que desvia a temática racial para um âmbito sócio-econômico, exclusivamente, foi uma constante das respostas dos aplicadores da lei penal e processual penal daquela cidade.
}

72 É coerente acreditarmos que o aumento de estudantes negros implicaria em um processo de reconhecimento do racismo impedindo que este permanecesse um estranho no domínio do Direito, contudo, não podemos "apostar todas nossas fichas" nesta afirmação uma vez que conforme a pesquisa de Veras a inserção em tais cursos denota uma tentativa de embranquecimento por meio da educação, tendo tais alunos um perfil de inibição para discutir tais assuntos "por serem minoria naquele universo, já que tem o privilégio de estar lá, o mínimo que pode fazer e não incomodar levantando questões que não interessam a maioria".( p.98, 2002) 
A indeterminação de conceitos como o de imputabilidade e principalmente do conceito de culpabilidade erigidos pela dogmática em requisitos subjetivos para a responsabilidade penal tem centralizado as atenções das críticas ao sistema uma vez que:

“(...) não se vê como a culpabilidade, da qual não se pode medir objetivamente o grau no processo, possa ser um limite da responsabilidade penal e cumprir uma função de garantia a favor do processado com relação a formas subjetivas, intuitivas e presuntivas de determinação dela." (BARATTA, 1988, pp.61-2)

Huslman (1993) observa de forma complementar que a culpabilidade é uma noção grave e complexa que ninguém domina e com a qual o sistema penal joga perigosamente. Por isto mesmo, "o sistema penal fabrica culpados"(p.67). O nosso sistema de culpabilidade (exigibilidade de conduta diversa) traz a defesa de uma postura moral e conduta homogêneas para os grupos sociais extremamente heterogêneos que compõem a nossa sociedade, deixando explicita a não-vontade de respeitar diferentes valores, por parte dos que elaboram as políticas desse sistema.

A ideologia da reação social desconstruiu o mito do Direito Penal como direito igualitário, ao apontar que:

a) O direito penal não defende a todos, somente os bens a que todos estão interessados e quando castiga as ofensas aos bens faz com intensidade desigual e de modo fragmentado.

b) A lei penal não é igual para todos; o status de criminal é desigualmente distribuído.

c) A lei não constitui a principal variável da reação criminalizadora e de sua intensidade. 
O Sistema Penal apresenta como real função a reprodução material e ideológica das desigualdades sociais, a eficácia de suas funções declaradas é, sobretudo, simbólica ${ }^{73}$ e legitimadora, em vez de instrumental (Castro, 1987, p.84)

Essa discussão sobre a identificação das funções simbólicas do Direito Penal converteu-se no ponto central de discussão sobre os sistemas penais e de política criminal dos dias atuais. É claro que esta crise de deslegitimidade demandou uma corrente relegitimadora, que representa a continuidade do discurso criminológico positivista. MASSUNARI (2002, p. 15) afirma que o crescimento dessas orientações criminais é hoje uma real tendência mundial.

O expansionismo, independentemente das suas várias formas teóricas assumíveis, defende o aumento da intervenção penal, seja ampliando o rol de bens jurídicos, seja agravando as leis ou intensificando a repressão policial, entendendo o Direito Penal como único ou principal meio de solução dos conflitos sociais. O assim identificado Direito Penal do inimigo retoma os valores positivos em uma sociedade globalizada, do risco, na qual a insegurança torna aparentemente razoável o argumento de que em determinadas situações as garantias fundamentais protetoras da dignidade de suspeitos podem ser ignoradas nas práticas do Estado, uma vez que este não é pessoa, mas coisa que ameaça a segurança.

ZAFFARONI (2007, p.20) afirma que esse tipo de tratamento não despersonaliza somente a pessoa que é tratada desta maneira, mas também termina por despersonalizar toda a sociedade onde tais práticas são admitidas. Esse discurso expansionista de proteção social está presente, no Brasil $^{74}$, em

\footnotetext{
${ }^{73}$ Ao afirmar que o direito penal é simbólico a professora Vera Regina Pereira Andrade explica que não significa afirmar que ele não produz efeitos e que não cumpra funções reais, mas sim, afirmar que as funções latentes predominam sobre as declaradas.

${ }^{74}$ Não podemos esquecer que o nosso país encontra-se em um processo de transição, onde os
valores autoritários de um estado militar convivem com a intenção de direcionamento a um Estado
Democrático de Direito, conforme anseiam as previsões de nossa CF/88. A doutrina de segurança
nacional apontada como análoga à doutrina de Lei e Ordem, uma vez que ambas são
alimentadas por Estados autoritários, a exemplo do Brasil no período da ditadura, ainda faz parte
dos valores do senso comum. Como exemplo podemos apontar os ainda presentes suspiros de
} 
programas de $\mathrm{TV}^{75}$ que demandam punições mais severas aos "criminosos", maior intervenção estatal no sentido de oferecer maiores garantias de segurança, além de alardearem, a todo momento, o aumento da criminalidade, "denunciando" o estágio intolerável em que esta se encontra.

As capas de revistas de circulação nacional, desde o fim dos anos $70^{76}$ reproduzem esse mesmo discurso, oriundo da Belle Époque, quando nas grandes metrópoles européias o medo das elites face aos perigos resultantes de novas formas de vida no meio urbano traduziu-se em uma preocupação com o crime e a criminalidade associados à pobreza e às condições de vida do proletariado assalariado.

Sabendo que a suspeita não passa do medo fardado, e de que o medo no Brasil desenhou o jovem, pobre, negro como ameaça potencial para a sociedade, resultando numa perversa realidade onde os que possuem esse perfil constituem a maioria dos encarcerados filtrados pelo sistema, que não consegue ser fiel à real distribuição de crimes na sociedade, a miopia histórica nos impede de perceber que os números divulgados pela Organização das Nações Unidas (ONU) em seu relatório "Estudo das Nações Unidas sobre a Violência contra Crianças" ${ }^{\prime 77}$ são o legado de uma tradição histórica que não foi alterada e ainda permanece em vigor nas instituições de controle social.

saudades do governo militar, quando a criminalidade não era tão intensa, por parte da população do país.

${ }^{75} \mathrm{O}$ papel da mídia, decisivo para a formação da opinião pública é fundamental no que tange à difusão da ideologia dos movimentos de lei e ordem, desvirtuando a apreensão da realidade e fazendo a população, principalmente a classe trabalhadora, acreditar que a criminalidade é um fenômeno assolador gerando uma sensação de intranqüilidade e pânico. Dessas idéias origina-se a ideologia que o único meio de combate à criminalidade "violenta", dentro da lógica positivista da pena como retribuição e castigo, são as penas mais severas.

${ }^{76}$ Colocamos como marco temporal para esta afirmação o fim dos anos 70 por termos encontrado, em um sebo da cidade de São Paulo, uma revista, datada do ano de 1979, que tinha como reportagem de capa os alarmantes índices de criminalidade que teriam alcançado o auge de sua expansão.

${ }^{77}$ Em cada grupo de dez jovens de 15 a 18 anos assassinados no Brasil, sete são negros. Concluiu o especialista independente das Nações Unidas, Paulo Sérgio Pinheiro, em seu estudo Global Sobre a Violência Contra as Crianças, apresentado à Assembléia Geral das Nações Unidas em 11 outubro de 2006. 
Os movimentos expansionistas procuram, na direção contrária das escolas criticas, não questionar o sistema penal, mas sim legitimá-lo indiscutivelmente ${ }^{78}$, cumulando com demandas de recrudescimento das penas, ampliação dos tipos penais e redução das garantias processuais. Seduzem a população de forma que esta não discuta a funcionalidade e efetividade do sistema, apenas o legitime quando da demanda de penas mais "duras" e "eficientes" para os "criminosos", a fim de reduzir a criminalidade ${ }^{79}$ que é sempre "a maior de todos os tempos e sem controle".

Essa cultura do medo implica a legitimação de uma polícia violenta ${ }^{80}$ que ao atuar desta forma livre para negociar vida ou morte tem sua busca por fortalecimento transformada em porta para a corrupção, enfraquecimento e descrédito. (MUSUMECI, 2005, p. 13).

Interessante notar que esta cultura do medo, que atinge a população e os profissionais de segurança, também acaba por obrigar a população a buscar uma segurança prometida pelo sistema penal, promessa esta que não se cumpre. Contudo, esta frustração nunca é explicada; inconscientemente o senso comum sabe da ineficiência do sistema, mas é levado a acreditar que, sem este, a

\footnotetext{
${ }^{78}$ Zaffaroni afirma que reconhecida a seletividade do sistema de controle penal, coube à doutrina legitimadora da ordem respondê-la de forma que essa seletividade tivesse uma função. A funcionalidade de "prevenção geral positiva" constituir-se-ia disso, do reconhecimento da seletividade e da justificativa de manutenção do sistema seletivo como o é. Zaffaroni diz que essa função simbólica da pena, justificativa da seletividade do sistema, não é inovadora e tem em Jean Bodin (um dos fundadores do conceito de soberania) o seu expositor mais claro. (Zaffaroni, 2006, p.88/89)

${ }^{79} \mathrm{Em}$ relação aos conceitos de crime e criminalidade este movimento retrocede adotando uma compreensão positivista de que esta consiste na expressão do lado patológico da sociedade, e esta é uma enfermidade causada por um ser daninho, partindo assim as premissas deste movimento para uma lógica reacionária simplificando o problema da criminalidade e apresentando o Direito penal como uma formula mágica capaz de solucionar todos os conflitos inclusive os de raízes sociais.

${ }^{80}$ O equívoco da posição de quem afinal termina aceitando uma polícia mais violenta está em que boa parte da impunidade, cuja cura se deseja, tem sido o resultado não da aplicação da lei, mas da incapacidade do Estado de aplicá-la. Para ser bem resumido: a sociedade brasileira, nos seus 176 anos de história institucional independente, tem sido incapaz de fazer aquilo que o Estado liberal mínimo prometeu, ou seja, aplicar universalmente a lei. Para esta incapacidade, o discurso contrário à defesa dos direitos humanos propõe indiretamente a abolição da lei. Ou melhor, propõe que alguns devem estar acima da lei, para poder disciplinar a sociedade. (LOPES, 2000, p.80)
} 
barbárie irá se instalar e, por tal motivo, não deve questioná-lo, e sim arcar com o "custo segurança" 81 .

${ }^{81}$ Custo segurança seria o preço que a sociedade aceita pagar em troca da segurança, a exemplo do contrato social de Hobbes em que abrimos mão de algumas liberdades individuais em troca da proteção do Estado, quando "pagamos" o custo segurança aceitamos o preço da ineficiência do sistema acreditando que em troca este funcionará, impedindo um possível estado de barbárie constantemente profetizado. 


\section{Capítulo 4}

\section{Direitos Humanos Acríticos e Racismo Estrutural no Brasil os dados sobre o programa de Penas Alternativas no Estado de São Paulo.}

"Costuma-se dizer que ninguém conhece verdadeiramente uma nação até que tenha estado dentro de suas prisões. Uma nação não deve ser julgada pelo modo como trata seus cidadãos mais elevados, mas sim pelo modo como trata seus cidadãos mais baixos" NELSON MANDELA - Long Walk to Freedon, Little Brown, Lodres: 1994.

A Estrutura historicamente construída do Sistema de Controle Social Brasileiro e as limitações da tradicional concepção liberal sobre o que vem a ser e quais são as funções dos Direitos Humanos e suas aplicações terminam por resultar nos números que constatamos nos programas onde ocorreram intervenções universalistas, como o Sistema de Saúde, o de Educação, bem como o Sistema Criminal.

O Sistema Criminal no Brasil foi tradicionalmente constituído de forma racializada e percebemos que, a exemplo do Sistema Educacional, não poderia refletir de forma diferente os desiguais impactos que as políticas publicas no País apresentam, em função do racismo estrutural.

Escolhemos a Instituição Criminal para realizar uma analise das limitações que as políticas Universalistas de Direitos Humanos encontram em sua aplicação no Brasil, principalmente em função da prática constante, ora constatada de 
tornar invisível do elemento racial, constituinte da formação do País e, mais intensamente, dessa Instituição. Como em outros programas e projetos brasileiros nos órgãos de persecução penal. o racismo, apesar de ser constituinte, permanece um tabu interno que precisa ser desconstruído.

A Instituição Criminal, conforme diz Mandela, é onde podemos perceber como os Direitos Humanos são concebidos: como direitos de todos os seres humanos, sem distinção, ou como direitos dos que fazem jus a eles, sendo que esta última concepção indica que nem todos os seres humanos são portadores de dignidade.

Acreditamos que essa índole de distinção, de Direitos Humanos para Humanos Direitos, naturaliza as práticas atentatórias à Dignidade Humana dentro das diversas instituições estatais, e não só no Sistema de Controle Criminal, a exemplo dos números levantados sobre o sistema da saúde no Rio de Janeiro; determinadas práticas colocam em questão a legitimidade do próprio Estado que se propõe ser democrático e de direito.

Certos aspectos das nossas instituições que colocam em duvida o Estado Democrático de Direito, não foi desconstituído de forma nem mesmo tênue no Sistema Criminal nacional, por ser, ainda, uma instituição que nega a dignidade de determinados grupos de formas diversas durante todos os procedimentos que aplica. Mesmo em face das garantias processuais constitucionais, como o Devido Processo Legal, a Ampla Defesa e o Estado de Inocência.

Tendo essa estrutura histórica que já apresentamos como base é que podemos entender porque razão a aplicação das recomendações da ONU, em tese espaço em que igual dignidade humana seria aplicada de forma plena, por ser o valor informante absoluto, não é plenamente eficaz.

Esses resultados díspares deixam claro que os resquícios autoritários e desiguais das instituições de controle social permanecem, inviabilizando a plenitude dos valores que informam o Estado Democrático de Direito ao ignorar o elemento constituinte nacional que é a amplitude e diversidade de grupos étnicos raciais.

4.1 Teoria Crítica dos Direitos Humanos. 
Assim como todo o direito, as normas de Direitos Humanos não distinguem-se das outras e apresentam-se como um produto cultural, nesse sentido Wolkmer diz que :

"Por certo, o Direito materializado na lei não expressa o verdadeiro significado da justiça, tampouco representa a vontade geral do povo ou a manifestação pública do legislador, mas os interesses das camadas economicamente dominantes. Daí seu caráter de Instrumentalização repressiva que legitima a manutenção das distorções econômicas e das injustiças sociais". (Wolkmer , 2004, .09)

O conceito de dignidade da pessoa humana que informa as bases da teoria sobre Direitos Humanos, bem como as bases das teorias sobre o Estado Democrático de Direito, é um produto da cultura. Este conceito tem passado por inúmeras transformações durante a história moderna, tendo se apresentado, inicialmente, apenas como garantia da liberdade do proprietário, chegando hoje a valores como o de garantia de vida com qualidade, bem estar social e direito à formação positiva de uma identidade para todos os membros da espécie humana sem distinção.

É em razão desses traços característicos e constituintes dos Direitos Humanos, de conceitos historicamente construídos, que podemos apontar a não casualidade das normas jurídicas de direitos fundamentais. Estas não surgem para regular o abstrato em razão de vontades abstratas, elas, pois normas surgem em razão do conflito de interesses num determinado tempo e contexto espacial e social, como ficou caracterizado no capitulo anterior "não legisla-se sobre o abstrato ou intangível".

Os direitos humanos, considerados em sua dimensão de norma jurídica, não apenas representam o resultado de lutas emancipatórias históricas, mas, ao mesmo tempo, podem ser utilizados como instrumentos de legitimação de uma determinada ordem social e política tornando-se parte não apenas de uma cultura, mas também de uma ideologia política hegemônica. (Herrera, 2000, p.15).

Ainda continuando nesse debate, o professor Joaquim Herrera afirma que: 
"Los derechos humanos, como, por lo general, todo fenómeno jurídico y político, están penetrados por intereses ideológicos y no pueden ser entendidos al margen de su trasfondo cultural y contextual." (2000, p.23)

É dentro desta linha de concepção de que os direitos não são inocentemente declarados, devido aos interesses e a racionalidade que os precedem, que entendemos como importante a produção de concepções e práticas que, se relacionem a todos os aspectos da sociedade que influenciam a construção e aplicação das normas, sejam elas de direitos humanos ou não.

\begin{abstract}
"A lei não nasce da natureza, junto das fontes freqüentadas pelos primeiros pastores; a lei nasce das batalhas reais, das vitórias dos massacres, das conquistas que têm sua data e seu heróis de horror; a lei nasce das cidades incendiadas, das terras devastadas, ela nasce com os famosos inocentes que agonizam no dia que esta amanhecendo." (Foucault, 2005, p.58/59).
\end{abstract}

Somente tendo por relevante esses elementos é que os contextos regulados por essas normas poderão ser, realmente, transformados. Apenas ao observar com atenção os elementos constituintes, sociais, econômicos, políticos e territoriais, em que e para que se dão essas relações, dos contextos os quais condicionam a satisfação das necessidades humanas, poderemos produzir conhecimentos que tornarão, efetivamente, de acesso mais igualitário o desfrute dos bens sociais.

"Los derechos humanos, más que derechos "propiamente dichos" son procesos; es decir, el resultado, siempre provisional, de las luchas que los seres humanos ponen en práctica para poder acceder a los bienes necesarios para la vida. Por tanto, nosotros no comenzamos por "los derechos", sino por los "bienes" exigibles para vivir: expresión, confesión religiosa, educación, vivienda, trabajo, medio ambiente, patrimonio histórico-artístico." (Herrera, 2008, p.106).

Nesse mesmo sentido o professor Wolkmer ao analisar a obra de Marx "A Questão Judaica", afirma : 
"a idéia dos direitos humanos não é algo inato ao ser humano, tampouco [...] uma dádiva da natureza, um presente da história, mas fruto da luta contra o acaso do nascimento, contra os privilégios que a história, até então, vinha transmitindo hereditariamente de geração em geração. [...] só pode possuí-los aquele que os soube adquirir e merecê-los." (Wolkmer, 2004, p.13)

Joaquim Herrera critica a análise de conteúdos que ignoram o contexto e as circunstâncias que condicionam os ideais. Para esse filósofo, analisar um direito humano ou uma política de direitos humanos exige que tenhamos em conta as posições e os vínculos que se dão em um determinado espaço real e concreto (p.33, 2000).

“ Los derechos humanos, como cualquier objeto de investigación social vienen determinados y determinan el conjunto de ideas, instituciones, fuerzas productivas y relaciones socieles de producción que predominan em um moemento histórico, em um contexto espacio-temporal concreto y que son justificadas o criticadas por um conjunto de discursos y narraciones que cosntituyen el universo simbólico de legitimación "(Herrera Flores, 2000, p.41).

É em razão desta concepção, de que as normas não resultam da vontade de um legislador que mora nas nuvens, que os resultados do sistema jurídico, da aplicação das normas de Direitos ou de Direitos Humanos, bem como de sua elaboração, não podem ser analisados à parte do contexto em que são constituídos. Entendemos as normas como elementos que estabelecem uma forma precisa a partir da qual se satisfará ou se constituirá obstáculos à satisfação do acesso aos bens necessários a vida digna (Herrera, 2008,p.29).

"Como puede verse las cosas no son tan fáciles. No podemos quedarnos tranqüilos creyendo que con la existencia de una norma ya tenemos el acceso a los bienes, (incluso si nos referimos a la situación de los derechos en los países desarrollados económica y jurídicamente). Puede que la norma no pueda aplicarse por falta de medios económicos. Puede que no se quiera aplicar por falta de voluntad política. O, quizá se dé el caso de que una persona o de un grupo partan de coordenadas culturales que impidan su puesta em práctica. ¿Qué hacer con un instrumento que "tenemos" si no podemos ponerlo a funcionar por falta de medios, por falta de políticas públicas o por razones que apelan a alguna tradición considerada inamovible?" ( Herrera, 2008, 110) 
Maka Mutua, ao discutir sobre os fins de uma teoria aplicada de Direitos Humanos, pontua que um movimento realmente legitimado de Direitos Humanos dificilmente será encampado pelas elites ou pelo Estado, como a história comprova. Um movimento de Direitos Humanos será sempre instrumento de batalha nas mãos dos menos privilegiados. Esse professor observa que isso somente será possível quando o movimento tiver extirpado de si o Eurocentrismo, racismo e preconceitos. (Mutua, 2007, p.05).

Por ser um produto da cultura, o conceito de Direitos Humanos sempre perseguiu e ainda persegue um objetivo: a proteção da dignidade. Esses direitos são em seu tempo, quase sempre contra hegemônico, seja essa proteção garantida pela efetivação dos Direitos Políticos, ou pela efetivação dos Direitos Econômicos Sociais e Culturais.

Hoje professores como Joaquim Herrerra, Boaventura de Souza Santos e Makau Mutua entre outros encampam uma nova e necessária percepção sobre a teoria, a prática, as funções e os objetivos dos direitos humanos. Esse debate, ao nosso ver, é desenvolvido de uma forma mais complexa do que debates filosóficos anteriores, que legitimaram a teoria dos direitos humanos durante vários anos, levaram a campo.

A partir desses teóricos podemos perceber que o recebimento acrítico de valores universais e universalizantes de direitos humanos, construídos em realidades distintas das dos países periféricos, onde as sociedades estruturalmente desiguais foram constituídas e permanecem reproduzindo como forma de existência a miséria atentatória a dignidade humana, implica em uma, quase, ineficiência desses valores/normas quando não os transforma em instrumento para manutenção da lógica posta historicamente.

As alterações institucionais fora dos valores pautados nos DESCS, e em alguns casos até dentro desses valores resultaram e resultam ainda hoje, no Brasil, na falta de mudança na estrutura da sociedade, porque essas leis são aplicadas de forma a manter os privilégios, como a desigualdade racial refletida no "privilégio branco".

As estruturas e as instituições que formam essa dinâmica de inamovibilidade são elementos de uma determinada sociedade em um dado momento informada por valores que tornam exigíveis a percepção do contexto em que determinadas teorias são aplicadas. Essa exigência não se resume apenas a 
importar e transpor essas idéias. É por essa razão que tais intervenções demandam a percepção dos atores envolvidos nos conflitos, do contexto e dos valores no espaço onde são efetuadas as intervenções pautadas em teorias não locais.

Trazer pedagógica e praticamente a historicidade dos direitos humanos supõe afirmar que a concepção dominante da atualidade e seus resultados não caíram de nenhum céu estrelado e não resultam do acaso.

Certamente que essa crítica é passível de ser encontrada na obra $A$ Questão Judaica, mas:

"para além de uma crítica aos direitos humanos de natureza formal e liberal-individualista, cumpre destacar o significado de suas assertivas, não só no sentido de demarcar as representações jurídicas como instâncias negativas de alienação, mas, sobretudo, como possibilidade prática de um Direito social que contribua para superar as limitações da emancipação política no sentido de alcançar a emancipação humana efetiva". (Wolkmer, 2004, p.05).

Como tudo, essa concepção do que vem a ser Direitos Humanos tem uma origem concreta em alguma forma de luta social pela dignidade humana. Essa afirmação parece irrelevante e lugar comum não fosse o fato de a ideologia hegemônica sempre tentar ocultar as origens e causas dos fenômenos. (Herrera, 2000, p.59) ,Herrera continua ao dizer que conhecer as origens históricas nos ilumina sobre as razões, porque temos este estado de coisas e não outro. (2000, p.60).

A Teoria de Direitos Humanos tem abarcado tanto a temática do encarceramento e da criminalidade quanto a temática da desigualdade como elementos históricos e atuais de exclusão e distanciadores do direito dos seres humanos assim considerados dignos do desfrute de uma dimensão humana completa.

Entendendo a teoria de Direitos Humanos e sua aplicação como, necessariamente, um movimento contra hegemônico e difícil de ser encampado pelas elites é que o entendemos como instrumento legítimo para combate ao racismo, se aplicado conforme a construção moderna, que percebe a possibilidade dos valores centrais serem desvirtuados durante a aplicação das teorias. 
$E$, ainda em razão do reconhecimento da necessidade de se encarar a temática do racismo como um elemento transversal às inúmeras formas de violação aos Direitos Humanos, entendemos pautados nas concepções apresentadas pela teoria crítica dos Direitos Humanos, que a aplicação alienada de uma política enraizada em valores de dignidade da pessoa humana ainda assim pode terminar por manter a até mesmo legitimar estruturas postas em determinadas sociedades, que violam os valores Humanos e deslegitima o Estado de Direito a exemplo da questão criminal e racial no Brasil.

A estrutura Social brasileira, assim como outras estruturas sociais no mundo, promove desigualdade racial na distribuição de bens sociais, sejam esses bens políticos ou econômico-sociais, mesmo na ausência de atitudes notoriamente racistas e mesmo na falta do que se chamaria de comportamento de auto sabotagem das minorias raciais. ${ }^{82}$

É por essa razão que toda a prática que busque desconstruir as diferenças duráveis no acesso a esses bens devem considerar as dinâmicas e a abordagem crítica dos Direitos Humanos que se compromete com isso: a percepção ampla dos elementos sociais que negam sistematicamente direitos a determinados grupos e inviabilizam a eficácia da aplicação de uma teoria de Direitos Humanos.

A temática do racismo, ignorada e invisibilizada no Brasil, até como estratégia de sobrevivência das práticas e condutas referentes a esse padrão de comportamento, o qual nega direitos fundamentais, apresenta-se como elemento transversal e, por essa razão, surge em quase todos os temas de direitos humanos como saúde, educação, entre outros. E, na temática sobre as prisões e o direito a tratamento digno dos encarcerados não é diferente, surgindo a questão do racismo em documentos internacionais e em diplomas legais nacionais a exemplo da recomendação da ONU que segue:

"Recomendação Geral n. XIII (1993), a qual determina que, em atenção ao artigo 7 da Convenção, os Estados partes devem promover programas de capacitação e de formação de agentes públicos, com especial atenção àqueles que tem poder

\footnotetext{
${ }^{82}$ Maria Krysan (2008, passim) ao trazer o conceito de "blind spots" em seu artigo sobre racismo estrutural e moradia, coloca em dúvida o que seria a auto sabotagem ou o comportamento de auto-exclusão. A autora ao analisar as opções de moradia entre brancos e negros, pontua que essas preferências não são neutras e ao contrário de ser uma promoção de auto segregação em determinados momentos pode representar um mecanismo de proteção, à exemplo do que alguns chamam no Brasil de mecanismo de auto-sabotagem dos Afro-Descendentes.
} 
de detenção e de prisão, como os policiais militares, os promotores de justiça, os juízes etc, Pretendendo, assim, garantis que todas as autoridades e instituições públicas, nacionais e locais, não praticarão atas de discriminação racial, mas garantirão a observância dos direitos previstos no art 5 da Convenção. Para tanto, essa capacitação deve abarcar a disseminação de conhecimentos na área de direitos humanos, enfocando prioritariamente as obrigações contraídas pelo Estado com a ratificação dos documentos internacionais de proteção a esses direitos. Tal treinamento deve assegurar que, no cumprimento de seus deveres legais, os funcionários públicos respeitem e garantam a proteção da integridade e da dignidade humanas, além dos demais direitos, sem distinção de raça, cor, nacionalidade ou origem étnica. Informações sobre esse programa de capacitação e treinamento devem consta dos relatórios periódicos a serem encaminhados ao Comitê". (Piovesan , 2008, p.38)

É nesse contexto de revisão crítica da teoria de Direitos Humanos e sua aplicação que o processo penal brasileiro não pode ser examinado como uma experiência de laboratório, distante da realidade para a qual foi projetado quando buscamos informá-lo com valores de Direitos Humanos. Em que medida determinadas mudanças, a exemplo do programa de penas alternativas, são operáveis eficientemente ignorando especificidades culturais e sociais do nosso pais?

\subsection{Panorama do Sistema Carcerário do Estado de São Paulo.}

No capítulo anterior acreditamos que conseguimos delinear como o nosso sistema de controle social foi construído sobre bases autoritárias e racistas, principalmente o sistema penal brasileiro, que viu o encarceramento, o cerceamento do direito de liberdade dos ofensores dos bens socialmente relevantes, alguns bens mais socialmente relevantes para aqueles detentores do poder de seleção dos bens e condutas, como única resposta compatível as condutas de violação desses.

Importante pontuar que nossa construção de controle social e político criminalmente sempre foi criticada uma vez que o excessivo número de bens jurídicos tutelados, a percepção do sistema penal como resposta para problemas sociais e a incoerência entre as demandas de um grupo da sociedade e a lógica 
organizacional do sistema sempre foram elementos que terminavam por deslegitimá-lo.

È por essa razão que acreditamos que as estatísticas criminais passam a assumir nos países periféricos apenas a função de proporcionar o conhecimento de um setor da criminalização, a criminalidade legal ${ }^{83}$, como identifica Aniyar de Castro (1983, p.67) trazendo uma nova dimensão de analise científica das estatísticas oficiais.

Essas estatísticas, para o paradigma da reação social, funcionam como um instrumento privilegiado para estudo não da criminalidade, mas, sim, da lógica do controle social, isto é, do modelo de comportamento das instâncias de controle e das suas específicas "clientelas" uma vez que :

"nem todo delito cometido é perseguido, nem todo delito perseguido é registrado, nem todo delito registrado é averiguado pela polícia, nem todo delito averiguado é denunciado, nem toda denuncia é recebida e nem toda denuncia termina em condenação."(BARATTA, 1991, p.103).

Encarada como desacreditada, pelos recentes estudos de criminologia, a idéia de que o crime é a exceção dos padrões de comportamento humano, e considerando que hoje as condutas tipificadas são encaradas como o padrão de comportamento da maioria dos cidadãos identificados como "normais" podemos alcançar determinadas conclusões sobre o sistema de controle ao analisar o perfil dos alcançados pelo processo de seleção primária, secundária ou terciária do sistema penal.

Essa construção distinta de criminalidade que identificou o criminoso como membro de camadas sociais antes não atingidas pelas penas e encarceramento requer uma nova configuração do controle social no Brasil.

É apenas assim que conseguimos explicar o crescente aumento no número de condenados às penas de prisão no Estado de São Paulo, a maior percepção

\footnotetext{
${ }^{83}$ Aniyar de Castro identifica três tipos de crimialidade que seria a legal: registrada em estatísticas oficiais, a criminalidade aparente: conhecida pelos órgãos de controle social mas não constam das estatísticas e por fim a criminalidade real, ou seja, a totalidade dos delitos cometidos na sociedade.
} 
do "crime do colarinho branco como conduta criminosa, e a conseqüente necessidade de aplicação de alternativas à pena de prisão. O Estado, no seu limite, não consegue perseguir todas as condutas que tipificou, e se conseguisse geraria um colapso no sistema social, direção para qual estávamos quase seguindo.

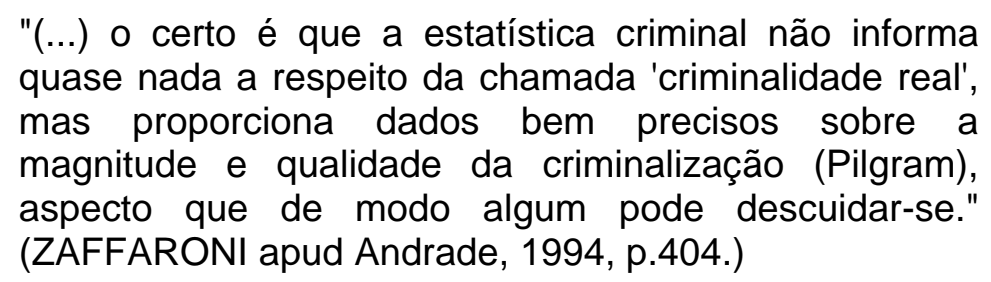

Acreditamos, concordando com Zaffaroni, poder usar dados oficiais para entender e perceber a lógica de funcionamento do Sistema de Justiça como um todo e por que não do Sistema de Justiça Criminal, quando aplica suas políticas de Direitos Humanos?

Nesse contexto de compreensão sobre o perfil de quem é selecionado pelo sistema de controle social, das limitações dos dados estatísticos oficiais e da utilidade destes para compreensão de parte da lógica do sistema, partimos para as análises dos dados oficiais, referentes ao Estado de São Paulo.

O Departamento Penitenciário Nacional divulgou que o sistema carcerário paulista opera 50\% acima de sua capacidade, mesmo contando com o maior número de unidades carcerárias do país, 147 unidades carcerárias ao todo.

No Estado de São Paulo temos, segundo relatório da Comissão de Direitos Humanos e Minorias da Câmara dos Deputados publicado em Brasília em Julho de 2006, o seguinte quadro:

- $\mathrm{N}^{0}$ de vagas existentes

- $\mathrm{N}^{\circ}$ efetivo de presos.

125.804

- $\mathrm{N}^{0}$ de Unidades prisionais. 144 
No início de 2007, a Secretaria de Administração Penitenciária já contabilizava 145 mil detentos na sua contagem da população prisional e ao final do mesmo ano o número de presos era de 149.310. Podemos, assim, perceber que em um ano a quantia de encarcerados no Estado de São Paulo aumentou em mais ou menos 4 mil detentos.

Evolução do número de presos nos EUA e Brasil (1980-2007)

\begin{tabular}{|c|c|c|c|}
\hline Ano & EUA & Ano & Brasil \\
\hline 1981 & 369.000 & 1985 & 39.609 \\
\hline 1991 & 824.000 & 1990 & 90.000 \\
\hline 2007 & 2.319 .000 & 2007 & 422.509 \\
\hline
\end{tabular}

Fonte: Wacquant, Loïc. Punir os pobres. Nalayne Pinto (dados do Ministério da Justiça)

Em face desse contexto de demanda reprimida, em que podemos perceber o sistema de controle não alcançando a todos, e mesmo obtendo esse êxito em um ínfimo número das condutas típicas não consegue prestar de forma devida e eficiente, em face da demanda reprimida, das vagas e das condições de aplicação das penas de restrição de liberdade. Por isso surgiu, como resposta a esse colapso penitenciário o programa de penas alternativas.

4.3 O Programa de Penas Alternativas e suas incongruências Raciais.

Apresentando-se como uma aparente resposta ao inchaço do sistema prisional nacional, em um contexto em que a criminalidade de colarinho branco no Brasil também estava sendo perseguida e condenada pelas instâncias judiciais de controle social e o perfil da criminalidade muda, não sendo identificado como autor de condutas típicas somente aqueles que faziam parte do estereotipo de pobre e negro, mas sendo percebido que a mínima qualificação do sistema implicava no alcance de uma classe antes isenta do controle social repressivo, é que podemos perceber uma ampliação da política de Medidas Alternativas à Pena de Prisão. 
Apesar dos debates, que legitimam a necessidade de repensarmos o nosso controle social, o elemento constituinte da forma como o concebemos inicialmente, o racial, fator que deveria apresentar-se transversalmente em todos os debates sobre políticas públicas nacionais, passa desapercebido também nessa instituição o que termina por apresentar a nós um efeito placebo da política de Medidas Alternativas à Pena de Prisão em face da proposta declarada de mudança na concepção sobre reeducação e ressocialização.

As penas alternativas, enquanto recomendação internacional de política criminal, não são um dado recente. Historicamente podemos remontar ao conteúdo da Declaração Universal de Direitos Humanos de 1948 que em seu art V previa "ninguém será submetido à tortura, nem a tratamentos ou punições cruéis, desumanos ou degradantes", no entanto, somente em 1955 com a edição das Regras Mínimas para tratamento dos presos é que temos a recomendação da redução e não aplicação de penas restritivas de liberdade. O pacto Internacional dos Direitos Políticos e Civis também faz referência à necessidade de execução e fiscalização de alternativas à pena de prisão.

O professor Luiz Flávio Gomes pontua que na atualidade a pena de prisão, por si só, para além do seu fracasso, constitui a síntese mais emblemática das punições torturantes desumanas degradantes e cruéis. (1997, p.04) tendo em vista a estrutura do nosso sistema carcerário. .

A ampliação dessas políticas criminais dá-se com a maior difusão da segunda dimensão descontrutora e deslegitimadora do sistema penal e seus paradigmas. O paradigma crítico que, como anteriormente pontuamos, produziu resultados em duas dimensões: a dimensão propriamente desconstrutora, consubstanciada pela crítica historiográfica, sociológica e criminológica do moderno sistema penal, já apresentada no capitulo anterior, e a dimensão das políticas criminais alternativas e dos movimentos de reforma, que a ela se seguiram e somente puderam ser pensadas a partir desta desconstrução apresentada no capitulo anterior.

Apesar dessas referências em documentos e declarações de Direitos Humanos Internacionais à importância da redução e até mesmo eliminação das 
penas restritivas de liberdade, penas as quais negam um direito fundamental do indivíduo, necessariamente atingido quando da sua execução, somente foi pautada na Assembléia Geral da ONU de 1990.

A princípio os debates foram direcionados no sentido da necessidade de se humanizar a pena de restrição de liberdade e após a percepção das imensas dificuldades e obstáculos que essa demanda encontra foi votada a aprovação das Regras Mínimas sobre as Medidas não privativas de liberdade das Nações Unidas para prevenção do Delito e Tratamento do Delinqüente. Essa declaração de 1990 ficou conhecida como "As Regras de Tóquio".

As Nações Unidas intimaram os Estados Membros a efetivarem as previsões normativas dessas regras, afirmando que os que não se comprometesse com tal efetivação seria considerado Estado desertor dos Direitos Humanos.

No Brasil, o Código de 1984 trouxe a possibilidade de aplicação de penas restritivas de Direito, mas apenas em 1995 com a promulgação de lei 9.099, que criou os Juizados Especiais Criminais, é que os procedimentos referentes aos crimes de menor potencial ofensivo, apenáveis com medidas alternativas à prisão, passaram a ser estabelecidos e conceituados.

Em determinados países do continente Europeu 80\% dos condenados por alguma conduta típica cumprem penas alternativas. No Brasil segundo o Depen desde quando o sistema público de monitoramento de PMA foi implementado, em 1987, o número de pessoas que cumprem penas alternativas é maior do que o número de presos no Brasil. Em Junho de 2008 quando esses dados foram divulgados pelo Infopen (Sistema de Estatísticas do DEPEN) o número de pessoas que cumpriam penas alternativas era de quase $500^{84}$ mil em todo o país.

No Estado de São Paulo, unidade da federação em que optamos reduzir a nossa análise, desde o início de sua aplicação o programa de Medidas

${ }^{84}$ Segundo o Infopen, no primeiro semestre do ano de 2008 o número de encarcerados era de 439.737 e o número de pessoas que cumprem medidas alternativas a pena de prisão era de 498.729. Se o país tivesse mais de 800 mil pessoas encarcerados estaríamos com um colapso maior do que já temos do sistema prisional. 
Alternativas à Pena de Reclusão, que começou em 1997, recebeu 44.156 pessoas.

Os inequívocos propósitos da aplicação dessas medidas alternativas pautam-se na necessidade de redução do número de encarcerados, reduzindo assim as superlotações de presídios.

É explicita a busca, quando da opção pela aplicação dessas Medidas alternativas, de favorecer a ressocialização do autor do fato típico evitando, assim, o contato "pernicioso" deste indivíduo com o cárcere bem como a estigmatização que é um dos resultados não considerados na aplicação da pena e termina por tornar a condenação e reclusão uma pena socialmente "ad eternum".

São essas justificativas e vantagens da aplicação das penas alternativas e medidas alternativas à pena de prisão as quais não são igualmente disponibilizadas, enquanto bem sócial, à todos os membros do Estado de São Paulo de forma igualmente devida. É em face dessa negação desses bens, os quais são tutelados quando da opção do Juiz em aplicar uma medida alternativa à pena de prisão, que podemos perceber uma lógica estrutural influenciando no devido funcionamento do sistema criminal e da política de Direitos Humanos neste espaço.

A secretaria de Administração Penitenciaria do Estado divulgou em dados de pesquisa recente que o prestador de pena alternativa em São Paulo é branco, solteiro, trabalhador autônomo, tem entre 21 e 30 anos, não completou o ensino fundamental, ganha de 1 a 3 salários mínimos, nunca cumpriu pena anteriormente e não usa drogas.

Eles podem tanto terem sido condenados por crimes de menor potencial ou terem aceito uma transação penal, para não responderem ao processo crime. 0 tempo médio de serviço varia de 1 ano e meio a 2 anos. Ainda de acordo com o documento, o índice de reinclusão no programa, ou seja, de reincidência, é de $4,7 \%$. O mesmo índice é de $60 \%$ no regime fechado. ${ }^{85}$

Segundo dados de 2007 da SAP, 20,1 \% dos condenados à prestação de serviços à comunidade eram negros (pretos e pardos). No mesmo período, pesquisa levada a campo pela FGV constatou que 35,78 dos presidiários do

\footnotetext{
${ }^{85}$ Fonte: O Estado de São Paulo, caderno metrópole dia 27 de Outubro de 2008.
} 
Estado eram negros. Se tomarmos como medida de comparação a constituição da população do Estado que segundo o PNAD divulgado em 2007 é constituída em $31 \%$ de negros (pretos e pardos). Podemos perceber uma super representação de $4,78 \%$ entre os encarcerados e uma sub-representação de $15,68 \%$ entre os apenados com medidas alternativas ao encarceramento no Sistema Criminal Paulista.

É a partir destas construções teóricas e dos dados disponibilizados pelas Agências Estatais de pesquisa que percebemos um possível desvirtuamento de uma política de Direitos Humanos dentro da lógica do que o professor Nilo Batista. denominou de caráter "dupla face" do nosso modelo atual ${ }^{86}$ de controle social no Brasil. Ele afirma que em função desse traço consumidores têm alternativas à privação de liberdade como a transação penal e a suspensão condicional do processo ( 2004, p.113), enquanto outros são ainda mantidos encarcerados longe da sociedade por representaram um perigo nas relações cotidianas para a ordem desejada e idealizada para o país.

Essa crítica do professor Nilo Batista aponta a direção que nos leva a concluir que o nosso Jovem Estado Democrático de Direito ainda convive nas suas instituições com esses valores que terminam por revelar as contradições e legados de uma colonização patriarcalista e racista, somados a um longo período ditatorial.

O Sistema Penal não destoa das outras instituições nacionais e, a partir do passado que apresentamos no capítulo anterior busca, informado pelos novos valores cidadãos da Constituição de 88, repensar a nossa política criminal, alterando a estrutura da instituição e dos membros desta.

Escolhemos exemplificar tal limitação a partir dos dados disponibilizados pela Secretaria de Administração Penitenciária sobre o programa de Medidas Alternativas à pena de prisão porque vemos esse espaço, o sistema criminal, como interessante e rico "lócus" de análise da inserção dos valores de Direitos Humanos em que notoriamente todos, historicamente no Brasil $^{87}$,não são iguais,

${ }^{86}$ O professor Nilo Batista classifica o nosso modelo de sistema penal como sistema penal do capitalismo tardio, ele identifica na história do país três modelos anteriores os quais seriam o colonial-mercantilista, imperial-escravista e o republicano positivista. (BATISTA, 2004, p.105)

${ }^{87}$ De ahí, que generalizando los derechos humanos no puedan ser comprendidos fuera de los contextos sociales, económicos, políticos y territoriales en los que, y para los que, se dan. (Artigo, p.21) 
como os dados apresentados no capitulo três demonstraram, assim, observando tais dados como afirma Joaquim Herrera podemos perceber que :

"Los derechos humanos, como cualquier producto cultural que manejemos, son producciones simbólicas que determinados grupos humanos crean para reaccionar frente al entorno de relaciones en los que viven. Por tanto, es una grave irresponsabilidad hacer análisis neutrales de los mismos. Confundiendo "neutralidad" con seriedad científica. Los derechos humanos, si queremos acercarnos a ellos desde su intrínseca complejidad, hay que entenderlos, pues, situados en un marco, en un contexto, en un sistema de valores a partir del cual será más difícil o más fácil su implementación práctica." (2008, p.114)

4. 4 - Possibilidades de intervenção e exemplos de descontrução dos efeitos do racismo estrutural.

Faz parte das recomendações da OEA, quando da apreciação do Caso Simone Diniz, que os profissionais do Judiciário como um todo fossem orientados e educados no sentido de impedir que as práticas de racismo institucional continuassem a se reproduzir em nossas instituições principalmente no sistema co-responsável por cerceá-las: o judiciário. A relatora pautou isso em seu relatório ao dizer que:

"os Estados devem assegurar, em seu ordenamento jurídico interno, que toda a pessoa tenha acesso, a um recurso simples e efetivo que a ampare na determinação de seus direitos, sem discriminação.(...) a omissão das autoridades públicas em efetuar diligente e adequada persecução criminal de autores de discriminação racial e racismo cria o risco de produzir não somente um racismo institucional, onde o Poder Judiciário é visto pela comunidade afrodescendente como um poder racista, como também resulta grave pelo impacto que tem sobre a sociedade na medida em que a impunidade estimula a prática do racismo".

E concluiu dizendo que : 
(...) "é' de fundamental importância estimular uma consciência jurídica capaz de tornar efetivo o combate à discriminação racial e ao racismo pois o poder judiciário de um pais deve ser um sistema de uso eficaz porquanto é instrumento imprescindível no controle e combate à discriminação racial e do racismo".

Recomendando por fim que é necessário

"Organizar Seminários estaduais com
representantes do Poder Judiciário, Ministério Público e
Secretarias de Segurança Pública locais com o objetivo
de fortalecer a proteção contra a discriminação racial e
o racismo". (CIDH, 2006)

É necessário no Brasil que os profissionais do sistema de justiça não sejam mais formados sob a égide das tradições elitistas e clichês e estereótipos deixados por nosso passado autoritário e do período ditatorial.

A remoção desses "resquícios" autoritários das nossas instituições de controle é um dos requisitos básicos para que as atuações sejam menos mitificadas e mais comprometidas com a realidade atual ao invés de serem instrumentos para reprodução dos vícios históricos.

Por exemplo: seguir os exemplos de ensino sobre Direitos Humanos, e levando a temática racial necessariamente com essa formação para agentes do Estado, principalmente os do judiciária, polícias, promotores, Juizes e Servidores.

Declaradamente demonstrar a verdadeira natureza das instituições Estatais e porque foram criadas, reconhecendo que os vícios de formação, resultantes do fato de que estas foram idealizadas por pessoas também podem ser retirados destas instituições quando seus gestores e membros com poder para tal, comprometerem-se com essa transformação. (Herrerara, 2008, p. 19)

Assim, os profissionais do judiciário, que entendem as práticas de racismo, como naturais ${ }^{88}$, o que implica, por exemplo, nos casos de racismo institucional como o Caso Simone Diniz, não encararão tais valores, que naturalizaram o racismo como normais, e não os reproduzirão, o que permite a nós acreditar que

\footnotetext{
88 "Ofender uma pessoa afro-brasileira com as expressões mencionadas na inicial não seria racismo, pois 'brancos' ou 'amarelos' também podem ser prostitutas, maloqueiras, fedidas, galinhas, vagabundas parecidas com macacos (nossos ancestrais) e também $c_{-}{ }_{-} r$ na entrada ou na saída.(...) ".."Os de pele mais escura são ídolos dos mais claros no esporte na música sendo que as mulheres popularmente chamadas de 'mulatas' parece que têm orgulho dessa situação e exibem-se com grande sucesso em muitos locais da moda e da fama.Julgo a denúncia totalmente improcedente para absolver a acionada".(Trechos do Relatório da Sentença do juiz Miguel de Campos Petroni, da $8^{\circ}$ a Vara Criminal da Capital de São Paulo).
} 
resultará na não manifestação de concepções racistas em outros aspectos que esperam neutralidade racial do judiciário a exemplo dos julgamentos, abordagem policial, entre outros exemplos.

Partindo da idéia crítica de que em determinadas sociedades multiculturais como a brasileira o racismo é a regra e não a exceção das relações cotidianas, fazendo com que as práticas de discriminação racial sejam difíceis de serem reconhecidas e identificadas, a aplicação de regras e normas bem como valores universalistas, que menos de Universais e mais de superioridade branca têem, ignoram as condições diferenciadas dos negros, índios entre outros grupos, nessas sociedades.

Essas aplicações normativas apenas conseguem interferir reduzindo, ou até eliminando, as formas mais explícitas de racismo, mas não as cotidianas que permitem estruturas de desigual fruição de bens e direitos a exemplo dos números que levantamos referentes à aplicação do programa de Penas Alternativas no Estado de São Paulo entre outros dados estatísticos oficiais levantados pelo PNUD, IPEA entre outros órgão.

Perceber que para algumas pessoas que fazem identificação os negros são todos "muito parecidos", lembrar que existe uma construção racista na atuação policial, e outros elementos sutis que implicam em desvantagem dos negros quando "ingressam" no sistema criminal é algo relevante de ser considerado pelos julgadores e por isso apresentado durante as suas formações nas escolas de magistratura, do ministério público e nas academias de polícia. Essas políticas afirmativas para qual os valores universalistas do Devido processo legal, Ampla defesa e estado de inocência não são suficientes para neutralizar a desigualdade sociais constatada devem ser trazidas conscientemente pelos formadores.

Em uma realidade como a brasileira, em que a pobreza e o vale social jogam-nos entre os países mais desiguais do mundo, o posicionamento de exigir que a questão racial faça parte das políticas públicas não implica em negar o potencial de alcance das políticas de governo que bucaram mitigar as desigualdades sociais, tentando universalizar o acesso a Direitos Fundamentais, como saúde, educação e devido processo legal. Ao chamar a atenção para a desigualdade, pontua-se a necessidade de políticas específicas para eficaz redução das desigualdades nacionais, pois entendemos como JACCOUD que: 
" cabe chamar a atenção para o papel relevante, apesar de limitado, que têm a cumprir as políticas universais no campo da construção da igualdade racial no Brasil. Como o Ipea tem mostrado em seu trabalho de acompanhamento das políticas sociais, na vigência da Constituição de 1988, as políticas universais educação, saúde, previdência e assistência social - têm tido um papel importante na melhoria das condições de vida da população negra no país. Entretanto, como já foi tratado no capítulo anterior, a implementação das políticas universais demonstra-se insuficiente na busca de uma maior eqüidade entre brancos e negros no país." (JACCOUD, 2008, p.160).

Não é possível universalizar Direitos Humanos sem uma teoria que pense sua aplicação a partir do impuro, isto é, do contexto em que essa universalização é perseguida e quais elementos do ambiente podem desvirtuar essas ferramentas de busca. A elaboração de Políticas Publicas deve ter sempre esse elemento, o impuro, como vetor afim de não incidir em uma prática que busca universalizar, mas que em si é excludente em razão dos vícios contextuais e estruturais que impedem a eficaz aplicação com alcance universal dos Direitos garantidores da dignidade humana.

Theodoro aponta que :

"A ação governamental tem se estruturado em torno do problema da desigualdade racial ou do objetivo da promoção da igualdade racial. Contudo, a desigualdade racial, antes de ser o problema em si, é o resultado de processos diversos, nos quais o racismo e seus desdobramentos, o preconceito e a discriminação, destacam-se como fontes primárias. Combater as desigualdades raciais sem enfrentar suas causas parece apontar para uma ação de limitada eficácia, senão fadada ao insucesso. Estudiosos do tema apontam para a importância de se determinar os fatores causais no desenho e na formulação das políticas públicas. Nesse sentido, o enfrentamento do tripé racismopreconceito-discriminação precisa vir a se constituir no cerne da política de promoção da igualdade racial. Mas, na prática, ainda se verificam alguns obstáculos nesse âmbito, refletindo-se em dificuldades na inclusão da temática racial no rol das ações, políticas públicas, inclusive no que se refere ao cumprimento da própria legislação em vigor. (THEODORO, 2008, p.171) O combate à problemática racial não será efetivo se não lograr uma mudança da mentalidade ainda largamente implantada em nosso país. Sem a efetiva importância da igualdade como valor, o reconhecimento da diversidade na formação nacional, e a condenação de racismos e preconceitos, nem a legislação em 
vigor será aplicada em sua plenitude, nem as políticas e ações de promoção da igualdade racial poderão ter o sucesso que delas se espera." (THEODORO, 2008,p.172).

Nos Estados Unidos, a Escola Critica Racial traz exemplos de como o racismo, definido como regra das relações cotidianas naturaliza determinadas condutas nos julgamentos o que resulta em desvantagens de acesso aos grupos minoritários racialmente, à exemplo da teoria do livro de Cinthya Lee. ${ }^{89}$

Uma Juíza Federal norte - americana, valendo-se das informações que possuía sobre a maior condição de fragilidade a que jovens negros estão submetidos na persecução policial, e da perniciosidade que a condenação por um crime não doloso e violento poderia resultar, mesmo em face dos antecedentes criminais do jovem, que eram todos relacionados a infrações de trânsito, partiu da premissa de que naquela localidade os motoristas negros são mais perseguidos e abordados pela polícia por constituírem um perfil estereotipado, mais sujeito a abordagem violenta policial, e com um raciocínio consciente e crítico optou por não condenar o jovem que julgava à pena de prisão. ${ }^{90}$

No Brasil, não diferente dos EUA a Comissão Interamericana de Direitos Humanos ressaltou o que essa Juíza usou como premissa no seu julgamento que:

"a violência policial no Brasil vitimiza desproporcionalmente pretos e pardos. A Comissão tomou conhecimento que no Brasil, o perfil racial determina um alto número de detenções ilegais e que a população negra é mais vigiada e abordada

\footnotetext{
${ }^{89}$ Cynthia Lee's book, Murder and the Reasonable Man, explains how this works in the area of selfdefense and other defenses that turn out to be much more helpful to straight white males who, for example, shoot and kill another guy in a homosexual panic than they are to a gay or lesbian person. She also recounts the story of an innocent Asian teenager, Yoshihiro Hattori, who went to the wrong suburban house in Louisiana with a friend looking for a Halloween party. The homeowner, believing he was about to be attacked by a scary Asian martial arts expert, shot and killed him. At the trial, the suburban white jury acquitted the homeowner, inding that his fear was reasonable and that he acted in self defense although Hattori had done nothing that any of us would find threatening. Lee's pioneering exploration of white normativity needs to be extended to a host of other areas, criminal as well as civil. (Delgado \& Stefancicc, 2005, p.16)

${ }^{90}$ Federal judge Nancy Gertner applied a milder version of Butler's theory of jury nullification when she refused to apply a three-strikes-and-you're-out recidivist sentencing law to a black defendant in Massachusetts, who had just been convicted of his third offense.39 Because his two prior convictions had been automobile-related, and taking judicial notice of how black motorists are frequently subjected to police profiling and suspicion, so that those two prior convictions could easily have been the product of racism, Judge Gertner refused to apply the three-strikes law and sentenced him, instead, to the shorter sentence of a non-recidivist first or second offender. (Delgado \& Stefancicc, 2005, p.16)
} 
pelo sistema policial, sendo esse tema objeto de recomendação pela Comissão não somente em relatório geral sobre o país mas também em relatório de mérito." (CIDH, 2006).

O comportamento dessa Juíza federal Americana é a expressão do tipo de compreensão necessária aos profissionais que instrumentalizam o Direito.

O judiciário brasileiro é um exemplo de instituição dominada por brancos, numa tradução ao pé da letra de White Dominated Institution. No caso, a instituição é formada em sua maioria por pessoas de ascendência branca sendo os detentores do poder de decisão quase todos brancos. Essa ausência de diversidade limita a possibilidade de compreensão e soluções aos problemas que esses profissionais se encontram, pois as suas compreensões de mundo são iguais, e estes não são apresentados a posições e soluções diversas e diferentes.

Seja Juiz ou promotor este irá se deparar com situações inusitadas que demandarão soluções caso a caso, essa é a realidade que o programa de políticas de penas alternativas, assim como o processo penal ordinário apresenta à profissionais que não conseguem adaptarem-se, por falta de sensibilização e preparação à elas.

A Comissão interamericana de Direitos Humanos quando da analise do Caso Simone Diniz afirmou que "Da prova testemunhal, passando pelo inquérito na polícia até a decisão do Judiciário, há preconceito contra o negro. Os três níveis são incapazes de reconhecer o racismo contra o negro". (CIDH, 2006).

Essa incapacidade de reconhecer o racismo, somada as práticas cotidianas de racismo não percebidas como tais, resultam nos desigual desfrute dos possíveis benefícios que as políticas publicas de Direitos Humanos poderiam resultar no país.

Conforme pontua a professora Íris M Young, apesar de as práticas institucionalizadas que perpetuam as injustiças Estruturais não permitirem que se culpeuma ou pessoas em específico pelos resultados dessas interações, ainda assim não há como eximir a contribuição e conseqüente responsabilidade de todos para com as práticas que perpetuam ${ }^{91}$ e necessária participação e

\footnotetext{
${ }^{91}$ When harms result from the participation of thousands or millions of people in institutions and practices that produce the unjust results, on the other hand, such an isolating concept of
} 
comprometimento de todos para a eliminação dessas injustiças estruturais que terminam por infiltrarem-se em espaços que idealmente deveriam ser eminentemente justos, como os espaços de aplicação de políticas recomendadas pelas Organizações Internacionais de Direitos Humanos, no Brasil.

Alguns apontarão que sendo o programa de medidas alternativas à pena de prisão, em si, um desafio, num país de tradições autoritárias, criticá-lo é um desserviço, uma vez que não existe outra proposta para aplicar em seu lugar. No entanto, pontuamos que a crítica não é à salutar proposta de redução ou até mesmo eliminação do número de encarcerados no país, o que buscamos pontuar é que a lógica racialmente estruturada da sociedade brasileira, inviabiliza, sempre que o elemento racial não é "colocado no mesa" (expressão da Escola Crítica Racial). A cegueira racial impede a universalização de meios que viabilizem o acesso aos bens necessários à persecução de uma vida digna, ou da emancipação humana, como disse Marx ou da persecução do projeto pessoal como coloca Kant.

È importante destacar que ao reconhecermos que as nossas instituições podem estar ou estão eivadas de valores ficcionais e não reais não implica em desvalorizar a natureza desta com suas técnicas e instrumentos, mas sim, apontar possíveis limitações e com isso buscar práticas mais eficientes, que permitam que elas alcancem seus reais objetivos declarados.

É por essa razão que apesar de aparentemente contraditório propormos a aplicação de valores pautados em Direitos Humanos, mesmo em face da crítica a forma como os Direitos Humanos são teorizados e aplicados em alguns contextos, não é contradição.

Acreditamos, sim, que o espaço de teorização crítico dos Direitos Humanos, em que são instrumentos de proteção dos oprimidos em face das ordens dominantes, ainda é um lócus profícuo para a produção de teoria e prática de combate ao racismo no Brasil e no mundo.

Por isso entendemos importante colocar, em evidência as limitações e vícios que essas instituições trazem por terem sido criadas por seres humanos,

responsibility is inadequate. Where there are structural injustices, finding that some people are guilty of perpetrating specific wrongful actions does not absolve others whose actions contribute to the outcomes from bearing responsibility (YOUNG, 2004, p.20). 
que podem modificá-las para que elas atendam aos seus objetivos declarados, se tiverem em si vontade, consciente, para tal mudança.

Assim, as políticas pautadas em valores protetores da dignidade da pessoa humana podem, sim, serem efetivas, caso determinadas contradições sejam atentamente observadas e sanadas. Acreditamos que somente com a atuação conjunta, população, judiciário e universidade é que alguns padrões discriminatórios que implicam em uma redução do usufruto da dignidade entre os afro descendentes no Brasil, deixarão de existir ou ao menos, de passarem desapercebidos sob o manto da crença na Democracia Racial. 


\section{Considerações Finais.}

Super representados nos presídios e sub-representados nos programas de medidas alternativas à pena de prisão é assim que os negros aparecem nos dados oficiais. Essas estatísticas trazem algumas possibilidades de interpretação sobre a realidade racial e lógica de funcionamento do nosso sistema criminal.

Seriam os negros propensos a cometerem crimes mais violentos, não sendo assim abarcados pelos privilégios oferecidos pelos programas de medidas alternativas a pena de prisão ou as penas alternativas, uma vez que não trazem consigo o requisito de terem cometidos crimes de menor potencial ofensivo?

Teria esse grupo uma tendência, predisposição, para a criminalidade? O que os impediriam de valerem-se dos privilégios conferidos aos autores de condutas típicas de pequeno potencial ofensivo, sem antecedentes criminais. A partir dessa teses a maioria dos negros que cometem infrações possuiriam, sempre, algum antecedente criminal não podendo desfrutar dos benefícios da primariedade quando do cometimento de infrações de menor potencial ofensivo.

Ou, abraçando um viés Criminológico Crítico e de Direitos Humanos Críticos, os negros não seriam contemplados pelos privilégios das políticas públicas de Direitos Humanos no sistema penal da mesma forma como ocorreria em outros espaços nos quais são implementadas políticas públicas estatais de Direitos Humanos as quais não julgam como relevante pautar o elemento racial na sua teoria e prática?

O Racismo, impregnado nas nossas relações cotidianas, que inviabiliza o eficaz gozo dos Direitos Fundamentais Constitucionais no Processo Penal para negros, também inviabilizaria as outras políticas públicas de Direitos Humanos para os "clientes" negros do sistema penal? 
A dimensão propriamente desconstrutora, consubstanciada pela crítica historiográfica, sociológica e criminológica do moderno sistema penal abarca no Brasil, sem maiores problemas, a categoria raça. No entanto, é na dimensão das políticas criminais

alternativas e dos movimentos de reforma, que somente puderam ser pensadas a partir desta desconstrução que o racismo institucional, perceptível no perfil e na cegueira racial, manifesta-se. Essas novas concepções de justiça tornam-se inexistentes para os negros brasileiros que, sempre que encontram-se no sistema penal, deparam-se com a construção positiva que estruturou e ainda estrutura o Sistema Penal para estes.

O interessante é constatar, por meio dos dados oficiais levantados, ao analisarmos a intervenção dos programas de Direitos Humanos no sistema penal, que o que temos por resultado não é a alteração estrutural de uma realidade, mas sim, o uso de tais mecanismos humanistas para a manutenção de uma lógica colonial. Nela a cadeia permanece como um espaço reservado para grupos sociais específicos, os quais já foram identificados e tiveram os seus lugares sociais definidos desde o início do projeto de nação e sociedade brasileira.

O programa de medidas alternativas à pena de prisão termina por apresentar-se não como uma proposta do Estado para redução do número de encarceramentos, mas sim como uma resposta à demanda social por redução da impunidade. Isso teve por conseqüência a ampliação do número de pessoas atingidas pelo controle social, tornando-se necessário reduzir a seletividade durante a persecução penal, deslocando - $a$, com os seus mesmos valores $\mathrm{e}$ funções, para um outro ponto do sistema de controle social: a execução da pena.

Entendemos que não há que se pensar, com o objetivo de uma intervenção com resultados de longa duração em políticas temporárias com o fim de reparação. Eles são uma resposta emergencial a uma situação gritante de desigualdade racial no Brasil. No entanto, tais desigualdades apenas deixarão de ser o traço marcante do nosso vale social, quanto em nossas políticas estatais de erradicação da pobreza tivermos reconhecido por parte do Estado esta diversidade étnica e a necessária percepção em todos os projetos de políticas públicas das implicações, limitações e necessidades em face deste contexto. Entendemos que para isso será necessário colocar a temática das raças "em cima da mesa" de negociações, como dizem os teóricos da Escola Crítica Racial, 
evitando que o direito mantenha-se como um instrumento de invisibilização e opressão desses grupos.

Ignorando essas demanda, incidiremos sempre em políticas públicas ineficazes, em seus objetivos declarados, que, ao invés de reduzirem as desigualdades, criam novos tipos, não tão perceptíveis, mas nem por isso menos atentatórios de formas de agressão à Dignidade Humana. 


\section{BIBLIOGRAFIA}

ADORNO, Sérgio. Discriminação Racial e justiça Criminal em São Paulo. Novos Estudos CEBRAP, n43, novembro 1995. P.45-63.

ALBRECHT. Sofia Mentz. A Dignidade da Pessoa Humana Como Fundamento da ordem Constitucional. Tese de Doutorado. São Paulo. Universidade de São Paulo. 2006.

ALVAREZ, Marcos César. Bacharéis, criminologistas e juristas: saber jurídica e nova escola penal no Brasil. São Paulo: Método, 2003.

ANDRADE, Vera Regina Pereira de. Do paradigma etiológico ao paradigma da reação social: mudança e permanência de paradigmas criminológicos na ciência e no senso comum. in Revista Brasileira de Ciências Criminais, São Paulo, Instituto Brasileiro de Ciências Criminais, n. 14, p. 276-287, abr./jun./96.

- Dogmática e Sistema Penal: Em Busca da Segurança Jurídica Prometida. Tese UFSC. 1994, Florianópolis.

ANDREWS, George Reid. Negros e brancos em São Paulo(1888-1988), EDUSC, 1998, 444p.

ANYIAR DE CASTRO, Lola. Criminologia de la liberación. Maracaibo: Universidade de Zulia, 1987.

AZEVEDO, Célia Maria Marinho de. Onda Negra Medo Branco: o negro no imaginário das elites do século XIX. Rio de janeiro: Paz e Terra, 1987.

BARATTA, Alessandro. Criminologia Crítica e Crítica do Direito Penal. Freitas Barros Editora, 1999, 239p.

BATISTA, Nilo. In . O Negro e o Direito. Coleção, vol 3. OABRJ Debate. Rio de Janeiro, Agosto, 1984.

Novas Tendencias do Direito Penal. Rio de Janeiro: Renavan,

2004.

BENTO, Maria Aparecida S. Pactos narcísicos no racismo: branquitude e poder nas organizações empresariais e no poder público. Tese (Doutorado em 
Psicologia Social) - Programa de Pós-Graduação em Psicologia da Universidade de São Paulo, 2002

BRANDÃO, Adelino. Direito Racial Brasileiro: teoria e prática. São Paulo: Editora Juarez de Oliveira , 2002. 200p.

CALHAU, Lélio Braga. Algumas considerações sobre o funcionalismo e o Direito Penal no Brasil. Disponível na Internet: http://www.direitopenal.adv.br

CAPPELLETTI, Mauro. GRANT, Bryant. Acesso à justiça. Tradução de Ellen Grace Northfleet. Porto Alegre: Sergio Aantonio Fabris Editor, 1988.

CASTIGLIONE, Teodolindo. Lombroso Perante a Criminologia Comtemporânea. São Paulo, Edt. Saraiva, 1962. 295 p.

CIDH, relatório n 66/06 - caso 12.001. 21 de Outubro de 2006, disponível em : http://www.cidh.org/annualrep/2006port/BRASIL.12001port.htm. Acesso em 09 de janeiro de 2009.

COLE, David. No Equal Justice : Race and Class in the American Criminal Justice System. Nova York edt. New Press, 1999. 218p.

COMPARATO, Fábio Konder. A afirmação histórica direitos humanos, 3.ed., São Paulo: Saraiva, 2003.

CORACINI, Celso Eduardo Faria. A Antropologia Criminal no Brasil Nas obras de Candido Nogueira da Motta e Raimundo Nina Rorigues. Revista Brasileira de Ciências Criminais, São Paulo, Instituto Brasileiro de Ciências Criminais, n. 41, p. 179-205, abr./jun./96.

DA SILVA, Jorge. Violência e racismo no Rio de Janeiro. Rio de janeiro: Editora da Universidade Federal Fluminense. 2ed. 2003.

DALLARI, Dalmo. Policiais, Juizes e Igualdade de Direitos. In O Preconceito, vários autores, São Paulo, Edusp. 1996. P. 87-113.

DARMON, Pierre. Médicos e Assassinos na Belle Epóque: A Medicalização do Crime. Rio de Janeiro, edt. Paz e Terra, 1991. p.310

DIAS, Jorge de Figueiredo; ANDRADE, Manuel da Costa. Criminologia: O Homem delinqüente e a sociedade Criminógena. $2^{\mathrm{a}}$ reimpressão, Coimbra, Coimbra Editora, 1997. 573p. 
DUARTE, Evandro Charles Duarte Piza. Criminologia e Racismo: Introdução à Criminologia Brasileira. São Paulo: Editora Juruá, 2002. 290p.

DURBAN. II Conferência Mundial de Combate ao Racismo, Discriminação Racial, Xenofobia e Intolerância Correlata. Declaração de Durban e Plano de Ação. Tradução e edição em língua portuguesa pela Fundação Palmares. Ministério da Cultura. Brasília (DF), 2001.

ECONOMIDES, Kim. Lendo as Ondas do Movimento de acesso a Justiça: epstemologia versus metodologia? In: PANDOLFI, Dulce Chaves et al (Orgs). Cidadania, Justiça e violência. Rio de Janeiro, Fundação Getulio Vargas, p. 6176.

FALCÃO, Valdirene Ribeiro de Souza. O Papel da Dignidade da pessoa Humana na Constituição de 1988. Dissertação de Mestrado. São Paulo. Universidade de São Paulo. 2006.

FERNANDES, Fernando Andrade. O Processo Penal Como Instrumento de Política Criminal. Coimbra. Almedina, 2001. 866p.

FERREIRA, Ricardo Flanklin. Afro-descendente: Identidade em Construção. São Paulo: EDUC; Rio de Janeiro: Pallas, 2000.

FINEMAN, Martha Albertson. The New Tokenism. In Vermont Law Review, volume 23, p.289-296, 1998.

FONSECA, Guido. Crimes, criminosos e a criminalidade em São Paulo. (1870 1950) Edt. Resenha Tributária ,1988,. P.363

FRYE, Marilyn, in The Politics of Reality: Essays in Feminist Theory (Trumansburg, N.Y.,: The Crossing Press, 1983).

GARCIA-PABLOS DE MOLINA, Antônio. Criminologia. 2 ed. Ver. Atual. E ampl. , São Paulo, Editora Revista dos Tribunais, 1997. 520p.

GARRIDO, V; STANGELAND,P; REDONDO,S. Pincipios de Criminología., Valência, Tirant lo Blanch, 1999.

GIL, Antonio Carlos. Métodos e técnicas de pesquisa social. 4 ed. São Paulo : Atlas, 1996. $208 \mathrm{p}$ 
GRANT-THOMAS, Andre e POWELL, John A. Toward a Structural Racism Framework in Poverty \& Race : Poverty \& Race Research Action Council Novembro/Dezembro de 2006 volume 15: numero 06 pag 03-06

GUIMARÃES, Antonio Sergio Alfredo. 2002. Classes, Raças e Democracia. São Paulo, Editora 34.

GUIMARÃES, Antônio Sérgio Alfredo. Raça e os Estudos de Relações Raciais no Brasil. Novos Estudos CEBRAP, n54, julho 1999. P.147-156.

GUIMARÃES, Antonio Sergio Alfredo. Racismo e anti-racismo no Brasil. 1ª. ed. São Paulo: Editora 34, 1999.

HÄBERLE, Peter. A dignidade humana como fundamento da comunidade estatal, in SARLET, Ingo Wolfgang (org.). Dimensões da Dignidade: Ensaios de Filosofia do Direito e Direito Constitucional, $1^{\mathrm{a}}$ Edição, Porto Alegre: Editora Livraria do Advogado, 2005, pp. 89-152.

A Eficácia dos Direitos Fundamentais. 6.ed. rev. atual e ampl., Porto Alegre: Livraria do Advogado, 2006.

HASENBALG, Carlos . Entre o mito e os fatos: racismo e relações raciais no Brasil. In: DADOS: Revista de Ciências Sociais. Rio de Janeiro: v.38, 1995, p.355-374.

HERRERA FLORES, Joaquín. Hacia una visión compleja de los derechos humanos. In: [coord.].El vuelo de Anteo: derechos humanos y crítica da la razón liberal. Bilbao: Desclée, 2000. p. 19-78 . Los derechos humanos como productos culturales.Madrid: Catarata, 2005. .La complejidad de los derechos humanos - bases teóricas para una redefinición contextualizada. In: revista internacional de direito e cidadania, $n$. 1, p. 103-135, junho/2008

HIGHSMITH, Gary. Black Skin, White Justice: Race Matters in the Criminal Justice System. Yale University, United Estates. Disponível em: <http://www.yale.edu/ynhti/curriculum/units/1996/1/96.01.10.x.ht>. Acesso em 17 Maio 2002. 
HOUAISS, Antônio e VILLAR, Mauro de Salles. Dicionário Houaiss da língua portuguesa. Rio de Janeiro, Objetiva, 2001.

IKAWA, Daniela Ribeiro. Concepção de ser humano e direito à redistribuição: o caso da ação afirmativa". Tese de Doutorado. São Paulo. Universidade de São Paulo. 2006.

JACCOUD , Luciana. O combate ao racismo e à desigualdade: o desafio das políticas públicas de promoção da igualdade racial In. As políticas públicas e a desigualdade racial no Brasil : 120 anos após a abolição / Mário Theodoro (org.), Luciana Jaccoud, Rafael Osório, Sergei Soares . - Brasília : Ipea, 2008. p. 131-166.

KAHN, Túlio. Ensaios Sobre Racismo. Manifestações Modernas do Preconceito na Sociedade Brasileira. São Paulo, edt. Conjuntura, 2000.

KANT, Immanuel. Fundamentação da Metafísica dos Costumes. Lisboa, Edições 70, 2005.

KENSKI, Rafael. Vencendo na Raça. Revista Superinteressante. Abril , 2003. P.42-49.

KLOEPFER, Michael. Vida e dignidade da pessoa humana, in SARLET, Ingo Wolfgang (org.). Dimensões da Dignidade: Ensaios de Filosofia do Direito e Direito Constitucional, $1^{\mathrm{a}}$ Edição, Porto Alegre: Editora Livraria do Advogado, 2005, pp. 153-184.

LOMBROSO, Cesare. L'uomo Delinquente. In rapporto all'antropologia, alla giurisprudensa ed alle discipline carcerarie. $1^{\mathrm{a}} \mathrm{Ed}$. Napoleone editore, Roma.

L'uomo Delinquente. In rapporto all'antropologia, alla giurisprudensa ed alle discipline carcerarie. Vol primo, Delinquente Nato e Pazzo Morale. 4 ${ }^{\mathrm{a}}$ Ed. Bocca Editore, Torino. 1889

O Homem Criminoso. Trad. de Maria Carlota Carvalho Gomes. Rio de Janeiro: Editora Rio, Edição histórica.

LOPES, José Reinaldo de Lima. Direitos Humanos e Tratamento Igualitário: questões de impunidade, dignidade e liberdade. In Revista Brasileira de Ciências Sociais, vol. 15, n.42. Fev. 2000. pp. 77-100. 
O Direito ao Reconhecimento para Gays e Lésbicas. In SurRevista Internacional de Direitos Humanos. Ano2, n.02. 2005. pp. 65-96.

LÖSCHPER, Gabi (2000, January). Crime and social control as fields of qualitative research in the social sciences_[12 paragraphs]. Forum Qualitative Sozialforschung / Forum:Qualitative Social Research [On-line Journal], 1(1). Disponível em: http://qualitative-research.net/fqs 08/07/2003

LOURENÇO, Conceição. Racismo a verdade dói: Encare Mosntrando. São Paulo, Editora Terceiro Nome, 2006.

MANNHEIM, Hermann. Criminologia Comparada. [Trad] J F Faria Costa ; [Trad] M Costa Andrade, Lisboa, Edt. Fundação Calouste Gulbenkian. Vol. I e II.

MARCHI, Eduardo C. Silveira. Guia de Metodologia jurídica. Edt. Edizioni del Grifo. 2001. Itália.

MARINHO, Cláudia M. Ribas (1999). O Racismo no Brasil - Uma análise do desenvolvimento histórico do tema e da eficácia da lei como instrumento de combate à discriminação racial. Monografia não-publicada. Universidade Federal Santa Catarina.

MASSUNARI, Roberta. Bem Jurídico Penal e Movimentos Políticos Criminais: a valoração do bem jurídico patrimônio. Trabalho de Conclusão de Curso, Franca: UNESP, 2002

MAURER, Béatrice. Notas sobre o respeito da dignidade da pessoa humana... ou pequena fuga incompleta em torno de um tema central, in SARLET, Ingo Wolfgang (org.). Dimensões da Dignidade: Ensaios de Filosofia do Direito e Direito Constitucional, $1^{\mathrm{a}}$ Edição, Porto Alegre: Editora Livraria do Advogado, 2005, pp. 61-88.

Mclntosh, Peggy. (1990). White privilege: unpacking the invisible knapsack. Independent School, winter, 31-36. Disponível em http://www.feinberg.northwestern.edu/diversity/uploaded docs/UnpackingTheKna psack.pdf. acesso em 10/01/2008.

MEUSER, Michael \& LÖSCHPER, Gabi (2002, February). Introduction: Qualitative Research in Criminology [26 parágrafos]. Forum Qualitative Sozialforschung / 
Forum: Qualitative SocialResearch [On-line Journal], 3(1). Disponível em : http://www.qualitativeresearch.net/fqs/fqs-eng.htm [Data de acesso: 08/07/2003] MONREAL, Eduardo Nova. O Direito como obstáculo à transformação social. Fabris editora. Porto Alegre, 1988, 221 p.

MUTUA, Makau. Change in the Human Rights Universe. In: Harvard Human Rights Journal / Vol. 20 p.3-5. 2007.

NEDER, Gislene. Discurso Jurídico e Ordem Burguesa no Brasil. Porto Alegre: Sergio Antônio Fabris Editor, 1995, 168p.

NINO, Carlos. Ética y derechos humanos: um ensaio de fundamentación. Buenos Aires: Astrea, 1989.

ORDEIG, Enrique Gimernat. Conceito e Método da Ciência do Direito Penal . Editora Revista dos Tribunais. São Paulo, 2002, 110p.

Pérez LUÑO, Antonio Enrique. Derechos Humanos, Estado de Derecho y Constitucion. $8^{\mathrm{a}}$ ed. Madrid, Tecnos, 2003.

PIERANGELli, José Henrique. Códigos Penais do Brasil: Evolução Histórica, Bauru, ED. Javoli LTDA, 1980.

PIRES, Ariosvaldo de Campos; SALES, Sheila Jorge Selim de. Alguns Movimentos Políticos Criminais da Atualidade. Revista Brasileira de Ciências Criminais, São Paulo, Instituto Brasileiro de Ciências Criminais, n. 42, p. 295-306, abr./jun./96

PORTANOVA, Rui. Motivações ideológicas da sentença. 3.ed. , Porto Alegre: Ed. Livraria do Advogado, 1997. 173p.

PRUDENTE, Eunice Aparecida de Jesus. Preconceito Racial e igualdade jurídica no Brasil. São Paulo. Julex Livros LTDA. 1989. 281p.

QUINNEY, Richard. Class, State, and Crime Reino Unido, Longman Group $2^{\circ}$ ed. 1980.

RIBEIRO, Carlos Antonio Costa. (1994) "Clássicos e Positivistas no moderno direito penal brasileiro: uma interpretação sociológica". In: HERSCHMANN, Micael M., PEREIRA, Carlos Alberto Messender (orgs.). A Invenção do Brasil 
Moderno: Medicina, Educação e Engenharia nos anos 20-30. Rio de Janeiro: Rocco,1994, p. 130-146.

- Cor e Criminalidade: Estudo e Analise da justiça no Rio de Janeiro (1900-1930). Editora UFRJ. Rio de Janeiro. 1995. 167p.

ROCHA, Cármen Lúcia Antunes. O princípio da dignidade da pessoa humana e a exclusão social. Revista de Interesse Público, Porto Alegre, n. 4, 1999, p.24- 49.

RODRIGUES, Nina, As Raças Humanas e a Responsabilidade Penal no Brasil.Editora livraria progresso. Salvador, 1894.

RODRIGUES, Nina, As raças humanas e a responsabilidade penal no Brasil, Bahia: Imprensa Econômica, 1894

SANTOS, Gislene Aparecida dos. As Luzes e a Representação do Negro no Brasil. Dissertação de Mestrado. FFLCH- Universidade de São Paulo, 1993.

SANTOS,Christiano Jorge. Crimes de Preconceito e de Discriminação Racial , Max Limonad, 2001, São Paulo.

SÃO BERNANRDO, Augusto Sérgio dos Santos de. Identidade Racial e Direito à Diferença Xangô e Thémis. Dissertação de Mestrado, 2006. UNB. Brasília.

SARLET, Ingo Wolfgang. (org.). Dimensões da Dignidade: Ensaios de Filosofia do Direito e Direito Constitucional, $1^{\mathrm{a}}$ Edição, Porto Alegre: Editora Livraria do Advogado, 2005.

SARLET, Ingo Wolfgang. As dimensões da dignidade da pessoa humana: construindo uma compreensão jurídico-constitucional necessária e possível, in SARLET, Ingo Wolfgang (org.). Dimensões da Dignidade: Ensaios de Filosofia do Direito e Direito Constitucional, $1^{\mathrm{a}}$ Edição, Porto Alegre: Editora Livraria do Advogado, 2005, pp. 13-44.

- Dignidade da pessoa humana e direitos fundamentais na Constituição Federal de 1988, 4. ed. rev e atual., Porto Alegre: Livraria do Advogado, 2006.

SARMENTO, Daniel. A Igualdade Étnico-Racial no Direito Constitucional Brasileiro: Discriminação "de facto", Teoria do impacto Desproporcional e Ação 
Afirmativa. In Leituras Complementares de Direito Constitucional. Salvador: Jus Podium, 2006. pp. 115-162.

SCHWARCZ, Lilia Moritz. "Nem Preto Nem Branco, muito pelo contrário: cor e raça na intimidade". In História da Vida Privada no Brasil. Vol 4. Contrastes da intimidade comtemporânea, org. por Lilia Moritz Schwarcz. São Paulo: Companhia das Letras, 1998. P.173-244.

- Ser peça, ser coisa: definições e especificidades da escravidão no Brasil. In: SCHWARCZ, Lilia Moritz e REIS, Letícia V. de Sousa (orgs.). Negras Imagens. São Paulo: Edusp, 1996. pp. 11-29.

. O Espetáculo das Raças: cientistas, instituições e questão racial no Brasil. São Paulo. Companhia das Letras , 1993. 288p.

SEELMAN, Kurt. Pessoa e dignidade da pessoa humana na filosofia de Hegel, in SARLET, Ingo Wolfgang (org.). Dimensões da Dignidade: Ensaios de Filosofia do Direito e Direito Constitucional, $1^{\mathrm{a}}$ Edição, Porto Alegre: Editora Livraria do Advogado, 2005, pp. 45-60.

SHECAIRA, Sérgio Salomão. Racismo. In: Revista de Direitos Difusos. Vol.9, Direitos dos Grupos Vulneráveis, Editora Esplanada-ADCOAS - Outubro, 2001. P.1173-1188.

SHIMABUKURU, Alessandro. Pesquisa Traça Perfil de Criminoso. Tribuna do Direito , Abril de 2001. p.29.

SILVA JR, Hédio. Direito de Igualdade Racial: Aspectos Constitucionais, Civis e Penais: Doutrina e Jurisprudência. São Paulo: Editora Juarez de Oliveira. 2002. $216 p$.

SILVA, José Afonso da. A dignidade da pessoa humana como valor supremo da democracia. In. Revista de Direito Administrativo. Rio de Janeiro, v. 212, abr./jun. 1998. pp.89-94.

TAYLOR, Ian; WALTON, Paul e YOUNG, Jock. Criminologia Critica. tradução de Juaresz Cirino dos Santos e Segio Tancredo Rio de Janeiro Edições Graal, 1980, $302 \mathrm{p}$.

THEODORO,Mário . À guisa de conclusão: o difícil debate da questão racial e das políticas públicas de combate à desigualdade e à discriminação racial no 
brasil. In As políticas públicas e a desigualdade racial no Brasil : 120 anos após a abolição / Mário Theodoro (org.), Luciana Jaccoud, Rafael Osório, Sergei Soares . - Brasília : Ipea, 2008 p.167-176.

TURRA, Cleusa e VENTURI, Gustavo (org.) Racismo Cordial. São Paulo, Ática, Folha de São Paulo/DataFolha, 1995.

VASCONCELOS, Frederico. Pesquisa Revela o Perfil do Ladrão em São Paulo. Folha de São Paulo. 04/03/2000, p. C10.

VERAS, Cristiana Viana. Estudantes Negros e a Transformação das Faculdades de Direito em escolas da Justiça: a Busca por uma maior igualdade. Revista o Negro e a Educação ANPED p.73-100.

VIEIRA JUNIOR, Ronaldo Jorge Araújo, Responsabilização Objetiva do Estado Segregação institucional do negro e adoção de ações afirmativas como reparação aos danos causados. Curitiba: Juruá: 2005

VIEIRA, Oscar Vilhena. Direitos Fundamentais. Uma Leitura da jurisprudência do STF. São Paulo. Malheiros. 2006.

WATANABE , Kasuo. "Acesso à Justiça e sociedade moderna". In GRINOVER, Ada P. et al. Participação e Processo. São Paulo, 1988. 416p.

WILSON, Anna V. Borboletas, pássaros e teias de aranha: Interrogar o privilégio de ser branco por meio da investigação narrativa. In Currículo sem Fronteiras, v.5, n.02, pp 86-100, jul/Dez. 2005.

WOLKMER, Antonio Carlos. A Questão Judaíca e os Direitos Humanos. Seqüência, Florianópolis, n. 48, p. 11- 28, 2004.

YOUNG, Iris Marion. "Taking the Basic Structure Seriously," In Perspectives on Politics (2006), 4:1:91-97 Cambridge Journal University Press.

Responsibility and Structural Injustice. Iris Marion Young. University of Chicago. July 2004 disponível : socpol.anu.edu.au/YoungRespStrInj6.05.doc . Acesso em : 08 de Outubro de 2008. 
. 2005. Structural Injustice and the Politics of Difference. AHRC Centre for Law,Gender, and Sexuality Intersectionality Workshop. 21/22 May, Keele University, UK.

ZAFFARONI, Eugênio Raul. Criminología “Aproximación desde un margen". Vol. I, Bogotá, Editorial Temis S.a, 1988, 267p.

ZAFFARONI, Eugenio Raul. Sistemas penales y derechos humanos en América latina. Buenos Aires: Depalma, 1986 